\title{
TIPPING THE BALANCE
}

Policies to shape agricultural investments and markets in favour of small-scale farmers

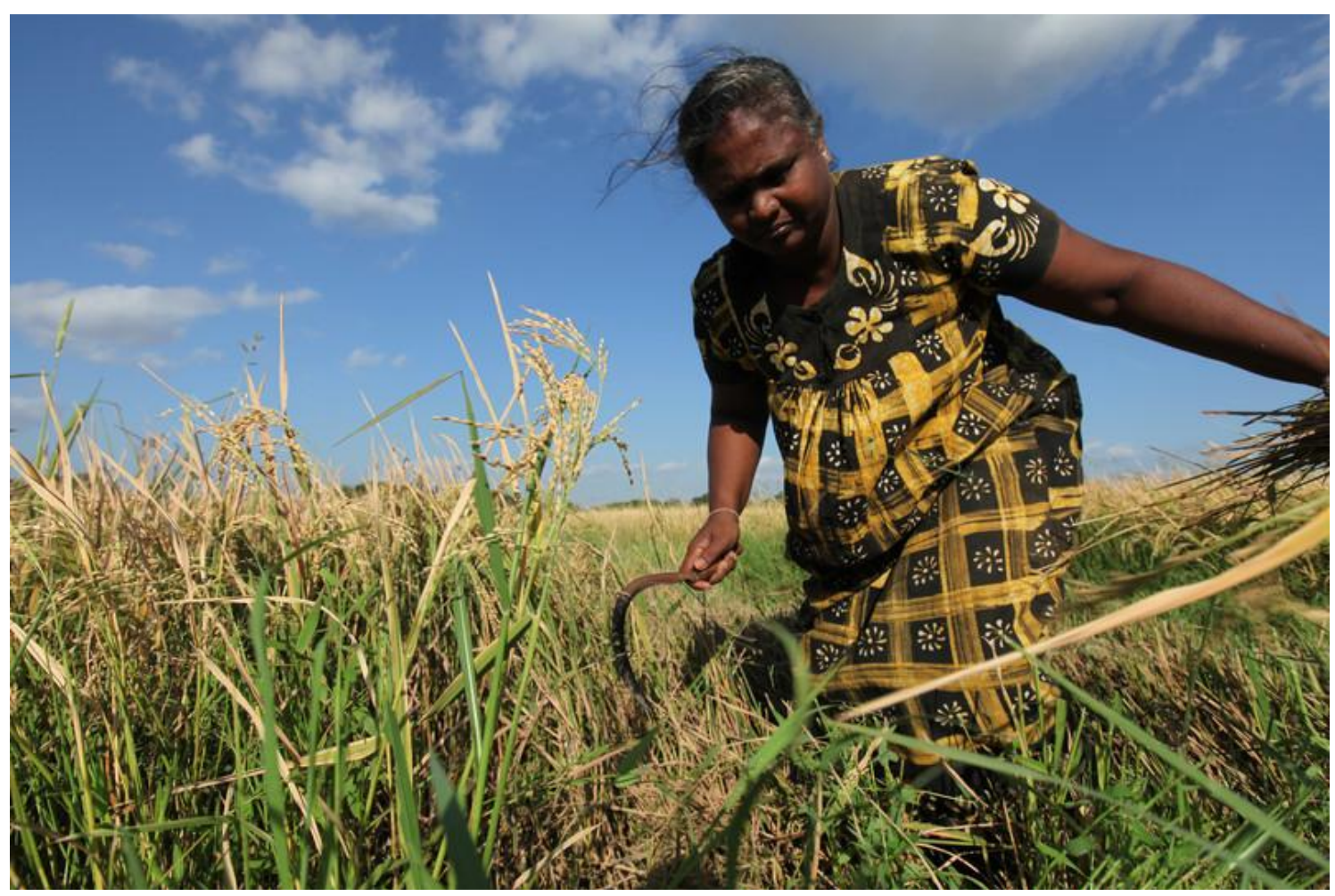

Rasmalar and her family are part of a rice growing co-operative in Sri Lanka (2011). Photo: Abir Abdullah/Oxfam

\section{BILL VORLEY}

PRINCIPAL RESEARCHER, SUSTAINABLE MARKETS GROUP, IIED

\section{LORENZO COTULA}

SENIOR RESEARCHER, NATURAL RESOURCES GROUP, IIED

MAN-KWUN CHAN

INDEPENDENT CONSULTANT

\section{iied




\section{ABSTRACT}

A recent wave of large-scale land acquisitions and other commercial investment in agriculture has raised concerns that small-scale producers are being marginalized. This report takes a new look at the role of public policy and market governance in ensuring inclusive sustainable development. It identifies key policy levers and how these tip commercial investments in favour of either small- or large-scale farming, and how policy levers influence market governance to constrain or support the fair sharing of risk and reward between small-scale producers and the rest of the market. A considerable proportion of the report is dedicated to identifying policy elements that can specifically contribute to gender-equitable results. The focus of the analysis is on national policy, with international policy discussed insofar as it affects national policy and investment processes. The work was supported by four country case studies, conducted in Guatemala, Nigeria, Tanzania and the Philippines.

\section{ACKNOWLEDGMENTS}

The authors would like to thank all authors of the four country reports, including Guillermo Díaz (Guatemala), Larry Digal (Philippines), Prosper Ngowi (Tanzania), and Ade Olomola (Nigeria). Thanks also go to the Oxfam country staff who managed the country reports and contributed so much to this report, including Kalayaan Constantino, Golda Hilario, Edmund Matotay, Celeste Molina, and Abdulazeez Musa.

Jodie Thorpe commissioned this report and Maria Michalopoulou managed its delivery. Production was managed by Anna Coryndon. Oxfam would also like to acknowledge David Bright and Michele Bruni, who came up with the initial concept, and Sally Baden, Stephanie Burgos, Lies Craeynest, Alan Doran, Penny Fowler, Kate Geary, Thalia Kidder, Liz Kirk, Monique Mikhail, Duncan Pruett, Jo Rowlands, Erinch Sahan, Hugo Sintes, and Suzanne Zweben for their role reviewing the report. IIED would like to acknowledge David Hebditch and Emily Polack for supporting the research.

\section{The authors}

Bill Vorley is Principal Researcher in the Sustainable Markets Group at IIED.

Lorenzo Cotula is Senior Researcher in the Natural Resources Group at IIED, where he leads work on land rights and on natural resource investment.

Man-Kwun Chan is an independent consultant specialising in gender, labour and smallholder issues in global supply chains.

The research for this report was part-funded by UK aid from the UK government, and by the European Union. However, the views expressed in this report do not necessarily reflect the views of the UK government or the EU.
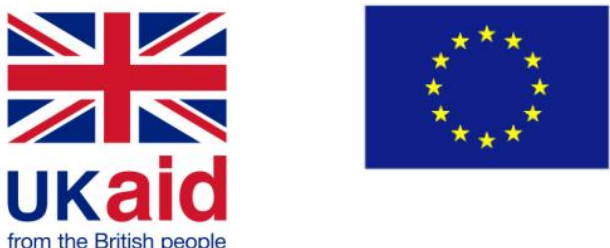


\section{CONTENTS}

$\begin{array}{ll}\text { Acknowledgments } & 2\end{array}$

$\begin{array}{ll}\text { Foreword } & 4\end{array}$

Executive summary $\quad 5$

1 Introduction: shaping agricultural investments and markets for inclusion $\quad 10$

$\begin{array}{ll}\text { 1.1 Report aims and structure } & 10\end{array}$

1.2 Why shape agricultural investments and markets? 12

$\begin{array}{ll}1.3 \text { Analytical framework and boundaries of the study } & 16\end{array}$

2 Getting the basics right: the wider policy environment 19

$\begin{array}{ll}\text { 2.1 Agriculture within wider development policies } & 19\end{array}$

2.2 Investment in infrastructure and institutions 21

2.3 Cross-cutting gender laws and policies $\quad 24$

2.4 Voice and participation in policy design and implementation 26

2.5 Summary of key findings, Section $2 \quad 28$

3 Policies for inclusive agricultural investment 29

3.1 Which policy levers currently favour large-scale investments? 29

3.2 What has worked and what has failed around the world in supporting inclusive
investment?

3.3 Summary of key findings, Section $3 \quad 44$

4 Policies for inclusive market governance $\quad 46$

4.1 What are the policy levers to shape markets? 49

4.2 Summary of key findings, Section $4 \quad 64$

5 Conclusions: policy and advocacy priorities for inclusive agricultural $\begin{array}{ll}\text { investments and market development } & 67\end{array}$

$\begin{array}{ll}\text { Whose investment? } & 67\end{array}$

$\begin{array}{ll}\text { Policy matters } & 68\end{array}$

Adapting policy to different 'rural worlds' $\quad 69$

The gaps between intent, design, and implementation 71

$\begin{array}{ll}\text { Policy analysis and power } & 71\end{array}$

$\begin{array}{ll}\text { What role for producer organizations? } & 72\end{array}$

$\begin{array}{ll}\text { Closing comments } & 73\end{array}$

Bibliography 


\section{FOREWORD}

Agriculture is back on the agenda. With almost two billion people dependent on 500 million small farms in developing countries, and given the high and volatile food prices of the last five years, the world is waking up to the need for more investment in agriculture. In the context of deregulation and liberalization of agricultural markets, the current economic crisis, and the interest of companies and others in securing access to land, water and agricultural commodities, this has translated into an emphasis on private investment.

The potential double benefit of employing the poorest people while ensuring enough food for all is tantalising. Such investments can certainly reduce the shortfall in productive resources technology, skills, and infrastructure - that many developing countries suffer from, and generate economic benefit. However, to date they have often failed to generate positive impacts in terms of poverty reduction, wellbeing or resource efficiency. They have also often been blind to the fundamental role that women play in food production, and the drudgery they face in maintaining farms and caring for the family, unpaid and with few improvements in their lives.

Oxfam and IIED both work on inclusive business models that seek fair and transparent relationships between large corporations and small-scale producers in support of sustainable livelihoods, women's rights and poverty reduction. We have seen how missed policy opportunities and market failures impede progress, with the role of government and public policy relatively absent in the discourse on investment and agricultural market development in recent years. This research aims to tackle this governance gap.

The research has highlighted key policy levers and innovation in public policy that can better shape livelihoods programmes, helping Oxfam identify ways through programme policy and advocacy to deliver better results for an inclusive sustainable agricultural development. It also provides opportunities to strengthen the links between our programme learning and our GROW campaign, which is working to build a new global governance that averts food crises while increasing public and private investment that supports small-scale food production.

For IIED, the research has provided an opportunity to build on two different strands of work the work on agricultural investment, large-scale land acquisitions and inclusive investment models, on the one hand, and the work on the governance of agricultural markets to improve inclusion of small-scale farmers, on the other.

We hope that 'Tipping the Balance' will similarly help knock down the walls between programme and advocacy approaches to improving women's and men's livelihoods, and encourage readers to understand agricultural investment and market governance as one interlinked policy area.

The report provides some specific conclusions about relevant policy levers and how they can tip the balance towards or against women and men smallholders, drawing examples from country studies in Guatemala, Nigeria, Tanzania and the Philippines, as well as wider global references. Perhaps most importantly, the report provides a framework of analysis that we hope others will apply to the specific policies that are relevant to their own country or local context.

\section{Jeremy Hobbs}

Executive Director, Oxfam International

\section{Camilla Toulmin}

Director, IIED 


\section{EXECUTIVE SUMMARY}

More investment is required in agriculture if the sector is to meet a growing list of expectations, from rural poverty reduction to food security, stewardship of natural resources, and climate resilience. With high and volatile food commodity prices, governments have increased commitments to public investment in agriculture, but these have failed to materialize. A lot of attention has instead been paid to creating a facilitating environment for private investment in agriculture. Investment is now indeed flowing back into the sector, much of it from commercial investors rather than from governments.

Attracting investment is not an end in itself, but a means to an end. The quality of the investment - i.e. its ability to help a country pursue its stated policy goals - is critical. Stated goals underpinning investment promotion policies often encompass the improvement of women's and men's livelihoods, while respecting the environment - contributing to inclusive, sustainable development.

On a global scale, farming is dominated by small-scale producers who remain the main source of agricultural investment in many countries, with around 500 million small-scale farms supporting almost two billion people, nearly one-third of the global population. Women play a critical role. In Tanzania, for example, women are reported to produce about 70 per cent of all food crops. The big questions related to inclusive sustainable development for commercial investment in agriculture are therefore: (a) whether that commercial investment will support, bypass, or marginalize small-scale producers and women; and (b) what role public policy can play in tipping commercial investment and the benefits of agricultural markets in the direction of pro-smallholder and pro-women models of development, while respecting the environment.

That was the rationale for this collaboration between Oxfam GB and the International Institute for Environment and Development (IIED) - to analyze the policy levers on agricultural investments and the governance of agricultural markets that can tip commercial investment in the direction of agro-industrial or pro-smallholder and pro-women models.

This report develops a framework to examine the role of policy at three levels: at the level of agricultural policy basics (Section 2); at the level of directly shaping investments (Section 3); and at the level of market governance (Section 4). The key policy levers are summarized in Table 1, and elaborated on at the end of each section.

The work was supported by four country case studies, conducted in Guatemala, Nigeria, Tanzania, and the Philippines, and led by national researchers. 
Table 1: Summary of policy levers on agricultural investment and the governance of agricultural markets

\begin{tabular}{|l|l|}
\hline Level & Policy levers \\
\hline The basics & $\begin{array}{l}\text { Agriculture within wider development policies } \\
\text { Infrastructure and institutions } \\
\text { Cross-cutting gender laws and policies } \\
\text { Voice and participation }\end{array}$ \\
\hline Agricultural \\
investment & $\begin{array}{l}\text { Investment policies } \\
\text { Control over land and natural resources } \\
\text { Conditions for investor access to land and natural resources } \\
\text { Contract farming and supply chain relationships }\end{array}$ \\
\hline Market governance & $\begin{array}{l}\text { Support for producer organizations } \\
\text { Diversity of market outlets } \\
\text { Market co-ordination } \\
\text { Competition policy } \\
\text { Quotas and market preferences } \\
\text { Public policies for private standards } \\
\text { Trade policy }\end{array}$ \\
\hline
\end{tabular}

There are six inter-related sets of conclusions from the study.

\section{Policy matters - but currently it is biased against smallholders}

Changing that bias requires investment in small-scale agriculture - both in physical infrastructure and services that allow small-scale farmers and particularly women to invest in cash and food crops, and in the policy infrastructure that addresses their needs, and which provides voice and participation with the capacity to use them. A lack of appropriate policy and physical infrastructure tends to favour large-scale over small-scale farming by raising the cost of procuring produce from multiple scattered smallholdings, and increases the likelihood that investors will prefer in-house production on land that they own or lease themselves. Agricultural investment is then likely to follow a two-tier model, of commercial farms as outposts of global agribusiness operating in isolation from the majority of smallholdings on the economic and political margins. Public investment in physical and policy infrastructure can improve the 'investment-readiness' of smallholders and promote business models that support small-scale producers - with related benefits for poverty reduction, social cohesion, and natural resource management.

\section{The investment climates that support smallholder investment and corporate investments in agriculture, while having elements in common, are not the same}

In general, commercial investors are attracted by the returns that can be generated from largescale agriculture, which may or may not include smallholders as outgrowers. While policy can support more and fairer connections between commercial investors and small-scale producers - such as through oversight of contracts, incentives for producer organization, and oversight of trading relationships between producers and buyers - these value chain linkages are more likely to work best for a particular segment of rural societies (referred to in this report as 'Rural World 1' - see Box 1). This segment involves only the top 2-10 per cent of small-scale producers, primarily men, who have the assets and access to capital, organization, information, and infrastructure to 'step up' to formal and co-ordinated markets. Private investors working with a small segment of producers can create islands of excellence in a generally poor infrastructural environment, although government-supported infrastructure and services can enable smallholders in Rural World 2 to take the risks involved in 'stepping up' into these modern markets. 


\section{Policies must respond to the diversity of rural societies}

The challenge of promoting inclusive sustainable development in rural areas will remain unaddressed unless investment policies respond to the diverse needs and aspirations of the many different segments of rural societies.

This report points to the dangers of 'one size fits all' policies that ignore the diversity of smallholder households and livelihoods and effectively frame smallholders as scaled-down versions of large (and male) farmers. There is a strong economic rationale for investment in diverse farming systems that cater for the different 'rural worlds' that tend to overlap in any given locality, to bring better market opportunities, technology, and - of particular importance to the landless and to women - jobs, as well as reforms that increase people's access to and control over natural resources.

For example, for rural producers who are not formally organized in the market (Rural World 2), the most relevant policy levers are about improving the institutions and governance of domestic markets, including the 'traditional' and informal trade that forms the main links between smallholders and low-income consumers. Informal markets are particularly important for women, so policies to strengthen rather than undermine these markets are needed, as well as measures to address women's specific market access constraints. Much can be achieved with simple investments in physical infrastructure, such as local market spaces and investment in local processing, though warehousing and storage, market information, or transparent commodity exchanges can, when well designed, also reduce the impact of remoteness from markets and mitigate risk. This both ensures greater resilience for relatively vulnerable smallscale producers and allows greater scope for risk-taking, particularly by women and small-scale producers. Other important policy levers are available to governments to strengthen the organization and market power of small-scale producers (including channelling support for informal groups, given women's predominance in these organizations), encourage preferential public/food security procurement, provide a greater diversity of market outlets, make standards and certification work better for small farmers, break up cartels and monopolies, improve price stability and producer share of market value, and/or provide market preferences for small- and family-scale producers, for instance in export quotas or public procurement, or through protecting small-farm sectors from import competition.

On the other hand, for Rural World 3 groups, who have few land or other assets, wage labour is particularly important, and measures to promote fair labour relations and labour-generating sectors are an important part of promoting more inclusive models of agricultural investment. For example, there are issues of poor working conditions in plantations and packing houses that must be addressed through policy and business practice. 'Soft' infrastructure is important, particularly for women, such as education and health care, as well as social protection and informal savings schemes. Redistributive reforms are also needed to increase access to land and other natural resources. Integrated social protection mechanisms (such as the labour laws in India) can reduce vulnerability to shocks and help build infrastructure such as irrigation systems, which can in turn build climate resilience. 


\section{Box 1: Three rural worlds}

- Rural World 1: These are the 2-10 per cent of producers with access to capital, organization, information, and infrastructure, who can more easily 'step up' to formal and co-ordinated markets - i.e. the richest of the poor.

- Rural World 2: These are the majority of smallholders, who are 'hanging in' - and who are generally more reluctant than those in RW1 to invest in the agricultural part of their livelihoods. They are also less likely to be formally organized in the market, are likely to trade with the informal sector, and may derive part of their incomes from waged work. State institutions and modern agri-food business are usually inaccessible for smallholders in RW2.

- Rural World 3: Many small-scale farm households are approaching landlessness; surveys in sub-Saharan Africa have shown at least 25 per cent to be in this position, controlling less than 0.11 hectare per capita. Tenant farmers and wage labourers are often the most marginalized rural citizens. There are around 450 million agricultural workers globally, 200 million of whom cannot cover their basic needs. Small-scale farms in RW3 are more likely to be female-headed households, and more likely to depend on off-farm labour opportunities. Policies and business initiatives that support smallholder production may not cater for the needs of these groups.

\section{Policy innovations in inclusive investment do exist}

Overall, prevailing trends in policy favour large-scale land acquisitions over small farm development. This bias is rooted in different policies, including those that regulate investment promotion and control over land and natural resources. But the country case studies undertaken for this report and the wider literature also provide examples of policy innovations that support investment by small-scale farmers and create incentives for models of corporate investment that include them. Measures that strengthen local control over land and natural resources, including legal requirements for local consultation and free, prior, and informed consent, effective regulation of commercial investment, and targeted government action to promote the equitable inclusion of small-scale producers in value chains all tend to promote more inclusive forms of investment in agriculture. But no policies were identified with regard to investment regulation that adequately addresses the important gender dimensions of agricultural investments. There is great potential for policy innovations that address gender equality, such as helping overcome women's 'time poverty' or ensuring their control over key assets.

\section{Effective implementation is vital}

There is a major gap between good policy intentions and what is happening on the ground. Effective policy requires not only well thought out policy design, but also sustained investment in implementation. This includes capacity strengthening of government agencies and regulators and among the groups that would stand to gain from proper implementation, including smallscale producers themselves. Mechanisms for dispute resolution are also essential. This also includes budget allocations that reflect policy intent, relevant targets, and an implementation bias towards small farms. The capacity and influence of 'national machineries' responsible for promoting gender equality objectives need to be strengthened too. Equally, there is a need to address the conflicts that frequently arise between progressive statutory law, on the one hand, and customary norms that perpetuate gender inequality, such as patriarchal land allocation, on the other. 


\section{Politics matter}

Vested interests undermine socially optimal outcomes, yet without a political analysis there is a risk of assuming that politicians choose policy in a socially optimal way and of constructing a normative analysis that focuses on technical solutions to the challenges of economic liberalization. There is also a risk of tacitly endorsing the macro-economic and political roots of poverty and thereby reducing the policy aims of inclusive and sustainable development to defensive strategies to alleviate poverty and reduce environmental degradation.

Lobbying and advocacy must not stop at the point when new policies are introduced, but must continue to ensure dedicated interventions in support of smallholders and women and to prevent unintended consequences. The final question then arises as to the investments that are required for inclusive policy. That has much to do with transparency and accountability, to allow citizen oversight, and innovations that create space and capacity support for small farmer voice in influential policy institutions. But such policy also has to recognize that the world of smallholder agriculture and its associated trade is largely informal, and out of reach of most instruments and institutions of public policy.

Some commercial investments in agriculture are undesirable under any circumstances, for example if investments lead to large-scale clearances; or have no connection to or multipliers with the domestic economy; or privilege just a small group of the rural population; or make no contribution to domestic food security. But effective use of policy levers can make a difference in promoting models of commercial investment that encourage inclusive sustainable development. As we head into an uncertain era of extremes in commodity prices, climate change, and generation change, with disillusionment with farming livelihoods deterring young people from going into farming, getting this policy environment right for governing investments and markets is more important than ever. 


\section{INTRODUCTION: SHAPING AGRICULTURAL INVESTMENTS AND MARKETS FOR INCLUSION}

\subsection{REPORT AIMS AND STRUCTURE}

This report develops a framework to examine how public policy shapes commercial investments in agriculture, and the subsequent working of markets, in favour either of small- or large-scale farming, and in favour of or against women farmers. By identifying the policy levers that shape agricultural investments and markets, this report aims to support more targeted and strategic programme policy and advocacy that favour small-scale farm development and promote equal opportunities for women and men. It is divided into three sections:

- How policy supports, neglects, or discriminates against agriculture in general, and how it supports or discriminates against women in small-scale farming (Section 2);

- How policy shapes investments: Section 3 examines the role of policy in influencing corporate investments in agricultural land, in agricultural production, and in primary processing;

- How policy shapes the working of markets: Section 4 discusses the governance of markets in favour of or against smallholder production. 'Governance' refers to the elements that shape the terms on which actors participate in a market. Governance for inclusive market development balances risk and reward between market actors, especially between women and men in small-scale agriculture and the rest of the market, and thereby allows small-scale farming and women in smallholder agriculture to flourish.

The report is global in scope, but the conceptual framework underpinning it was tested through four country studies carried out in Guatemala, Nigeria, Tanzania, and the Philippines (see Box 2). The country studies aimed to ground the analysis in diverse contexts from Latin America, Africa, and Asia, without however purporting to develop a comparative analysis between the four countries. Also, it is recognized that developments in these four countries are not necessarily representative of wider trends, so the report also draws on evidence from other country contexts where appropriate.

The report ends with conclusions that frame the policy landscape and summarize the key issues identified. 


\section{Box 2: The country studies}

It is the intention to publish these country studies in 2013. They will be available from http://www.oxfam.org.uk/policyandpractice and http://shapingsustainablemarkets.iied.org

\section{Guatemala}

The agricultural sector in Guatemala has experienced significant changes in the past 20 years, with the growth of investment in plantation agriculture driven by a framework of laws that provide incentives, especially substitutes for petroleum fuels. Agricultural policy and investment support for small farmers in Guatemala is limited. There are government plans that refer to the promotion of rural development, but actions are few and there is little momentum or budget allocation, compared with the commercial and industrial sectors.

Report: 'Opciones de política para las inversiones agrícolas y la gobernanza de los mercados en apoyo de la agricultura a pequeña escala' by Guillermo Díaz, Instituto de Investigaciones Económicas y Sociales (IDIES), Guatemala.

\section{Nigeria}

Small-scale farming in Nigeria is characterized by unequal access to key resources and low levels of investment. The policies shaping investment include expansion of outputs through agricultural projects, subsidies on inputs, agricultural insurance, and policies on investment promotion, agricultural finance, land tenure, and tax, which are designed to shape investment in a positive direction. However, discrimination is widespread in three areas: land, finance, and input supply policies.

Report: 'Policy Options for Agricultural Investments and Governance of Markets in Support of SmallScale Agriculture in Nigeria' by Prof. Aderibigbe S. Olomola.

\section{Philippines}

Accelerating agricultural investment is one of the key strategies of the Philippines government to generate employment, increase productivity, improve incomes, and alleviate poverty in the countryside. While promoting investment, the government is also giving prime importance to sustainable development that addresses concerns about the environment, food security, and equity. However, the problems faced by small-scale producers are multi-dimensional, regardless of whether they are linked with large investors or not.

Report: 'Policy Options for Agricultural Investments and Governance of Markets in Support of SmallScale Agriculture in the Philippines' by Larry Digal, School of Management, University of the Philippines, Mindanao.

\section{Tanzania}

Smallholder farmers - the majority of whom are women - produce most of the food eaten in Tanzania. They have both positive and negative experiences in their various encounters with the government and corporate investors in farmland. There are many broad and sectoral policies, strategies, and initiatives that aim to develop agriculture in Tanzania. Most of these look very good on paper, but lack a clear focus and implementation strategies that would preferentially target smallholder farmers, especially women.

Report: 'Policy Options for Agricultural Investments and Governance of Markets in Support of SmallScale Agriculture: Tanzania Country Report' by Honest Prosper Ngowi. 


\subsection{WHY SHAPE AGRICULTURAL INVESTMENTS AND MARKETS?}

On a global scale, farming is dominated by small-scale producers, with women playing a critical role. In Tanzania, for example, women are reported to produce about 70 per cent of food crops, and they also bear substantial responsibilities for many aspects of export crop and livestock production. ${ }^{1}$ Women also do most of the work needed to care for and maintain farming families, ensuring a labour force for smallholder agricultural production, and they do so with minimal infrastructure and services, such as piped household water, electrification, or health and education services.

In many low- and middle-income countries, agriculture accounts for a major share of the economy, although its share of gross domestic product (GDP) is declining. With government investment falling, small-scale producers remain the main source of agricultural investment in these countries, with 500 million small-scale farms supporting almost two billion people, nearly one-third of the global population. Yet it is these very same small-scale producers who are the most food-insecure - due to lack of access to the markets, resources, finance, infrastructure, and technologies enjoyed by large farms. ${ }^{2}$ Given that growth in small-scale agriculture has twice the effect on the poorest people as growth in other sectors, ${ }^{3}$ appropriate investments in smallscale producers in developing countries are where major gains in agricultural productivity and poverty reduction can be achieved. Food security, poverty reduction, employment, social cohesion, natural resource management, and adaptation to climate change all depend to a greater or lesser extent on the inclusive development of the small farm sector.

Expectations of the world's half a billion small-scale farms are rising at a time of rapid economic transition driven by modernization, and at a time of high and volatile food commodity prices. These increased expectations come after decades of low public sector investment in agriculture and a cost/price squeeze on rural households. The Maputo Declaration adopted by African leaders in 2003 stipulates that at least 10 per cent of total government spending should be targeted at the agricultural sector with the goal of attaining food security. ${ }^{4}$ But according to statistics from the UN Food and Agriculture Organization (FAO), the share of total government expenditure going to agriculture has decreased in all regions except Europe and Central Asia; in countries in sub-Saharan Africa, the share was 3-6 per cent over the period 2003-07 (Lowder and Carisma, 2011). Over the past few decades, budget cuts have driven a reduction in government services in rural areas, including extension, health, and education services, a handing of market functions to private sector traders, and the closure of public storage infrastructure.

Corporate investment, by contrast, has increased in recent years, especially since the food price hikes of 2007-08, with a wave of large-scale investments in farmland and farming by agribusinesses, investment funds, and government bodies. According to some estimates, agricultural foreign direct investment (FDI) alone has risen from an average of $\$ 600 \mathrm{~m}$ annually in the 1990s to an average of $\$ 3 \mathrm{bn}$ in 2005-07, with much more private investment promised under the World Economic Forum's New Vision for Agriculture (WEF, 2012). This commercial investment takes very diverse forms - from companies acquiring very large areas of land for plantation agriculture in Africa, Asia, and Latin America through to operators setting up processing facilities that source produce from small-scale farmers. A complex set of factors is driving the renewed interest in agricultural investments, among them the widespread expectation that agricultural commodity prices will tend to rise in the medium to longer term as a result of global imbalances between supply and demand.

A recent wave of large-scale land acquisitions for plantation agriculture in the global South has raised real concerns that small-scale producers - farmers, pastoralists, and foragers - are being marginalized and displaced (see Boxes 3 and 4)..$^{5}$ An area eight times the size of the UK has been sold off or leased out globally in the past decade. ${ }^{6}$ Therefore there is a need for public action to support agricultural investment by small-scale producers, and to ensure that corporate investment is inclusive of those producers. 
Box 3: Evidence on the development outcomes of large-scale land acquisitions

Large-scale land acquisitions in the global South have kindled much international debate, in which strong positions are taken on the impacts of such acquisitions on rights, sovereignty, livelihoods, development, and conflict at local, national, and international levels. A large body of evidence shows that these deals have so far delivered few of the benefits that governments and communities hoped to obtain, and are causing harm to local livelihoods. In many recipient countries, small-scale producers have insecure rights to their land, and governments are allocating land without adequate consultation or compensation. ${ }^{7}$ Some of the world's poorest people are losing their land. There have been reports of forced evictions in Honduras, ${ }^{8}$ Guatemala, ${ }^{9}$ and Ethiopia. ${ }^{10}$ Loss of land can have catastrophic consequences for local livelihoods, social identity, and the local sense of justice. Impacts extend beyond smallholders to tenant farmers on smallholdings, who may have their livelihoods sold or leased off from underneath them by the owner.

The jobs created by plantations are often few, short-lived, and low-paid, particularly on highly mechanized farms, and people who lose land do not necessarily get the jobs (Deininger et al., 2011; Anseeuw et al., 2012). There is so far limited evidence of opportunities for local businesses, partly because several large investments have run into difficulties or have even been terminated. ${ }^{11}$ The lack of alternative livelihood options means that those who lose their land are vulnerable to destitution. In Guatemala, largescale sugar cane and oil palm developments have driven temporary and permanent migration to farms in the south or in the service sector in the capital city. Real concerns have been raised about some publicly available contracts underpinning large land deals, which have few strings attached. ${ }^{12}$

There are other resource implications. Some investment contracts grant investors priority access to water, which is an increasingly scarce resource. In times of water shortage, local farmers may be adversely affected. ${ }^{13}$ In Southeast Asia, the expansion of oil palm plantations is eroding local control over ancestral forests. ${ }^{14}$ Where a concern to minimize the risk of local conflict leads investors and governments to target lands that are currently not under cultivation, land deals are likely to impinge on lands used for grazing or foraging. This will have a disproportionate negative impact on pastoralists, who depend on continued access to grazing, but also on women, who in many African societies are responsible for collecting wood and forest products. ${ }^{15}$

\section{Box 4: Growing competition for land in Guatemala}

Much debate about large-scale land acquisition has focused on Africa. But the global land rush is happening elsewhere too. Take the case of Guatemala. According to official figures, at the end of 2011 there were 1,288 land disputes in the country. The Northern Transversal Strip region is especially conflict-ridden, with pressure coming from companies that grow oil palm and sugar cane, as well as from oil exploration, mining, and hydroelectric plants. In the Polochic Valley, conflicts arose with the arrival of oil palm plantations in 1998 and sugar cane in 2002. Many Polochic Valley farmers chose to sell or lease their holdings, leading to the eviction of families of young tenant farmers, who have been forced to migrate to other regions of the country. In Sayaxché Township, palm companies have aggressively acquired land and oil palm plantations are expanding rapidly. Studies show that in just a decade four companies have occupied more than 60,000 hectares of land in Sayaxché, representing 16 per cent of the municipality's area. In most cases, after two years families have seen none of the money from the sales and have failed to buy other land or set up a business. In a period of huge agribusiness investment, Guatemala has gone from a position of self-sufficiency in food to being a net importer. 
Polochic Valley communities have expressed concern about the water consumption of sugar cane and oil palm plantations and the impact of this on small-scale irrigation.

Sources: Testimonies from the community via Oxfam research visit to Sayaxche, September 2012;Guatemala country study.

However, although agriculture is largely a private enterprise, public policies play a critical role in shaping the operation and outcomes of agricultural investments and markets. Ultimately, the private sector cannot replace broader government responsibilities such as access to basic services and utilities, support services such as extension, or greater economic opportunities and infrastructure. Public policy sets the wider investment climate and can tip investments to favour either large-scale agri-industrial development, on the one hand, or inclusive development of existing small-scale producers on the other. And once investments are made, policies influence market governance, so that the distribution of power, value, and risk between value chain actors can constrain or support a fair share of the benefits of farming going to smallholders and to women.

Agriculture plays a major role in food security, as the crucial 'growth spark' in the take-off of developing economies, with benefits for many of the world's poorest people, ${ }^{16}$ and as a sector which impacts and is impacted by the environment. It is critical that policies are in place to ensure that the growing commercial investment in agriculture maximizes rather than undermines the pursuit of sustainable development goals such as poverty reduction, environmental sustainability, and climate resilience. It is also critical that the investment that small-scale producers inject into their farms and the farm labour force is properly recognized and supported with appropriate research and development, extension services, infrastructure, and other investment.

For decades, there has been debate about the pros and cons of small-scale and large-scale farming. ${ }^{17}$ Crops and contexts are different, and the comparative advantage of the two types of farming can change over time, such as with technological innovation. Small- and large-scale farming work together in many places. But there is strong evidence to show that, in poorer countries, small farm development can not only provide a commercially viable option but can also maximize pursuit of poverty reduction and environmental protection, mainly because of its more labour-intensive production methods (Wiggins et al., 2010). Conversely, the spread of large-scale, mechanized, intensive farming in sometimes fragile environments, and where there are few off-farm livelihood opportunities to absorb rural labour, can impoverish those who lose land to plantation agriculture.

Inclusion and exclusion in agricultural development are not just about the scale of farming, but also about gender equality. Women in smallholder households play a substantial role in producing food for global markets, as well as for domestic markets and home consumption, and the incomes of poor rural women tend to contribute more to household food security and family welfare and education than the incomes of men (World Bank et al., 2009). Estimates also suggest that by providing women with the same level of access to resources as men, they could increase yields on their farms by 20-30 per cent, in turn reducing the number of hungry people in the world by 12-17 per cent. ${ }^{18}$ More fundamentally, discrimination against women is a violation of fundamental human rights. Yet, due to the prevalence of patriarchal socio-cultural attitudes and practices in most developing countries, women - and poor rural women in particular - face inequalities in access to basic services (including education and health) and productive assets (including land, credit, agricultural extension, training, and inputs). Thus, for example, a survey conducted in Chichoy Alto village in Chimaltenango in Guatemala found that, of 52 families surveyed, fewer than 4 per cent of households had land registered in a woman's name. ${ }^{19}$ And in Nigeria, the access of male farmers to chemical inputs, extension services, storage facilities, and hired labour is more than twice as high as that of their female counterparts. ${ }^{20}$

Moreover, women tend to be under-represented in traditional governance structures, and face unequal power relationships within the household. Women also take on a greater share of 
domestic and care work than men, which limits the amount of time that they can spend on 'productive' and income-earning activities. ${ }^{21}$ In Ghana, for example, women on average spend more than three times as many hours per week on domestic work than men, averaging 39.5 hours while men do only 11.3 hours (Ghana Statistical Service, 2008). Rural communities receive little investment in labour- and time-saving infrastructure for household tasks, such as cleaning and washing, food processing and cooking, and fuel and water collection - making these tasks arduous and time-consuming.

These basic inequalities have knock-on effects on women's ability to benefit from agricultural markets and investments. Thus, in relation to market access, women's poorer access to land and other productive resources translates into smaller production volumes, which prevent them selling into more lucrative markets. Moreover, women's domestic responsibilities limit the amount of time they can spend on marketing activities, and their lower education levels contribute to poorer access to market information (Baden and Pionetti, 2011).

Equally, in relation to agricultural investments, experience to date shows that women bear a disproportionate share of the negative impacts of large land deals for plantation agriculture. In particular, available evidence indicates that women farmers tend to be excluded from or marginalized in any local consultation processes that may be carried out, due in part to their typical exclusion from local governance structures. Also, where the investment involves resettlement and payment of compensation, the main beneficiaries of these schemes tend to be men rather than women farmers, because men mostly control the land. Even when local farmers sell their land voluntarily, women tend to have little control, due to their inferior status within the household. For example, in Guatemala's Petén department, there are communities in Sayaxché which have disappeared because 100 per cent of the families have sold their plots, and other communities which are now surrounded by oil palm plantations. Of the 60,000 hectares of oil palm that is cultivated, most is on land that belonged to small farmers. ${ }^{22}$ It is very often the male head of household who sells the plot, without consulting other family members or tenants working the land (Dürr et al., 2010; Observatorio Ambiental, 2011). Where land appropriated by investors was previously communal land, women tend to suffer disproportionately from loss of access, due to their greater reliance on communal lands for their livelihoods. ${ }^{23}$

Women also tend to lose out in investment models that involve collaboration with local farmers, rather than large plantations, due to their lack of formal recognition. For example, contract farmers for many crops are predominantly male, due in large part to men's predominance in land ownership. And in contract farming situations, wives of male contract farmers typically contribute a substantial amount of labour on the contract farms but this is unrecognized by the contracts, leaving women with little of the income and few of the benefits (see Section 3).

Thus, gender inequalities are widespread in women's experience of both agricultural investments and market access. For the large part, the root causes of these inequalities lie in socio-cultural norms, perpetuated in government policies. In fact, as the following sections demonstrate, many government policies relevant to agricultural investments and markets discriminate against women because they are 'gender-blind'. Unfortunately, experience shows that gender-blind policies, including those that are supportive of smallholder agriculture in general, are likely to perpetuate existing inequalities unless proactive efforts are made to address gender imbalances (World Bank et al., 2009). In other words, the fact that a policy is 'pro-smallholder' is inadequate in itself to ensure that women farmers will benefit.

Therefore, in order to ensure that women benefit rather than lose out from investments and market opportunities, relevant policies must incorporate explicit objectives and targets that address women's resources, agricultural and business development services, and infrastructure (i.e. gender-sensitive policy intent) and must be supported by implementation systems that include affirmative measures for women. It is for this reason that a considerable proportion of this report is dedicated to identifying policy elements that can specifically contribute to genderequitable results. 


\subsection{ANALYTICAL FRAMEWORK AND BOUNDARIES OF THE STUDY}

The framework and boundaries of the study are summarized in Figure 1, with the two policy areas that may tip commercial investment in agricultural production and market governance in favour of agro-industrial or smallholder models.

There are two inter-related areas of policy analysis central to the framework. The first focuses on the role of policy in influencing corporate investments in agricultural land, in agricultural production, and (when directly associated with investments in agricultural production) in primary processing. The focus is on the policy levers that influence investments in favour of either smallholder or agro-industrial production models, and in favour of either women or men. The second area of analysis focuses on the governance of markets in favour of or against smallholder production.

There are, of course, interactions between these policy areas. In practice, the working of markets significantly affects investment decisions, and vice versa. And while policy matters, as it shapes opportunities for investors, business considerations are key factors in shaping investment. For example, concerns about the reliability of supplies (volumes, quality, and timeliness) are a key driver of investment in land for agricultural production, often by traders and processors pursuing vertical integration strategies. And, as noted above, in the case of gender relations, socio-cultural attitudes and practices influence government policy, which in turn determines the extent to which women benefit from investments. The right government policies can be a 'driver of change' in socio-cultural norms relating to smallholder women's roles and rights, although other institutions are clearly important as well.

Figure 1: Analytical framework and boundaries of the study

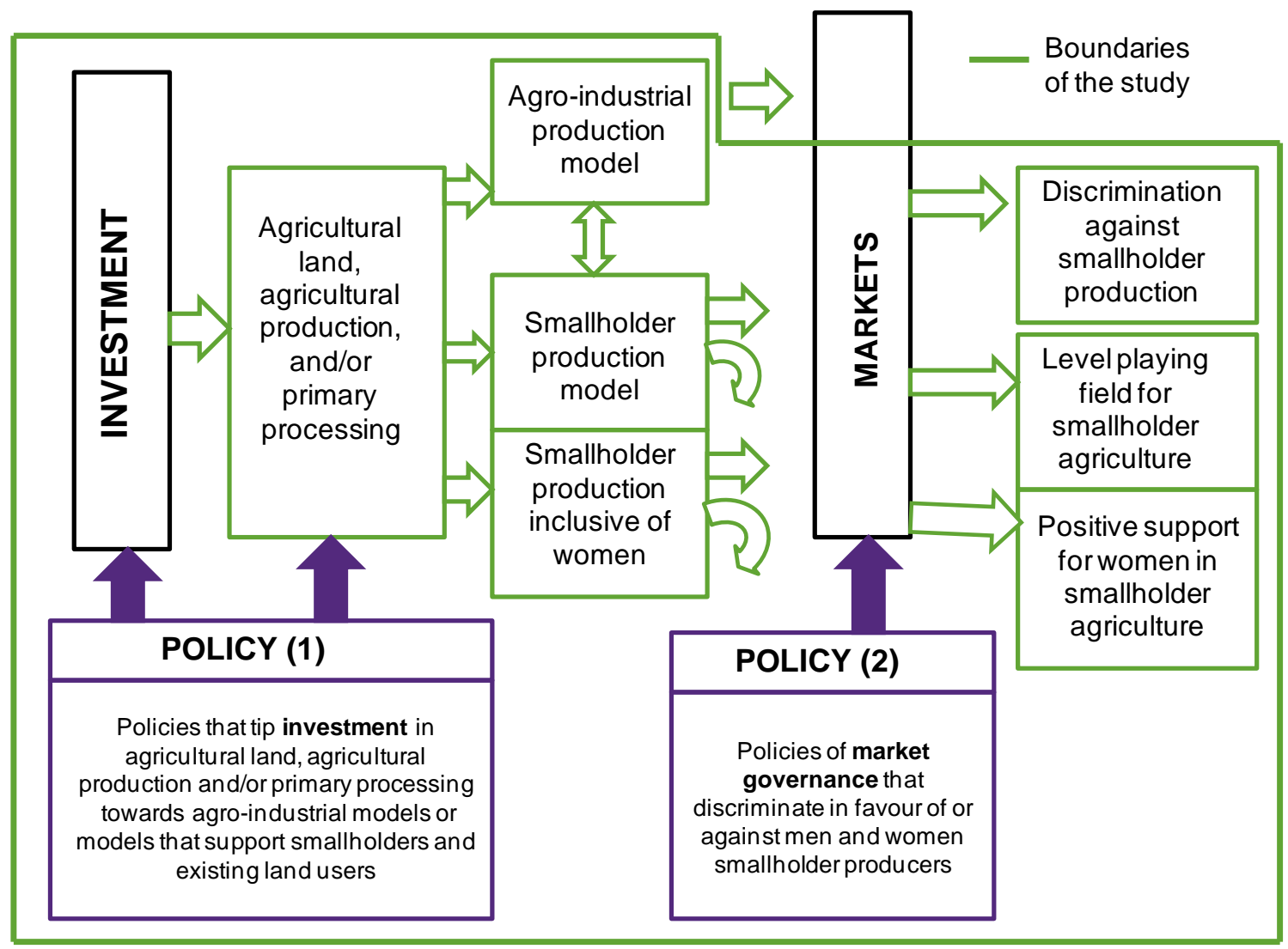


For the sake of simplicity, Figure 1 suggests stark contrasts between the different development options of agro-industrial and smallholder production models. In reality, there is much diversity within each option, and the borderlines between the two are typically fluid. Investment models that involve smallholders as outgrowers around nucleus estates illustrate that there may be a continuum between the two sides.

Also, small-scale producers are themselves highly differentiated. Policies that are prosmallholder need to take that differentiation into account. For example, policies that support smallholder production may not respond to the needs of informal tenant farming and wage labour, including for the many less well-off smallholder families who use these as a means to complement their farming incomes. In this regard, policies that support a mix of agro-industrial and smallholder models may provide more inclusive development opportunities (see Box 5).

\section{Box 5: Differentiation among small-scale producers}

Segmentation of smallholder agriculture has been described in a number of ways, based on land holding (Hazell et al., 2010), access to assets and productive environment (Berdegué and Escobar, (2002), orientation to local, domestic, or international markets (Torero (2011), livelihood strategy (Dorward et al., (2009), and entrepreneurial attitudes. ${ }^{24}$ There are other forms of marginalization and disadvantage for poor people in rural areas, including remoteness, gender, ethnicity, and caste. A simple classification into three 'rural worlds' (Vorley, 2002) provides a useful shorthand of rural differentiation:

- Rural World 1: These are the 2-10 per cent of producers with access to capital, organization, information, and infrastructure, who can more easily 'step up' to formal and co-ordinated markets - i.e. the richest of the poor. Policy priorities for RW1 are mainly about supporting vertical trading relationships in value chains, such as enforcement of contracts.

- Rural World 2: These are the majority of smallholders, who are 'hanging in' - and who are generally more reluctant than those in RW1 to invest in the agricultural part of their livelihoods. They are also less likely to be formally organized in the market, are likely to trade with the informal sector, and may derive part of their incomes from waged work. State institutions and modern agri-food businesses are usually inaccessible for them. Policy priorities for RW2 are mainly about horizontal improvement in the performance and inclusiveness of a whole sector, upgrading the informal sector, and preserving a diversity of markets and a process of inclusive formalization, as well as measures that strengthen local rights to land and natural resources.

- Rural World 3: Many small-scale farm households are approaching landlessness; at least 25 per cent of households in surveys conducted in sub-Saharan Africa were shown to be in this position, controlling less than 0.11 hectare per capita (Jayne et al., 2002; Jayne et al., 2011). Tenant farmers and wage labourers are often the most marginalized rural citizens. There are around 450 million agricultural workers globally, 200 million of whom cannot cover their basic needs. ${ }^{25}$ Small-scale farms in RW3 are more likely to be female-headed households, and are more likely to depend on off-farm labour opportunities. Policies and business initiatives that support smallholder production may not cater for the needs of these groups. Policy priorities for RW3 are more oriented to labour markets, especially as they relate to women, and to redistributive reforms to increase access to and control over natural resources.

There are also risks of stereotyping households as one 'rural world', based on market orientation. A single household may be involved in three types of market - labour markets, informal markets, and formal/export markets. A diversity of markets is key for small-scale producers. Women may be effectively landless within a household that owns land, and women have different status and opportunities within a certain type of household. 
The focus of the framework is on national policy. International policy is discussed insofar as it affects national policy - but international policy can have more direct implications for investment processes. Donors, for example, provide investment advice and technical support to developing country governments and also, in the case of donors such as the World Bank, direct support to land reform programmes. Policies in investors' home countries also matter a great deal; they may provide financial and other incentives and support for companies operating overseas. Mandates for renewable energy are another lever. In Europe, for example, the $2009 \mathrm{EU}$ Renewable Energy Directive (RED) set a target of increasing the share of energy from renewable sources to at least 20 per cent of gross final consumption and at least 10 per cent of the final consumption of energy in transport, all by 2020 . This measure effectively creates a guaranteed market for biofuels, and has proved to be an important driver for much biofuelrelated land acquisition in Africa.

The framework is not restricted to global value chains, acknowledging that domestic and regional markets are more important for smallholders. Nevertheless, it is understood that smallholders associated with large-scale investment in agricultural production and primary processors will often be producing for the export market. The focus is primarily on farming, although some reference is made to other activities, such as pastoralism and foraging.

Investment in primary processing is within the scope of the research when directly associated with agricultural production. Investments in agricultural production include models involving large-scale land acquisitions, namely where a company acquires ownership or long-term use rights over land to establish a plantation, and models where the investment focuses on processing and the company sources produce from neighbouring farmers through contract farming and supply chain relations. Mixed models are also considered, e.g. where a venture combines a nucleus estate and an outgrower scheme. Analysis of processing that is not directly linked to agricultural production is out of the scope of this report, as is investment in retail. The issue of environmental sustainability and the policies needed to encourage investment that ensures that no environmental harm is done and which protects the natural resource base would require a full paper in itself and is also out of scope. Broader policies such as government services to support unpaid care work and household work are likewise beyond the scope of this study.

Finally, it is worth clarifying what this report is not about. Policies are, importantly, about politics and power relations. A good understanding of the political economy and power relations that underpin policy formulation and implementation is critical for effecting policy advocacy. This report maps key policy levers, but does not discuss in depth the politics that underpin them. It addresses the importance of producer voice and participation in policy design, but it does not have space to analyze how small-scale producers, as opposed to large investors, have been engaging with policy processes to bring about change. Policy is defined in relatively narrow terms around public policies, without addressing the policies, standards, and protocols developed by the private sector and their influence over government policy, or the informal governance arrangements that powerfully influence the lives of small-scale producers in many parts of the world. Also, the emphasis is on policy design, though it is recognized that many issues arise not from bad policy, but from lack of implementation of good policy - this is returned to in the Conclusions section. While the report examines policies individually, it is often the combined implementation of multiple policies, including their coherence or inconsistency, and the extent to which one policy takes priority over another, whether explicitly or in practice, that define the outcomes of policy making. 


\section{GETTING THE BASICS RIGHT: THE WIDER POLICY ENVIRONMENT}

Before considering policy that is specific to investment and market governance, this paper looks first at the overall policy environment in which investment is made. It reviews the bias of policy in favour of or against agriculture as a whole and the policies governing the provision of infrastructure and agricultural services, especially agricultural extension services and finance/credit. It also reviews how policy can discriminate in favour of or against the interests of women. Lastly, it addresses policy design and programming, and the voice of small-scale farmers and women therein.

\subsection{AGRICULTURE WITHIN WIDER DEVELOPMENT POLICIES}

A first set of issues concerns the place of agriculture in wider development policies, and the overall vision of agricultural development. Following decades of policy neglect of the sector, many governments in lower- and middle-income countries have attached renewed importance to agriculture within their wider development strategies. In Africa, for example, the 2003 Maputo Declaration committed governments to allocate at least 10 per cent of total government spending to the agricultural sector.

National policy also sets the tone in favour of agriculture. In Guatemala, the prioritization of rural development is evidenced by the policy guidelines recently developed by the Ministry of Planning and Programming of the Presidency (Segeplan). ${ }^{26}$ The guidelines identify rural development as a policy priority and provide for the promotion of development banks, farmers' organizations, improved access to land, and infrastructure development. Policy documents articulate the government's long-term vision of agricultural development and emphasize a competitiveness agenda that includes objectives to modernize and transform peasant agriculture into commercial farming through emphasis on productivity and tradability. In 2011, the Ministry of Agriculture, Livestock and Food (MAGA) published the 'Agricultural Policy 20112015 ' developed with the support of social and private sector organizations. With two axes, on food and nutrition security and on production and business development, this policy aims to promote the integration of rural communities into the market economy through promoting linkages; strategic alliances and trade; economies of scale; information on accessing the market; microcredit lines with an emphasis on women; new partnerships between producers and funders; and a strengthened system of basic grain storage. Although the previous government approved the policy, which has support from peasant organizations, the 40-84 initiative 'Integrated Rural Development Law' has met strong opposition from the private sector. The current government has proposed a plan that seeks to adapt the rural development policy to what they think is viable given the current policy and legal framework. ${ }^{27}$

Of course, there is a risk that official policy pronouncements do not necessarily translate into prioritization of agriculture in budgeting exercises. The weakening of public investment in agriculture is illustrated by Guatemala's budget allocations: the budget of MAGA was reduced by about a half between 2006 and 2011 - though in 2012, civil society analysis and pressure have led to a proposed realignment of budget lines towards promotion of the rural economy and an emphasis on women producers. Strategic choices about the roles of small- and large-scale farming are at the heart of agricultural development policies. Many of these policies support both small- and large-scale farming, although implementation may then prioritize one aspect over the other. For example, Mali adopted an Agricultural Orientation Act in 2006, and a similar piece of legislation was passed in Senegal two years earlier. These two laws recognize the 
roles of both large and small-scale producers in agricultural 'modernization'. In Mali, however, the rapid growth of large-scale land deals in the country's Office du Niger area ${ }^{28}$ suggests that the government has favoured large- over small-scale farming.

The Brazilian government acknowledged the specific needs of its four million small- and familyscale farms with the founding of the Ministry for Agricultural Development in 1999, so that 'family farms had their interests represented at the top political level for the first time'. ${ }^{29}$ The interests of agribusinesses continue to be represented by the Ministry of Agriculture. There are, of course, risks associated with relegating small-scale agriculture to a social sector and sidelining its economic potential.

Similarly, Tanzania's Kilimo Kwanza ('Agriculture First') initiative embodies a vision of agricultural modernization based on both small- and large-scale farming. However, in practice, many feel that the real policy thrust lies behind large-scale agriculture. Pillar 5 of the initiative involves amending the progressive Village Land Act of 1999 to facilitate access to village land for Kilimo Kwanza investments. The proposed amendment would make it easier for village land to be taken and transferred to large-scale investors. Activities under this pillar also include allocating land to a Land Bank, again with the aim of facilitating land access for commercial operators.

Following a major shift in economic thinking that has occurred since the early 1990s, governments in lower- and middle-income countries have looked to the private sector as a source of capital, expertise, and market links. The shift in thinking reflects the end of the Cold War and the failure of some state-centred development models. It also reflects the efforts made by multilateral lenders, development agencies, and knowledge institutions ${ }^{30}$ to support policy reform in poorer countries to increase their market-friendliness. Some have argued, for instance, that the World Bank's 'Doing Business' indicators have increased pressure on countries to improve their business climates, and external advice provided by multilateral lenders has resulted in investment-friendly reforms in several poorer countries. ${ }^{31}$

Given this policy shift, public-private partnerships (PPPs) have become an increasingly common approach to promoting agricultural development, including in relation to the promotion of commercial operations along strategic infrastructure corridors. In principle, these initiatives may be used to support both small- and large-scale farming. But concerns have been raised that some recent high-profile PPPs in agriculture may leave small-scale producers behind (see Box 6).

\section{Box 6: The Southern Agricultural Growth Corridor of Tanzania}

The Southern Agricultural Growth Corridor of Tanzania (SAGCOT) is a public-private partnership launched by Tanzania in 2010 to implement the Kilimo Kwanza initiative. It aims to catalyze private investment and improve agricultural productivity along a corridor of road, rail, and power infrastructure linking the port of Dar es Salaam with Zambia. The focus is on the development of large-scale farming and the involvement of small-scale producers in the supply chain, particularly through the 'hub and outgrower' model. While this initiative may bring new livelihood opportunities, some observers have expressed concerns. The vision is one of large capital investments for mechanized production, where small-scale producers can play a role insofar as they are integrated as outgrowers or suppliers to commercial hubs. Making land available to commercial operators appears to be an important concern. The SAGCOT Investment Blueprint lists land at the top of the priority policy actions necessary to facilitate the plan's implementation, particularly with regard to identifying land that could be used for agricultural production, streamlining arrangements for granting secure land rights to investors, and reforming the process that enables local communities to use their land as equity in joint ventures with investors. ${ }^{32}$

Sources: interviews carried out for this report; SAGCOT Investment Blueprint 
These strategic choices embedded either explicitly or implicitly within national agricultural development policies also have implications for gender equality, so it is important that gender considerations are taken into account in their development or revision. Many countries have started to recognize this and, often with the support of international donors, have reviewed their development and/or agricultural policies from the perspective of gender equality. Thus, in order to help ensure that women as well as men will benefit from the promised improvements in agricultural infrastructure and services, many national agricultural policies, including those of Guatemala and the Philippines, have incorporated specific objectives and measures to increase women farmers' access to agricultural extension, credit, and inputs. Section 2.2 below provides some promising examples of such measures.

While this represents an important step in the right direction, two key challenges remain. Firstly, implementation of these gender-focused policy elements has mostly been poor, a function of the fact that in most cases these objectives are not accompanied by explicit targets or budgets, or by the establishment and adequate resourcing of appropriate 'machinery' (World Bank et al., 2009).

Secondly, certain crops are often considered to be 'men's' or 'women's' crops, and certain positions in value chains are dominated by women or by men. The choice of crops and the stage(s) of the value chain in which governments choose to focus investment therefore have important gender implications and deserve more attention in policy making. Experience to date with the expansion of agricultural export sectors in developing countries has shown that the extent to which women benefit from expansion depends substantially on the crop(s) in question. Thus, for example, whereas women have tended to play a higher-profile role and to benefit more from investment in vegetable crops, they have benefited less from investments in certain tree crops, such as mango and cocoa (Chan, 2011; Chan, 2010). Women also play a more prominent role in certain parts of the value chain than others, predominating in the post-harvest stages (particularly processing and packing) in most export value chains (Lastarria-Cornhiel, 2006).

The implication is that, in order to increase the chances of agricultural export/agribusiness expansion strategies delivering real benefits to a significant number of women, these strategies should include a focus on crops that are traditionally grown by women, and should target investment in those value chain levels or functions where women predominate. For example, in a mango export promotion strategy prepared by the International Trade Centre, recommendations to support women in the Malian mango value chain highlighted the importance of supporting the expansion of the processing sector, given women's dominant role in drying and processing mango (International Trade Centre, 2011).

\subsection{INVESTMENT IN INFRASTRUCTURE AND INSTITUTIONS}

The state of rural and market infrastructure, services, and institutions can have major implications for the working of investments and markets in favour either of small- or large-scale producers, or of men and women. For example, companies may be inclined to procure from small-scale farmers rather than acquire land for plantation agriculture if the security, efficiency, and quality of supplies can be assured over the medium to long term. This depends on the existence of reliable storage and transportation networks, including rural feeder roads; on market facilities; on access to finance, inputs, technology and R\&D, and information and advisory services for small-scale farmers; on the level of producer organization, as farmer cooperatives can help improve traders' access to aggregated volumes of product of a reliable quality and safety; on open and competitive markets for efficient trade between regions and across borders; and, more generally, on functioning legal frameworks, reliable institutions, and an accessible and independent judiciary. Some of these priorities are returned to in Section 4.

Investment in infrastructure has a strong impact on rural incomes and especially on smallholders, and is important both for the agriculture and non-agriculture parts of rural 
livelihoods (Orden et al., 2004). Poor rural infrastructure or an urban bias in infrastructural development (noted in the Nigeria country study) adds costs to agricultural traders, contributes to delays and damage to crops during transport and handling, and limits competition among buyers, which is reflected in lower farm-gate prices.

Without these features of 'investment-readiness', investors may face strong economic incentives to secure supplies through exclusionary investment models. A lack of appropriate policy and physical infrastructure would tend to favour large- over small-scale farming by raising the cost of procuring produce from multiple scattered smallholdings, and would increase the likelihood that investors will prefer in-house production on land they own or lease themselves. Agricultural investment is then likely to follow a two-tier model, of commercial farms as outposts of global agribusiness operating in isolation from the majority of smallholdings on the economic and political margins. Public investment in physical and policy infrastructure can improve the investment-readiness of smallholders and promote business models that support small-scale producers - with related benefits for poverty reduction, social cohesion, and natural resource management.

While both the private and public sectors are often involved in infrastructure development, extension services, and the provision of credit, there are big differences between countries with regards to what is seen as a public and what is a private good. There is an overarching policy issue as to the appropriate role for government. Private investors in export horticulture have been inclined to work around the state, providing the bulk of the institutional framework - inputs, credit, extension services, scheduling of production, and transportation - and thereby creating islands of excellence in a generally poor infrastructural environment. But the more common approach is via PPPs. Several countries have adopted policies and enacted legislation to regulate PPPs as a way to promote private investment in public utilities and infrastructure. ${ }^{33}$

Investments in extension were hit particularly hard during structural adjustment, to the extent that many public extension services are moribund. In Guatemala, the late 1990s saw the dismantling of agricultural extension services, leaving small-scale producers without adequate support for productive activities. But in 2008, the government created the Outreach Programme, aiming to provide technical assistance and capacity building to small and medium farmers. In 2012 the Ministry of Agriculture, Livestock and Food (MAGA) reinstated the agricultural extension services system and began implementing the Zero Hunger Plan in 166 priority municipalities. Access to market information and skills support in negotiations and accounting can also help to reduce information asymmetries in trading.

There is also an important role for public policy in improving access to finance to address the well-recognized problem of access to formal credit when small-scale producers have traditional customary land ownership and no formal land tenure. Smallholders need finance to invest in more and better-quality inputs and to build, often with others, small-scale infrastructure (storage, transport, irrigation). This is often best achieved through co-operatives or specialized intermediaries, which can reduce the risk both to lenders and borrowers. However, often smallholders cannot meet requests for business plans and tax documents, and many of the company reports show how finance products can be very exclusionary in their collateral requirements. Policies that catalyze smallholder finance encourage financial institutions to lend to organizations representing smallholders, and encourage producer organizations (POs) to become bankable and provide effective demand for credit. This could include disaggregating rural interest rates so that risks and returns are more closely specified for different crops, providing some risk share or subsidizing premiums, and training bank officers to better understand the agricultural economy. ${ }^{34}$

Examples from the country studies of credit programmes intended to increase the supply of credit to small-scale farmers include:

- Dacrédito in Guatemala, which was created in 2005 to increase the supply of credit to smallscale farmers through a guarantee fund and agricultural insurance. The Guarantee Fund covers up to 80 per cent of the value of credit extended by private banks; the Rural 
Development Bank (Banrural) promotes economic and social development in rural areas of Guatemala by encouraging and facilitating savings, credit assistance and the provision of other financial services. Banrural is one of the few national bodies of formal banking to provide access to credit for the promotion of rural development

- The amended Agri-Agra Law (RA 10000) in the Philippines, which is designed to increase the volume of credit for the agricultural sector, thereby benefiting directly or indirectly smallscale farmers, including women. The old law (PD 717 approved in 1975) mandated all banks to allocate 25 per cent of their total loan portfolio to agriculture. This is still the same share in the amended law but at least 10 per cent of the 25 per cent is earmarked for agrarian reform beneficiaries, and the balance of 15 per cent will go to the entire agricultural sector. Women are also expected to benefit, as many are actively participating in agrarian reform communities, though the collateral value of land-reform land is limited due to restrictions on the right of sale. Despite the intent of these provisions, however, Oxfam in the Philippines is unconvinced that this finance will directly reach small farmers, particularly agrarian reform beneficiaries, given the experience with the old Agri-Agra Law.

Women as well as men small-scale farmers are, of course, likely to be benefit to some extent from the general investments in rural infrastructure and institutions outlined above. However, experience indicates that women smallholders are likely to benefit less than men unless specific measures are taken to ensure that the design and implementation of investments are relevant to their priorities and interests, and that specific policies or policy elements exist to encourage and support such gender-sensitive practices (World Bank et al., 2009). Thus in Guatemala, for example, under the ProRural programme the government has provided financial and technical assistance to small-scale producers to encourage them to convert their farms to oil palm production. However, the lack of explicit and effective gender equality measures meant that, as of 2009 , fewer than a quarter of the beneficiaries were women farmers. ${ }^{35}$

Similar experiences can be seen in credit provision, where the lack of an affirmative policy for women means that financial institutions usually perpetuate gender inequality. In all four of the case study countries, there are no legal restrictions on women accessing formal (or informal) credit. However, the existence of discriminatory practices means that, in practice, women in all four countries (albeit to a varying degree) have poorer access to credit than men (SIGI, 2012a, b, c, and d). In the Philippines, for example, despite the government's broader commitment to women's rights, men continue to have better access to larger loans than women, since on average land and property are registered in men's names and thus they are better able to meet collateral requirements. Similarly, although women have the legal right to independently enter into contracts and loans, many financial institutions still demand that the male partner co-sign any financial contracts, including loan agreements (SIGI, 2012c).

Nonetheless, certain types of policy or policy element that have been adopted by national governments have the potential to increase women's access to credit, including earmarking a proportion of credit sources for them. Thus, for example, the Act Providing Assistance to Women (RA7882) adopted by the Philippines government in 1995 legislated for 5 per cent of credit funds provided by government financial institutions to be set aside for a special credit window for women (Asian Development Bank et al., 2008) and Guatemala's Agricultural Policy 2011-1015 includes an objective to develop micro-credit lines and a credit guarantee fund aimed specifically at women.

Furthermore, while no concrete examples of such policy elements were identified in the research, national governments might fruitfully consider the adoption of policies that encourage financial institutions to introduce the types of loan mechanism and procedure that have been found to improve women's access to credit. These include flexible collateral/guarantee mechanisms, and the promotion of non-bureaucratic and gender-sensitive application procedures (including discouragement of the practice whereby the signature of a male head of household is required for a woman to obtain a loan (World Bank et al., 2009). 
A similar story can be found in the provision of agricultural extension services. While policies do not state a priority for men, in practice far fewer women benefit because of biases such as male personnel, focus on 'men's crops', or training given at times and places that exclude women. For example, the Joint United Nations Programme on HIV/AIDS (UNAIDS) estimates that women receive only 5 per cent of extension services worldwide (UNAIDS, n.d.). A key contributing factor is that most extension officers are male: according to FAO estimates, only 15 per cent of the world's agricultural extension agents are women (FAO, 2007a). Male extension officers are in turn more likely to contact male rather than female farmers, and in some societies women also face cultural barriers to interacting with male strangers, thus further restricting their access to extension services (Chan, 2010).

It follows that one important policy element that can help increase women farmers' access to extension services is a commitment to recruit more female agricultural extension staff. In recognition of this, the Nigerian government's Women in Agriculture Programme is trying to ensure that the extension service in each of the country's states has female extension workers at every level of operation, from state headquarters down to the field level. ${ }^{36}$ Also important is the commitment to adopt women-friendly extension and training methods. El Salvador provides one example of a government that has recognized the importance of this policy aspect, and the wider benefits that can result. The country's Unit for the Strengthening of and Support to Gender Policies at the Ministry for Agriculture and Livestock has helped the national extension programme to tailor training to women farmers, an investment that has led to enhanced agricultural productivity (World Bank et al., 2009). Although there have been significant advances in women farmer's access to extension services in El Salvador, there is still a significant gap in the percentage of rural women who access state training services and technology transfer programmes compared with men - averaging around 33 per cent compared with 67 per cent according to Technical Secretary of the Presidency statistics. Access to land, credit, and extension services of quality are one of the main demands of rural women, who believe that agricultural extension services continue to favour men, promoting their incorporation into more profitable rural businesses and encouraging women-only subsistence activities that reaffirm their traditional roles. ${ }^{37}$

In terms of investment in physical infrastructure and services, an important contribution that government policy can make towards gender equality in market access and benefits from investment is to improve the specific types of infrastructure and services that can help free up women's time. As Oxfam's programme experience has clearly demonstrated, a critical factor in removing barriers to women's agricultural productivity and economic empowerment is reducing the time that women spend on domestic and care duties. ${ }^{38}$ For example, Oxfam GB's programme from 2003-2006 worked with the state government of Rajasthan to provide water tanks and village stand-pipes to reduce the drudgery of water collection from distant water sources, saving women two hours per trip for use in other activities. Equally, improving health care and childcare services reduces the disproportionate impact of the care burden on women.

\subsection{CROSS-CUTTING GENDER LAWS AND POLICIES}

To achieve sustainable and substantive progress towards greater gender equality in the agricultural sector, and hence enhance benefits for women arising from agricultural investments and market opportunities, it is also necessary to challenge the underlying socio-cultural attitudes and practices that undervalue women's roles and contributions in wider society. Thus, even the best laws and policies supporting women in agriculture can achieve only limited impact if the broader policy environment continues to denigrate women's roles and status in other spheres of life.

Key to this broader policy environment are family law, inheritance (succession) law, and gender equality laws and policies. These cross-cutting polices are particularly relevant. Alongside 
customary law and socio-cultural attitudes and practices, they influence women's access to land and other productive resources as well as time. They also influence women's status within the household and hence their ability to claim and retain a fair share of income gained from participation in agricultural markets and investment projects, and the extent to which women are represented in customary, statutory, and corporate governance structures. This in turn influences women's ability to claim land rights and compensation, and to have a voice within governance structures of 'inclusive' business models.

Specifically, family law has an important influence on intra-household distribution of power and resources. In some countries, including, for instance, the Dominican Republic, Honduras, and Nicaragua, family law only recognizes men as heads of household, and it may also limit women's capacity to administer family property (for example, the Honduras Family Code grants husbands exclusive administration rights over family property) (FAO, 2007b). Both of these characteristics are likely to curtail women's ability to benefit from agricultural investments and market opportunities, e.g. impeding their access to credit and their ability to participate in contract farming schemes in their own right.

Most countries have now repealed such discriminatory clauses in their family laws (e.g. Brazil and South Africa), and many countries have gone a step further and have introduced explicit gender equality principles to counter gender-inequitable customary practices. Thus, in Ethiopia, for example, the revised Family Code of 2000 explicitly grants spouses equal rights in the management of the family, provides (with some exceptions) for community of property in relation to property acquired after marriage, and envisages joint administration of family property (FAO, 2007b).

Inheritance laws and laws governing the sale of property clearly have a critical influence on women's access to land, since women in developing countries acquire land mainly through inheritance, marriage, or land purchase (World Bank et al., 2009). In some countries the law still places restrictions on women's ability to inherit and/or buy and sell land, e.g. Tunisia (FAO, 2007b). Fortunately, most countries have now repealed such discriminatory clauses, and many have also incorporated explicit guarantees that women and men have equal rights to inherit land (e.g. Mozambique and Eritrea), that women as well as men have the right to buy and sell land, and that both spouses must provide consent for a transfer of marital property (e.g. Ethiopia) (FAO, 2007b; World Bank et al., 2009).

Many countries have now also adopted specific gender equality policies that set national commitments and goals towards gender equality, promote cross-cutting programmes (including society-wide awareness-raising and educational initiatives to challenge patriarchal attitudes and beliefs), and provide a national-level policy and institutional framework for mainstreaming gender considerations into the activities of all government agencies. Thus, for example, Guatemala adopted the Law on Dignity and Integral Promotion of Women in 1999, and under this law established in 2001 the National Policy for the Promotion and Development of Women, updated in 2007, and the Equal Opportunities Plan for 2001-2006, and then for 2008-2023. ${ }^{39}$

Unfortunately, but perhaps unsurprisingly, implementation of these gender policies has generally been weak. The key learning from the limited number of success stories is that the 'national machinery' dedicated to promoting these policies needs to be given sufficient status, power, and resources not only to implement its own cross-cutting gender programmes, but also to effectively influence the actions of other government departments (World Bank et al., 2009). While considerable challenges remain, the Philippines provides a good example of what can be achieved with sustained political and resource commitment, as Box 7 shows. 


\section{Box 7: Mainstreaming gender equality in the Philippines}

The Philippines government has made substantial progress in promoting gender equality over the past decade, ranking at number 12 out of 86 countries in the Social Institutions and Gender Index (SIGI) in 2012. This has been achieved through the government's commitment since 1997 to adopt gender mainstreaming as a national strategy, and its subsequent adoption of a range of laws and policies to make this a reality, including the adoption in 2009 of the progressive Republic Act 9710 (also known as the 'Magna Carta for Women'). A notable commitment to implementing these policies has been the introduction of gender budgeting, initially introduced under the Women in Development and Nation Building Act of 1992 and further cemented in the subsequent General Appropriations Act 1999. These Acts commit all government agencies to develop and submit annual gender and development plans and budgets as part of the general government budgeting process. Importantly, these laws also commit the government to allocating a minimum of 5 per cent of both national and local government budgets to the implementation of these gender plans. Furthermore, to support this process, the laws stipulate that the gender focal points established in agencies must be headed by a relatively high-ranking official, and central technical guidance has been developed to assist technical staff in developing and preparing these gender plans and budgets. While this policy has by no means been a runaway success, by 2004 a majority (61 per cent) of the key implementing agencies were submitting gender and development plans and reporting on their implementation and, in terms of impact on the ground, a number of impressive success stories exist.

Sources: Philippines case study report; Social Institutions and Gender Index (2012c); Asian Development Bank et al. (2008)

\subsection{VOICE AND PARTICIPATION IN POLICY DESIGN AND IMPLEMENTATION}

The country studies stress the importance of smallholder men and women's voice in policy design and implementation. The Tanzania study observed the 'overall lack of inputs in forms of ideas of smallholder farmers in general and women in particular in the process of formulation, implementation, monitoring and evaluation/review of policies. The processes are not participatory enough to capture the views, outcries, concerns, frustrations and other burning issues of representative smallholder farmers in general and women in particular. These are processes that typically take place in urban ministries' offices, and hotels in male-dominated decision-making environments where voices of smallholder farmers in general and women in particular are not adequately represented, if at all.'

Similarly, the Nigeria report speaks of the non-involvement of representatives of smallholders and women in agricultural policy decisions - such as the Association of Small-Scale AgroProducers in Nigeria (ASSAPIN) and the Nigerian Women Agro-Allied Farmers Association (NIWAAFA) - especially considering their centrality to employment and income generation. ASSAPIN and the Voices for Food Security coalition in Nigeria have developed a framework for engaging in the design (review) and implementation of the Agricultural Transformation Agenda. The Nigeria report also stresses that a participatory framework for agricultural policy design and implementation should extend to small-scale traders and processors, such as the National Association of Nigerian Traders (NANT) and women involved in marketing associations.

These barriers to voice and participation are slowly being broken down, and in more recent times some smallholder farmers' organizations and civil society organizations (CSOs) (such as MVIWATA and ANSAF in Tanzania), as well as some members of parliament, are 'increasingly 
echoing the voices of smallholder farmers in the corridors of power where policies are made and reviewed'. ${ }^{40}$

One of the core strategies for Oxfam's Gendered Enterprise and Markets initiative ${ }^{41}$ is improved capacity and space to shape market governance. In Ethiopia, this operates at two levels. Firstly, a private, public, and producer stakeholder forum, at regional and zonal levels, has been established, ensuring a 'seat' for primary producers and women's organizations. The regional forum, chaired by the Cooperatives Promotion Agency, paved the way for improving coffee quality to meet export standards and enter into the international specialty coffee market. At national level, Oxfam, working with the agricultural ministry, established a national forum where women and smallholders can discuss various constraints and issues with key decision and policy makers. In Tanzania, there was a pre-existing functioning body, the Sisal Board, which has made space for smallholders' and women's representatives, while also brokering contractual arrangements and disputes between companies and producers.

While exclusion of women farmers' voices from policy-making processes is still the norm, the case studies point out that promising exceptions to this rule are emerging. Thus, in Guatemala, the 1999 Law on the Dignity and Integral Promotion of Women, which aims to protect the fundamental rights of women guaranteed by national and international law and to promote the participation of women at all levels of economic, political, and social development, was the result of consultations with more than 10,000 women. Furthermore, the 2001 National Policy for the Promotion and Development of Women, and the Equal Opportunities Plan 2001-2006, were the result of a broad national consensus with a number of women's organizations, updated in 2007 with the participation of various sectors, government institutions, donor agencies, and CSOs. ${ }^{42}$

But creating policy space without capacity building to effectively use that voice is not enough. The East African members of a Learning Network on smallholder agency noted that, even though there is room for smallholder participation in many policy processes in the region, they are rarely mobilized for this role. ${ }^{43}$ Representation without knowledge-based advocacy can result in oppositional politics or misrepresentation of small-scale producers by CSOs. The experience of Guatemala's Project Initiative 40-84 demonstrates how (see Box 8). Furthermore, accountability mechanisms through which farmers' organizations can hold governments accountable for their policies and spending are critical to allow for effective voice and participation.

\section{Box 8: Voice and participation in implementing Guatemala's Measure 40-84 (National Integrated Rural Development Law)}

Guatemala's new government in 2012 proposed to develop a plan to run the national policy on rural development, which was approved in May 2009 by consensus between the previous government and more than 25 organizations from agricultural, peasant, and women's movements. The policy prioritizes gender equity and agricultural policy measures, such as allocation of land for farmers with priority to women heads of household, allotment of land to indigenous communities, provision of credit at preferential rates, and long-term land leases. The ruling party of the current government began a process of consultation with various organizations to hear their arguments for and against the law, known as the 40-84 Initiative. However, the split between small farmer and agroindustrial interests means that the promotion of integrated rural development in practice has had little momentum. This evidence suggests that integrated rural development is found more in the discourse of governments rather than in their actions.

Source: Guatemala country study 


\subsection{SUMMARY OF KEY FINDINGS, SECTION 2}

Good policies for inclusive agricultural investment and market governance are built on foundations of investment in small-scale agriculture - both in physical infrastructure and services tailored to the needs of women to allow smallholders to invest in cash and food crops, and in the policy infrastructure that addresses biases against small-scale farmers and women and which provides voice and participation, with the capacity to use them. Without these basic investments, commercial agricultural investment is likely to drive a two-tier agricultural development, with commercial farms as outposts of global agribusiness operating in isolation from the majority of smallholdings on the economic and political margins. These basics that can influence agricultural investment either in support of agro-industrial development or in support of smallholders and women are summarized in Table 2.

Table 2: The basics

\begin{tabular}{|c|c|c|c|c|}
\hline \multirow[t]{2}{*}{ Policy lever } & \multicolumn{3}{|l|}{ Policy intent } & \multirow{2}{*}{$\begin{array}{l}\text { Implementation } \\
\text { issues }\end{array}$} \\
\hline & $\begin{array}{l}\text { Policies that } \\
\text { favour large- } \\
\text { scale agriculture }\end{array}$ & $\begin{array}{l}\text { Policies that } \\
\text { support } \\
\text { smallholders }\end{array}$ & $\begin{array}{l}\text { Policies that } \\
\text { support women }\end{array}$ & \\
\hline $\begin{array}{l}\text { Agriculture } \\
\text { within wider } \\
\text { development } \\
\text { policies }\end{array}$ & $\begin{array}{l}\text { Business- } \\
\text { friendly } \\
\text { reforms (often } \\
\text { promoted by } \\
\text { donors) } \\
\text { - Focus on } \\
\text { PPPs }\end{array}$ & $\begin{array}{l}\text { Policies that } \\
\text { explicitly } \\
\text { support } \\
\text { smallholders }\end{array}$ & $\begin{array}{l}\text { - Policies that } \\
\text { increase } \\
\text { women farmers' } \\
\text { access to } \\
\text { extension, } \\
\text { credit, inputs } \\
\text { - Focus on crops } \\
\text { traditionally } \\
\text { grown by } \\
\text { women }\end{array}$ & $\begin{array}{ll}\text { - } & \text { Budget } \\
\text { allocations do } \\
\text { not reflect policy } \\
\text { intent } \\
\text { - } \quad \text { Lack of relevant } \\
\text { targets } \\
\text { - } \text { Implementation } \\
\text { biased towards } \\
\text { large farms }\end{array}$ \\
\hline $\begin{array}{l}\text { Infrastructure } \\
\text { and } \\
\text { institutions }\end{array}$ & $\begin{array}{l}\text { - Urban } \\
\text { infrastructure } \\
\text { bias }\end{array}$ & $\begin{array}{ll}\text { - } & \text { Extension } \\
\text { services } \\
\text { - Access to } \\
\text { market } \\
\text { information } \\
\text { - Access to } \\
\text { finance for } \\
\text { smallholders }\end{array}$ & $\begin{array}{l}\text { Female } \\
\text { extension } \\
\text { workers } \\
\text { - Policies that } \\
\text { encourage } \\
\text { flexible } \\
\text { collateral, } \\
\text { gender- } \\
\text { sensitive } \\
\text { applications } \\
\text { - Infrastructure } \\
\text { that frees up } \\
\text { women's time, } \\
\text { e.g. water }\end{array}$ & \\
\hline $\begin{array}{l}\text { Cross-cutting } \\
\text { gender laws } \\
\text { and policies }\end{array}$ & & & $\begin{array}{l}\text { - Gender equality } \\
\text { policies, } \\
\text { including in } \\
\text { family and } \\
\text { inheritance law }\end{array}$ & $\begin{array}{l}\text { - Status and } \\
\text { resources of } \\
\text { 'national } \\
\text { machinery' to } \\
\text { implement laws }\end{array}$ \\
\hline $\begin{array}{l}\text { Voice and } \\
\text { participation }\end{array}$ & $\begin{array}{l}\text { Policy making } \\
\text { in urban } \\
\text { ministries and } \\
\text { male- } \\
\text { dominated } \\
\text { environments }\end{array}$ & $\begin{array}{l}\text { Participatory } \\
\text { framework } \\
\text { including } \\
\text { small-scale } \\
\text { traders and } \\
\text { processors }\end{array}$ & $\begin{array}{l}\text { Participatory } \\
\text { framework, } \\
\text { including } \\
\text { women }\end{array}$ & $\begin{array}{l}\text { - Lack of } \\
\text { mobilization and } \\
\text { capacity } \\
\text { building }\end{array}$ \\
\hline
\end{tabular}


Significant common features of policy frameworks today are creating incentives for large-scale land acquisitions for plantation agriculture, and against models of agricultural investment that are inclusive of small-scale producers. Despite much diversity in local contexts, Section 3.1 charts these features, while Section 3.2 discusses policy levers that can promote more inclusive investment models.

\subsection{WHICH POLICY LEVERS CURRENTLY FAVOUR LARGE-SCALE INVESTMENTS?}

\section{Investment promotion policies}

Over the past two decades, governments all over the world have taken steps to promote investment, including in agriculture. Measures include investment codes, sectoral policies (for instance, on biofuels), and a web of over 3,000 investment protection treaties worldwide. Overall, investment promotion policies create powerful incentives that favour large-scale investments, including large land deals, over more inclusive investment models. While there is much diversity in the approaches pursued, investment promotion policies tend to involve varying combinations of the following measures.

- Investment liberalization: This often involves national law reforms, for instance to ease or lift government approval requirements on foreign investment. Bilateral and multilateral trade and investment treaties have also promoted investment liberalization. For example, under the 2004 Free Trade Agreement between the United States, the Dominican Republic, and the Central American Free Trade Area (CAFTA) - a treaty commonly known as CAFTA-DR - foreign investment enjoys, in almost all circumstances, the right to establish, acquire, and operate investments in other countries on an equal footing with national investors.

- Investment facilitation, for instance though simplifying administrative procedures and establishing 'one-stop shops' to help investors obtain the necessary permits and licences from relevant government departments: in Lao PDR, for example, the Investment Law of 2009 established a one-stop shop to provide investors with information, consider investment applications, issue relevant administrative certificates, and help investors liaise with other government departments. ${ }^{44}$ Other countries with investment promotion agencies promoting investment in land include Sierra Leone, Senegal, Zambia, and Tanzania (see Box 9) (Oxfam, 2012).

- Investment protection: In Cambodia, Guatemala, and Tanzania, for example, investment codes restrict the power of the government to expropriate investments. ${ }^{45}$ Many investment codes also prohibit discrimination between national and foreign investors, and allow investors to bring disputes to international arbitrators, rather than national courts. International investment treaties specifically protect foreign investment. They commonly restrict discrimination and expropriation, require governments to treat investors in a 'fair and equitable' way, allow free repatriation of profits, and provide access to international arbitration.

- Investment incentives: These include competitive tax regimes, including low corporate tax rates, tax exemptions and holidays, and capital allowances. In Guatemala, for example, legislation on bio-ethanol and renewable energy exempts producers from paying value added tax (VAT) and import duties on machinery and equipment for specified periods of time. In Peru, the Foreign Investment Law and the Private Investment Law of 1991 guarantee stability of the tax regime applicable to investments. ${ }^{46}$ 
In Zambia, promotion of private investment in agriculture is a central part of government efforts to promote agricultural development, supported by the World Bank's Investment Climate Advisory Service. Investment legislation includes a number of general safeguards for investors: free repatriation of net profits and debt payments; safeguards on investment protection, including full compensation based on market value in the case of expropriation; and facilitation services provided by the Zambia Development Agency, e.g. in obtaining permits and licences necessary to operate the business. Tax incentives are also provided. These include a corporate income tax set at 15 per cent, tax holidays on corporate income tax and on taxation of dividend payments, duty-free importation of most capital equipment for agriculture, and capital allowances for certain types of expenditure.

The Tanzania Investment Act of 1997 allows free repatriation of profits and debt payments, restricts and regulates the expropriation of protected investments, and allows investors to bring disputes with the government to international arbitrators, rather than national courts. ${ }^{47}$ It also established the Tanzania Investment Centre (TIC) to function as a onestop shop in relations between investors and government, e.g. by helping investors to obtain necessary licences and permits from relevant government authorities. The TIC has also been supported by the World Bank.

Tanzania's tax law also features a number of tax incentives for investors. For all investors holding a 'certificate of incentives' issued by the TIC, these include duty-free importation of capital equipment for agriculture and farm inputs, exemption from VAT on agricultural inputs (e.g. fertilizers, pesticides), and capital allowances for certain types of capital expenditure. Additional tax incentives are available to investors operating in Export Processing Zones and Special Economic Zones, while companies with 'strategic investor' status (i.e. investing more than $\$ 20 \mathrm{~m}$ ) can negotiate tailored fiscal regimes.

According to the UNCTAD database of treaties, Tanzania has signed 15 bilateral investment treaties ${ }^{48}$ and ten double taxation agreements. ${ }^{49}$

Sources: Mujenja and Wonani (forthcoming); Tanzania country report and official documents.

Investment treaties aim to protect foreign investment. But while a few national investment codes apply only to foreign investment (e.g. Guatemala's Foreign Investment Act of 1998), most codes cover both foreign and domestic investment ${ }^{50}$ - although the focus is typically on largescale investment. Minimum size requirements may make this explicit. For example, the Tanzania Investment Act of 1997 applies only to investments above $\$ 300,000$ for foreign investors and $\$ 100,000$ for domestic ones. ${ }^{51}$ Similarly, Mozambique's investment legislation applies to investments approved by the government, ${ }^{52}$ with a minimum value of $\$ 5,000$ for nationals and $\$ 50,000$ for foreigners. ${ }^{53}$ These thresholds are prohibitive for the vast majority of rural dwellers in these countries. In other cases, investment legislation contains no minimum value but requires government approval as a precondition for access to the protection, facilitation, and incentives provided. Therefore, these benefits are unlikely to apply to the economic activities of local groups, which involve investment but tend to be for relatively small monetary values and are unlikely to seek government approval. Small-scale producers are in effect excluded from the application of this legislation, though compared with agribusiness they are in effect also less subject to income taxation and administrative fees.

As far as investments above the minimum size are concerned, the measures apply both to those involving large plantations and to ventures that source agricultural produce from smallscale producers. But tax incentives for activities typically associated with the establishment of large farming operations, such as exemptions from customs duties for the importation of machinery, tend to favour large-scale farming. 


\section{Policies on land, water, and natural resources}

This section considers laws, regulations, and other policies that determine who has what types of rights to land, including the right to own, use, buy, and sell land. Several policy levers in this area favour large land deals over more inclusive models.

Land tenure is a case in point. Land policies vary considerably in different countries and regions. In Africa, land legislation is still influenced by historical legacies rooted in the colonial experience and in post-independence political choices. At least on paper, central governments tend to claim a significant degree of control over much rural land. In Tanzania and Mozambique, ownership of all land is vested with the president as a trustee for the nation. Other countries have enabled or even promoted private land ownership - Kenya, Ghana, and Mali, for example. But with a few exceptions, private land ownership tends not to be widespread even where it is formally recognized, particularly in rural areas. Long and cumbersome registration procedures mean that few rural dwellers have access to land ownership. And because in many jurisdictions all untitled land is owned or otherwise held by the state, governments end up controlling much rural land, even where the statute books devote numerous provisions to regulating private ownership. To villagers, the land they have used for generations is theirs. But, legally, the land is owned by the government, which has the legal authority to allocate it to largescale investors.

On land owned by the state, the protection of local land rights is often weakened by a number of characteristics commonly found in relevant laws and policies. Firstly, local populations often have legal claim only to land that is in 'productive use', which undermines local claims to rangelands, hunting-gathering grounds, sacred sites, and land reserves set aside for future generations lands that are often traditionally managed as common property resources. This criterion also has important gender implications, since women tend to rely more than men on communal 'nonproductive' lands for their livelihoods, and therefore tend to suffer disproportionately from loss of access to these lands. For example, recent studies in Ghana and Zambia found that, as in many other developing countries, women rely much more heavily than men on the collection and sale of wild products from communal land for income generation. In consequence, the lease of large tracts of communal land by a number of large-scale investment projects has had a greater negative impact on women than on men. Among other negative impacts, women now have to walk longer distances to collect the products that they previously obtained from the leased land, and thus have (even) less time to spend on agricultural and other income-generating activities (Bugri and King, forthcoming; Wonani et al., 2012).

The protection of local land rights is also weakened by wide state powers of eminent domain (whereby investment projects are considered to be for a 'public purpose' that enables the compulsory taking of local rights); weak compensation requirements that limit compensation for improvements such as trees and crops, to the exclusion of land values; and absent or inadequate local consultation requirements. Progressive law reforms have been enacted to secure local land rights in countries such as Mozambique, Tanzania, and Uganda. But implementation has often fallen short of expectations (see below).

State control over land and weak local land rights create real risks that local people are marginalized in decision making and are vulnerable to dispossession. These features also make it easier for investors to acquire large areas of land through a single deal. A World Bank study found a statistically significant correlation between weak protection of local land rights and the scale of land acquisition. It also documented widespread use of expropriation to pave the way for large plantations (Deininger et al., 2011). Governments have deployed an array of legal arrangements to facilitate access to land for investors (see Box 10). 
In Tanzania, government efforts to facilitate land access for investors must take into account the fact that much of the country's land is under the control of village authorities. Three main legal routes have been established to enable investors to access land. The first involves obtaining from the central government a 'granted right of occupancy' on 'general land' - i.e. the land area that is under direct management by the central government. This route is the most commonly used mechanism for land acquisition for large agricultural investments. However, only about 2 per cent of the country is classified as 'general land', so this route typically involves first transferring land from 'village land', which is managed by village authorities, to 'general land'. A compulsory transfer would have to be justified by a public purpose and accompanied by the payment of compensation. However, the law explicitly states that investments of national interest constitute public purpose.

Also, the definition of 'general land' is different in the two relevant national laws, despite the fact that these laws were adopted on the same day. While the Village Land Act of 1999 makes a neat distinction between village and general land, the Land Act of 1999 defines 'general land' as also including those village lands that are 'unoccupied or unused'. The law does not define what constitutes use or occupation, but Tanzanian legal experts say that these concepts are usually interpreted as requiring evidence of visible 'unexhausted improvements' - in other words, crops, buildings, or fences. This interpretation can undermine the rights of pastoralists and hunter-gatherers, whose resource use often does not result in visible improvements. It can also undermine local rights to fallow land and to land reserves set aside for future generations. So land that villagers consider to be part of village land may end up being deemed to be 'general land' instead, and on that basis may be allocated to commercial investors.

The second route developed to facilitate access to land for investors involves obtaining a 'derivative title' from the Tanzania Investment Centre (TIC). Given the small share of 'general land' under direct central government control, the TIC has sought to establish a 'Land Bank' to promote investor access to village lands. The Land Bank is effectively a database of land deemed to be 'available' for allocation to investors. As of 2005, some $2.5 \mathrm{~m}$ hectares of land were included in the Land Bank, though the initiative seems to have lost steam, and the lands identified seem too fragmented and scattered to be of interest to investors. Supported by the World Bank, the original idea was that title on these lands would be vested with the TIC, and that the TIC would then sub-lease the land to investors. But this does not seem to have happened. Effectively, the Land Bank operates only as a database and a source of information, rather than a source of derivative titles. Only some 50,000 hectares of land were found to have been allocated through this route.

The third route involves deals with Tanzanian citizens, rather than with the government, for example in the form of sub-leases and joint ventures. However, this route does not seem to have been much used by large investment projects.

Sources: Land Act of 1999, Village Land Act of 1999, Tanzania Investment Act of 1997; and Tanzania country study

In order to attract investment, governments have been prepared to allocate land for very low fees - and some deals do not require payment of any land fees at all. The possibility for companies to obtain large areas of land in exchange for little in the way of monetary payments creates a powerful incentive that favours large plantations over other investment models. Most analysts expect land values in Africa to increase significantly in the coming years, and land appreciation is an important source of revenues in the business model of many agricultural ventures. 
Similar considerations may be made with regard to the allocation of water rights. Over the past two decades, water law reforms across the world have abolished or eroded private water rights, and have brought water resources under state ownership or control. Water rights are then allocated by government authorities through administrative processes, with exemptions for domestic use or use below specified quantities. This is to enable flexible water use planning and to promote efficient and sustainable water use. So where small-scale producers hold legally protected rights to a piece of land, they usually do not have formal rights to the water flowing through or by that land.

Governments have the power to allocate water rights, and they commonly do so through contracts for large plantations. Some land deals, e.g. in Senegal, allocate water rights without payment of any water fees (Cotula, 2011). In contrast, neighbouring small-scale farmers on publicly owned irrigation schemes would be legally required to pay water fees or lose their irrigated plot. Also, some contracts give large-scale investments priority in water access over small-scale producers, which creates real risks for small-scale producers in times of water shortage. ${ }^{54}$

Giving large-scale investors legal rights and priority over water access can have particular gender implications, since women tend to have primary responsibility for collecting water for domestic use (and in some societies, also for livestock use). Where investment projects put pressure on local water sources, women often have to travel further to collect potable water, thus adding to their daily workload and further reducing the amount of time they have to spend on agricultural activities (Daley, 2011; Behrman et al., 2011).

The negotiation of large land deals usually happens behind closed doors. Only rarely do local land users have a say in those negotiations. Few contracts are publicly available. This limited transparency and public accountability creates a breeding ground for corruption and for deals that do not maximize the public interest. They facilitate large-scale land acquisitions for speculative purposes, and also undermine the ability of local groups to be meaningfully informed when local consultations occur. In the words of the Tanzania report:

'An absence of legal provisions for transparency in land deals means that it is almost impossible for the public to access information about investments. Such information includes but is not limited to who is involved, who was informed, what amount of land was acquired, for how long, for what purpose and for implications/impacts on villagers in general and smallholder farmers in particular.'

Similar trends - state ownership, weak local rights, mechanisms to facilitate land access for large-scale investments - are seen in parts of Southeast Asia, e.g. Lao PDR and Cambodia. But the context of land and resource governance is very different in other parts of the world. In Latin America, for example, private land ownership is widespread. Land also tends to be distributed very unequally. To reduce concentration in land ownership, many countries have adopted redistributive reforms that favour small- over large-scale farming, but there are signs that the trend towards land redistribution may now be reversing. These issues are discussed in the following section. 


\subsection{WHAT HAS WORKED AND WHAT HAS FAILED AROUND THE WORLD IN SUPPORTING INCLUSIVE INVESTMENT?}

Overall, important aspects of the policies that regulate investment promotion and land tenure are creating strong incentives that favour large land deals over more inclusive models of agricultural investment. But other policy levers favour investment models that support smallscale producers. This section briefly reviews experience with these policies, including successes and failures. It also discusses possible policy approaches that are still to be properly tested.

\section{Local control over land and resources}

Control over land is critical. Much experimentation with more inclusive models is happening in countries where land policy has created strong incentives for businesses to work with local groups. In South Africa, for example, the land restitution process involves the restitution of lands to communities that were dispossessed as a result of colonial and apartheid policies. As land changes hands from companies to local communities, companies are forced to work with the new landowners to keep their businesses going (Makhathini, 2010; Lahiff et al., 2012).

Measures to increase local control over land and natural resources are of two different kinds: land redistribution and land tenure reform. Both sets of measures may be relevant to the same country, though as a broad generalization redistributive reforms are particularly relevant to Latin America, Southern Africa, and parts of South and Southeast Asia, where land ownership has traditionally been strongly concentrated.

In Latin America, there is longstanding experience with redistributive reform. In Brazil, for example, the agrarian reform programme was set up by the Land Statute of 1964, which enabled land expropriation and distribution by a public body. Agrarian reform has subsequently been the object of vast amounts of legislation, including the Agrarian Law of 1993 and various amendments to accelerate the process. And in addition to the federal agrarian reform programme, some states in the northeast of the country have adopted state agrarian reform programmes based on the 'willing seller, willing buyer' principle. ${ }^{55}$ The extent of progress in recent years has been contested, with the government painting a positive outlook ${ }^{56}$ and advocacy groups arguing that land concentration has increased in recent years. ${ }^{57}$ Land distribution in the country remains among the most unequal in the world. In Asia, the Philippines has a long history of agrarian reform programmes. The most recent one is the Comprehensive Agrarian Reform Law with Reforms (CARPER), which builds on two earlier programmes - the Comprehensive Agrarian Reform Law of 1988 and a programme initiated in 1972. However, progress in implementation, particularly of land distribution, has been slow.

Where properly implemented, redistributive programmes tend to promote models of investment that are inclusive of small-scale producers, as the land is in the hands of these producers. But there are signs that the trend toward land redistribution may now be reversing. New processes of concentration are under way in some areas where land has been redistributed. Policy levers are making this reversal possible. In Guatemala, for example, the 1999 Land Fund Act established financial mechanisms to help small-scale producers obtain access to land ownership. Although this was established after the Peace Agreements, and lands have been distributed to landless peasants, it never really had a significant effect on reversing land concentration. The fund allows both individual and collective land ownership, ${ }^{58}$ but the granting of full ownership rights to beneficiaries, and the preference for individual rather than family ownership, have resulted in many new landowners selling out to large-scale oil palm and sugar cane growers. In Petén department, an estimated 30 per cent of farmers have sold their land, involving a total of over 60,000 acres. 
In Africa, a critical policy issue affecting local control over land relates to the legal protection of local land rights. As discussed above, much land in Africa is owned by the state. But some countries have taken steps to strengthen the protection of customary rights, which are the main mechanisms through which rural people access land. Customary rights are, for instance, legally protected in Mali, ${ }^{59}$ Mozambique, ${ }^{60}$ Tanzania, ${ }^{61}$ and Uganda ${ }^{62}$ In these countries, legislation enables local landholders to formally record their customary rights. However, recognizing the difficulties experienced by many small-scale producers in recording their land rights, some laws protect local rights even if they are not formally registered - for example, in Mozambique. Mozambique's legislation protects and allows for the registration of the land rights of legally defined 'local communities'. And while customary land rights are often treated as having lesser status than the land rights granted by the government, legislation in Tanzania and Mozambique grants customary rights the same legal status available to other land rights. ${ }^{63}$ Simple, low-cost, and accessible forms of land records have been introduced in several African countries, for instance systematic land registration programmes in the Ethiopian states of Amhara and Tigray, ${ }^{64}$ the plan foncier rural in Benin (Chauveau, 2004; Le Meur, 2006), and through the guichet foncier in Madagascar (Teyssier, 2010). Some legislation specifically recognizes the natural resource rights of pastoralists, including rights over their 'home areas' (terroirs d'attache, in $\mathrm{Niger}^{65}$ ) and the right to move livestock for transhumance purposes. ${ }^{66}$

On paper, this wave of legislation goes a long way towards strengthening local rights. Stronger rights in the hands of small-scale producers would create incentives for more inclusive investment models. In practice, however, these laws have had little impact on the ground. Some of the countries that have adopted progressive land laws have also been major recipients of large-scale land-based investments. Tenure reform has usually been cautious. With a few exceptions, governments have been reluctant to relinquish their ultimate ownership of the land, and in most cases local rights are protected as use rights only. This protection is often limited or qualified. For example, it is often conditioned to proof of productive use - a requirement difficult to meet, for example, for pastoralism and hunting-gathering. In some cases, the implementing regulations necessary to give effect to the new legislation have not been adopted - in Mali, for instance. Also, the implementation of legislation protecting local rights may not be assisted by the resources and political will required for these laws to make an impact. More than ten years since the enactment of Tanzania's Land Act and Village Land Act in 1999, only 850 villages have a certificate for their land under the Act, out of an estimated total of 11,000-14,000 villages; while estimates of the number of certificates of customary right of occupancy that have been issued under the Act range anywhere between between 14,000 and 165,000, of an estimated potential total of 8 million (TNRF, 2012).

Moreover, in the case of both land redistribution and land titling programmes, even relatively 'successful' programmes have mostly failed to reduce gender inequalities in access to land, and have often exacerbated these inequalities. This has for the large part been due not to direct discrimination, but to indirect discriminatory measures commonly adopted in these programmes. For instance, the criteria for land distribution under agrarian reform programmes, while not referring explicitly to gender equality, often refer to male-dominated categories such as permanent agricultural workers (while women are concentrated in the seasonal and temporary agricultural labour force) and smallholders (while women rarely own land) (e.g. Philippines, Brazil). Moreover, in the past, many land redistribution and titling programmes issued land titles in the sole name of the household head, who is usually (de jure or de facto) the husband/father (e.g. Kenya), with the result that women's secondary rights to land were typically ignored and not included in land registers (FAO, 2007b; World Bank et al., 2009). Furthermore, the bureaucratic procedures and paperwork required to register land can in themselves discourage or prevent many rural women from participating in land titling programmes, due to their high levels of illiteracy (World Bank et al., 2009).

Given that poor access to land is often the single most important constraint limiting women's ability to benefit from agricultural markets and investments, making land policies work better for women requires urgent attention. Some countries have embarked along this road. Many countries, including Tanzania and the Philippines (SIGI, 2012c and d), have amended their 
land tenure laws to include explicit guarantees for women to own land in their own right, for women and men to have equal rights to inherit land, and/or for women to buy and sell land without the need for consent from male relatives. With regard to land titling/registration and land reform policies, some countries, including Tanzania, have explicitly encouraged joint titling of land where both spouses work on the land, have supported female household heads to receive land titles in their own names, and/or have supported married women to gain sole title of land where appropriate (FAO, 2007b; World Bank et al., 2009).

Unfortunately, implementation of these policy elements has in general been problematic, in large part due to a lack of gender sensitivity on the part of the implementers and insufficient government resources and commitment to increase gender awareness in relevant government departments. In both Bolivia and Nicaragua, for example, despite very positive and specific language in the land titling legislation regarding women's and men's equal land rights, resistance from programme implementers and participant populations meant that the implementation of the titling programme resulted in the great majority of the land being titled to men (World Bank et al., 2009).

Furthermore, the implementation of gender-sensitive components of land laws and land titling and reform programmes has been complicated by the fact that they often conflict both with other statutory laws and policies (e.g. gender-biased family and succession laws) and, perhaps more importantly, with customary land tenure laws and practices (which are typically based on patriarchal attitudes and practices) (World Bank et al., 2009). The latter can be a particular problem where customary law is formally recognized and upheld by statutory land laws. For example, in Ghana national land tenure policies grant customary land authorities a high degree of power in making land allocation decisions, yet these authorities are almost always maledominated and perpetuate patriarchal land allocation practices (Bugri and King, forthcoming).

To reverse these negative trends, there is a need to strengthen implementation mechanisms and, where relevant, place appropriate checks and balances on customary land authorities. Some countries have recognized this need. For example, Ethiopia's land certification scheme introduced a low-cost, rapid, and transparent community land registration process in order to help ensure that it was accessible to illiterate rural women: the scheme led to increased confidence and tenure security of female heads of household. Moreover, in recognition of the importance of having female representation in local land committees, some countries, including the Philippines, Tanzania, and Rwanda, have introduced gender quotas for local land administration committees (World Bank et al., 2009; Philippines case study report). And in Guatemala, the Land Fund has adopted a number of measures that appear to have been successful in ensuring that women have benefited substantially from its programmes, as Box 11 shows. 
The Land Fund was established in 1999 to assist small-scale farmers to gain access to land, and provides financial support (through subsidies and loans) to help farmers either register existing land or purchase or rent new land. The Land Fund Law has from the outset included specific gender objectives and mechanisms, including a declaration that married women have full co-property rights and a provision for programmes to facilitate women's access to credit in order to buy land. Furthermore, the Land Fund established a women's unit responsible for promoting gender equality issues; among other activities, the unit developed a guide to improve the gender awareness of technical assistance teams. More recently, in 2010 the Fund's Board of Directors passed a specific gender equity policy, a significant aspect of which was that it changed the conditions for the formation of associative rural enterprises such that more women were to be elected to boards.

According to the country case study report, these efforts have paid off. Women have benefited almost equally as much as men from both the land rental and land registration programmes: of the 242,000 people benefiting from the land lease programme between 2007 and 2011, 52 per cent were women, and 50 per cent of the 30,252 people benefiting from the land registration programme during the same period were women. Significantly, however, women have been much more poorly represented in the land purchase programme, representing only 16 per cent of the 1,907 individual beneficiaries between 2007 and 2011. However, this may change following the passing of the 2010 gender policy and the resultant increase in the number of women involved in associative rural enterprises: the percentage of women participants increased from 15 per cent in 2008-09 to 48 per cent in $2010-11$.

Sources: Guatemala case study report; Grobakken (2005)

In relation to local control over land, another key aspect that needs to be considered is the extent to which local land users have a say in decisions affecting their land. In countries like Senegal and Tanzania, significant land management responsibilities have now been devolved to local governments, though the central government can compulsorily acquire land for a public purpose. Some countries require consultation of local landholders as a condition for investors to obtain land leases, e.g. Mozambique. ${ }^{67}$ International guidance also calls for local consultation, including the recently adopted Committee on World Food Security (CFS) Voluntary Guidelines on the Responsible Governance of Tenure of Lands, Fisheries and Forests in the Context of National Food Security (the CFS Guidelines) ${ }^{68}$ The CFS Guidelines also call for the negotiation of partnerships with local tenure right holders. ${ }^{69}$ International best practice increasingly points to the principle of free, prior, and informed consent (FPIC) - whereby local land users have a right to say 'yes' or 'no' to proposed development projects. According to one definition, FPIC is the principle that project approval is subject to 'negotiated agreements that are non-coercive and entered into voluntarily, carried out prior to new investments or operations based on an open sharing of all relevant information in appropriate forms and languages, including assessments of impacts, proposed benefit sharing and legal arrangements'. ${ }^{70} \mathrm{FPIC}$ is also an ongoing process, since projects take many years to plan and implement, and the principle applies throughout the whole process. ${ }^{71}$ Indigenous peoples in particular have the right to FPIC, but in recent years the principle has increasingly been used in relation to groups that do not qualify as indigenous peoples under international law. ${ }^{72}$ While FPIC requirements are still rare, they have gained increasing currency in recent years. Today, FPIC requirements are included in international law and in lender and industry standards, as well as in some national legislation, e.g. in the Philippines (see Box 12).

Increasing local voice in decision making would tend to favour investment models that support small-scale producers, as these would need to make recommendations or even approve the proposed project. A World Bank report found that more land had been acquired in Mozambique than in Tanzania in the period 2004-09, and attributed this finding to Tanzania's devolution of 
land management powers to local government bodies (Deininger et al., 2011). But formal consultation or consent requirements have displayed only limited effectiveness in making local voices heard. In Mozambique, local consultation exercises often involve one-off meetings with local elites; women are often excluded; and the result is a report, not a binding contract that would enable communities to hold the investor to account for the promises made. ${ }^{73}$

Shortcomings have also been documented in the implementation of FPIC requirements in the Philippines (see Box 12). Having rights on paper and being able to exercise them effectively often do not go hand in hand, especially where major power imbalances exist, information about proposed projects is very limited due to lack of transparency, and local capacity to negotiate effectively with government and investors is limited. Moreover, as was the case in Mozambique, women farmers are even less likely than men to be part of the negotiations, since women are rarely represented in local elites/traditional leaderships, and are also less likely than men to be recognized as land holders (Norfolk and Tanner, 2007).

\section{Box 12: Free, prior, and informed consent in the Philippines}

Giving effect to constitutional provisions, the Indigenous Peoples Rights Act of 1997 recognizes indigenous peoples' right to self-determination, to the legal protection and collective titling of 'ancestral domains', and to the application of customary rules in the management of land and natural resources. At the same time, the Act guarantees gender equality and the human rights of indigenous women, balancing the recognition of indigenous peoples' autonomy with the protection of universal human rights.

The Act specifically recognizes the right of indigenous peoples to express their free, prior, and informed consent with regards to proposed development projects, such as mining, infrastructure, and renewable energy, within their ancestral lands and domains. ${ }^{74} \mathrm{FPIC}$ is defined as meaning 'the consensus of all members of the [indigenous peoples] to be determined in accordance with their respective customary laws and practices, free from any external manipulation, interference and coercion, and obtained after fully disclosing the intent and scope of the activity, in a language and process understandable to the community'. $^{75}$

Some commentators have noted that, despite the progressive nature of this statute, much law remains unfavourable to indigenous peoples. Legislation passed by the Spanish and US colonizers vested much land claimed by indigenous people with the state, and the constitution confirms this (Cariño, 2005). The Act itself sets out that rights already allocated within ancestral domains are confirmed and respected. ${ }^{76}$

Also, the implementation of FPIC requirements has fallen short of expectations. Mining developments in particular have tested legislation on FPIC. Research shows that in many cases the required procedures have not been respected, the information disclosed was biased, and consent was engineered. ${ }^{77}$ These problems result from power imbalances, but also from lack of the necessary resources and community facilitation skills in relevant government departments (Co, 2008).

Despite this disappointing track record, there are also encouraging experiences where local consultation has made a difference. In the case of Guatemala, many families in communities have sold their land for palm oil plantations and sugar cane, in exchange for unfulfilled promises of jobs and improvements to their communities. The few families who have not sold their land have been surrounded by palm plantations or cane. However, despite the intimidation, pollution, and poor conditions in which they live, these families have decided not to leave their land because they have strengthened community agriculture as a source of income generation, and the land is all that their children will inherit. ${ }^{78}$ Appropriate support from government and development agencies and adequate access to information are critical to community agency and empowerment. 
In addition to national policy and processes, international law - particularly human rights law offers levers for local groups to assert control over their land. While a 'human right to land' as such has no basis in international law, several human rights are directly relevant to land rights. Even where local land rights are based on customary systems that have no legal recognition, they constitute 'property' protected by the human right to property. This right is internationally recognized, for instance, by the Universal Declaration of Human Rights, the American Convention on Human Rights, and the African Charter on Human and Peoples' Rights. International human rights bodies have made it clear that the right to property protects collective rights held under customary law. Where people depend on land for their food security, local land rights are also protected by the right to adequate food. Local people faced with the threat of expropriation from mining and logging have successfully brought their cases to the InterAmerican Court of Human Rights, ${ }^{79}$ and more recently to the African Commission on Human and Peoples' Rights. ${ }^{80}$

However, remedies under international human rights law remain largely ineffective. If human rights petitioners win a case, the ruling may have limited legal or practical force. For example, the African Commission on Human and Peoples' Rights issues only non-binding decisions. The recently established African Court on Human and Peoples' Rights issues binding judgements, but only about half of African states are parties to the Court's Protocol. This situation contrasts with the much more effective remedies established in international law for the protection of foreign investment, including binding and widely enforceable arbitral awards (Cotula, 2012).

\section{Land access conditions}

Tighter terms and conditions on large-scale operators acquiring land can create greater incentives for investors to consider less land-intensive business models. Relevant mechanisms range from restrictions on foreign land ownership through to proper land valuation. For example, charging adequate prices for land allocated to prospective investors would reverse the current trend whereby much land is given out for low or even no fees, and it would create greater incentives for investors to consider alternative business models. The CFS Guidelines refer to safeguards in the form of ceilings on permissible land transactions and parliamentary approval of land deals above a certain size. ${ }^{81}$

Some countries restrict the acquisition of land ownership or of long-term use rights by foreigners. In Ghana, for instance, while nationals may own land, foreigners may not - they can only acquire land leases of up to 50 years. ${ }^{82}$ Under Uganda's Land Act of 1998, non-citizens may only be given land leases for up to 99 years, and are barred from acquiring freehold rights. ${ }^{83}$ Similarly, in the Philippines, the Constitution of 1987 does not allow foreign land ownership, but foreign investors can lease landholdings for a maximum of 25 years, renewable for another 25 years, without limits as to their size. Other countries do not have these restrictions. In Cameroon and Mali, for example, both nationals and non-nationals can own land. It should be pointed out, however, that the practical implications of long-term leases may not be very dissimilar from those of land purchases, in that several generations of local farmers will be excluded from the land. Also, there has been a longstanding global trend towards the easing and removal of these restrictions.

More recently, however, concerns about 'land grabbing' have induced some countries to regulate the acquisition of land rights by foreign nationals in stricter terms or to freeze deals until the situation can be brought under control and the impacts fully understood. In 2011, The Democratic Republic of Congo introduced strict nationality requirements, whereby only Congolese citizens or companies that are majority-owned by Congolese nationals are allowed to hold land..$^{84}$ Argentina has also introduced restrictions, but has adopted a different approach. Law No. 26.737 of 2011 limits 'ownership by foreigners (both individuals and companies) to 15 per cent of productive rural land, a restriction that is compounded by a limit of 30 per cent for foreigners of the same nationality. In addition, no single foreign person or firm may own more than 1,000 hectares of land in certain core productive districts' (UNCTAD, 2012). In May 2012, 
after the killing of a local activist and a wave of public protests, Cambodia halted new land concessions. $^{85}$

\section{Investment regulation}

Policies to manage investment can also play an important role in encouraging more inclusive investment models. Effective scrutiny of investment proposals for large plantations, covering both feasibility and impact assessment, is critical. Environmental legislation adopted in many developing countries since the 1990s requires environmental and social impact assessments to be carried out before an investment project is approved. ${ }^{86}$ Impact assessments can provide an important mechanism for scrutinizing proposals for large agricultural investments, especially where local or public consultation requirements apply. ${ }^{87}$ Beyond the scrutiny of investment proposals, effective monitoring of approved investments is also important to ensure that investment plans with inclusiveness features are complied with. But scrutiny of investment proposals and implementation is a notoriously challenging area. For example, shortcomings in the application of this environmental legislation within the context of large plantation projects have been widely documented. Implementation of some investments has started without the required environmental permits, while in other cases assessment or consultation processes have proved deficient. ${ }^{88}$

From a gender equality perspective, strengthening screening and monitoring policies is a prerequisite for promoting more gender-equitable outcomes from large-scale agricultural investments. In addition, however, specific gender-sensitive screening and monitoring criteria need to be incorporated into these policies and processes, in order to counteract the typically gender-inequitable impacts of large-scale investments. Unfortunately, the research for this report could not identify any existing national investment policies that address these concerns. However, experience would suggest that investment proposals should be screened according to the extent to which investors plan to include women in consultation and negotiation processes, to ensure that compensation and resettlement schemes are designed to benefit women as well as men, and to ensure that mitigation plans effectively address the potential negative impacts of the investment on women. Importantly, consideration should also be given to the proposed business model and the extent to which it is likely to benefit women as well as men farmers (Bugri and King, forthcoming; Wonani et al., 2012).

Of equal importance is the incorporation of gender-sensitive performance criteria into the monitoring procedures governing investors' behaviour (e.g. environmental impact assessments). These criteria might include the percentage of participating smallholders who are female, the percentage of small-scale producer board representatives who are female (where relevant), and the ratio of female to male income among smallholders participating in the scheme.

In addition to establishing appropriate screening and monitoring mechanisms, policy can also promote inclusive investment in more direct ways. The CFS Guidelines call on governments to 'support investments by smallholders as well as public and private smallholder-sensitive investments'. ${ }^{89}$ This may include, for example, tax incentives for investments that source produce from small-scale producers or involve them as shareholders in the business venture, reversing biases in current tax incentive regimes that favour the importation of machinery and capital equipment. Research for this report could not identify tax incentives framed in this way but there is relevant experience that could be monitored and built upon. For example, Nigeria has adopted policies to encourage investment by small-scale producers. The Nigerian government recently announced tax holidays for investors who set up processing plants in staple crop processing zones. This could create positive incentives for small-scale farmers supplying agricultural commodities to the processing plants. Moreover, Nigeria has a policy whereby revenue derived from increased levies on agricultural commodity imports should be used to support domestic production. If this policy is effectively implemented, it is likely to be an incentive for small-scale farmers to increase production of the commodities involved, especially rice, maize, and wheat. 
In addition to tax incentives, other policy measures may also create incentives for models of agricultural investment that include small-scale producers. For example, stricter labour legislation, coupled with collective action, would tend to encourage a shift away from plantations. ${ }^{90}$ Public investment in R\&D and in rural infrastructure and services, whether specific to agriculture (e.g. storage, extension) or not (e.g. roads, power, health), would also improve the 'investment-readiness' of small-scale producers.

\section{Policies on contract farming and supply chain relations}

There has been renewed interest in contract farming as a potential alternative to large-scale land acquisitions, allowing farmers to work their own land and leaving existing land rights intact. Contract farming is also promoted as a way for modern food manufacturers and retailers to include smallholders in their supply chains. At its best, contract farming may enable farmers to access more lucrative and more distant markets, reduce market risk, and increase income stability for farmers where the price of their produce is predetermined. It can contribute to smallholder empowerment and collective action. However, contract farming schemes bring small farmers into trading relationships with larger businesses. Without certain pre-conditions, contract farming can have damaging impacts, locking small producers into long-term relationships bearing an unequal burden of cost and risk for limited return, particularly where market concentration, unequal bargaining positions, or asymmetry of information allow powerful firms to offload risks onto smallholders and/or force down farm-gate prices. Smallholders may become dependent on a single firm or value chain, or investments may generate negative environmental and social impacts in the wider community (Vermeulen and Cotula, 2010). Critically, the ability to renegotiate, resolve disputes, or withdraw from a contract without unfair penalties is often limited by unequal power relations.

Moreover, as already noted in Section 1, women have tended to benefit less than men from contract farming schemes. Firstly, fewer women than men are contract farmers in their own right, due to women's poorer access to land and other productive resources (among other constraints). Thus, for example, a study of the fruit and vegetable sector in Kenya showed that fewer than 10 per cent of smallholder contracts were with women farmers, while a separate study of French bean contract farming schemes in Senegal showed that there were no femaleheaded households involved at all (Chan, 2010). The dominance of men as contract farmers in a range of crops is also borne out by evidence presented in the four country case study reports.

Secondly, wives of male contract farmers do much of the work, yet typically receive little of the income from crop sales and have little say in how that income is spent. For example, one study of sugar farming contracts in Africa found that women held less than half (43 per cent) of the contracts, yet provided the majority of the labour on 60-70 per cent of the contracted plots. A recent literature review found not only that this trend is widespread in African contract farming schemes, but that men frequently spend the income they earn from contract farming on personal rather than family needs (Chan, 2010). The Guatemala case study demonstrates that this is not just an African phenomenon: in Chichoy Alto village, women contribute a significant amount of labour to the cultivation of Chinese pea, including having primary responsibility for land preparation, planting, and harvesting, yet in 80 per cent of households involved in growing this crop, women receive only 20 per cent of the income (Guastar and Ozeta, 2011).

Thus, while women undoubtedly do benefit from contract farming in some cases, overall the evidence points to a trend of women bearing a substantial proportion of the (labour) costs, but reaping few of the benefits.

Producer organizations (POs) have in general not emerged as vehicles for small-scale producers to negotiate with agribusiness to improve the terms on which contracts are set and enforced. According to Pari Baumann, the function of most farmers' organizations that have emerged within contract farming schemes is about delivery of the contract, i.e. organizing and aggregating smallholder production (Baumann, 2000). The Guatemala study reports that the 
directors of POs in many cases become middlemen. The Philippines study reports that 'growership' contracts under co-operatives achieve a higher price per box for bananas due to the greater bargaining power of co-operatives relative to individual growers. However, once the co-operatives' management and tax fees are deducted, individual cultivation is seen to generate the highest annual income for the grower.

Contract farming is only one form of market relationship between small-scale producers and large companies. However, many of the same types of opportunity and challenge exist for other alternative approaches, including farmer-owned businesses, joint ventures, leases, and management contracts. In all cases, without attention to the legislative environment, and without active policy interventions in market governance, the promise of market-led development, business investment in agriculture, and 'pro-poor' value chains will be unfulfilled. ${ }^{91}$

Contract farming often does not need government intervention beyond the provision of key public goods, especially infrastructure and effective dispute resolution mechanisms. But in promoting equitable forms of contract farming, there is a useful public role - for government and NGOs - in ensuring that farmers' land rights are secure; that farmers have access to information on technology and markets; and that they are helped to negotiate a fair deal (Vermeulen and Cotula, 2010); as well as monitoring, supervision, or regulation of contracts, provision of model contracts, dispute resolution mechanisms, and even underwriting promising schemes, guaranteeing returns to investors and farmers (Wiggins et al., 2010). Breaking of contracts is very rarely challenged in court either by producers or their buyers, and the role of POs in collective enforcement of contracts is rarely used.

Governments may further encourage equitable contracting by facilitating contacts and providing information, including model contracts. Governments may choose to monitor, supervise, or regulate contracts. In the Philippines, the Department of Agrarian Reform and the Department of Agriculture provide extension services to contract oil palm growers, including monitoring of the implementation of contracts (Box 13).

\section{Box 13: Palm oil contracts with smallholders in Mindanao, Philippines}

In the Philippines, the palm oil industry is expanding rapidly, particularly in the island of Mindanao, where about a million hectares are potentially suitable for production. Currently, there are four large palm oil firms with milling plants in the country. These firms rent and own land as well as contract for their supply. Two types of arrangement or linkage between small-scale producers and large investors or buyers in the palm oil industry were studied contract growing and independent growing. Farmers engaged in contract growing for reasons of management support, market access, credit support, provision of inputs, and price protection.

The contract period is about 25-30 years, which is based on the lifespan of the oil palm tree. The quality of the produce and the pricing are specified in the proposal. Quality requirements determine the price of fresh fruit and any penalties imposed. A company technician is assigned to check regularly whether production protocols are being implemented properly. Flexible pricing is followed, which is adjusted based on global and local markets. Payment is made $25-30$ banking days after the delivery of produce. Contract growers are prioritized over independent growers during peak season.

In general, the linkage between producers and large investors is satisfactory. A majority (67 per cent) of the 87 farmers covered in the survey felt that they had a good relationship with the company they were dealing with. About one-third of them, however, had some concerns about delayed payments and high costs of inputs, which prompted them to sell to middlemen at a lower price even when they were still under contract.

Sources: Pajaro (2012); Philippines country study 
Policy in the Philippines includes a number of instruments aimed at creating opportunities for agrarian reform beneficiaries (ARBs), who represent the bulk of the small-scale producers in the rural sector, in contract growing and lease arrangements (individual lease and leaseback arrangements with co-operatives). These include, under the Department of Agrarian Reform, Administrative Order No. 9 of 2006 (DAO No. 9 of 2006), Reform Administrative Order No. 2 of 2008 (DAO No. 2 of 2008), and Republic Act (RA) No. 7652 of 1993, also known as the Investors' Lease Act.

In all cases, the intent of the policy is to support ARBs and ensure fair and beneficial treatment, but the details often mean that these same groups are discriminated against. For example, DAO No. 9 of 2006 promotes contract growing as the preferred agricultural venture agreement (which the majority of small-scale producers surveyed, both men and women, also said they preferred) over lease or leaseback arrangements, and promotes the opportunity for ARBs to become entrepreneurs through access to technology from investors or buyers and to credit through tripartite agreements with banks, buyers/investors, and agrarian reform co-operatives. However, a number of specific provisions within the policy mean that, in reality, leaseback rather than contract growing is the more favoured option. The Order also includes a mechanism to review and approve agricultural investment agreements, as well as to settle disputes to protect ARBs from unfair contract terms and to ensure that the terms are consistent with the guidelines it sets out.

An analysis of contracts is not complete without noting that infringement of contract terms occurs on both sides. For investors, side-selling by farmers is the main risk involved in contract farming and outgrower sourcing models; it is a major disincentive for companies to invest in smallholders, and means that they are reluctant to advance credit (pre-financing) or technology or to invest in technical upgrading. Buyers have expectations that technical investment comes with a degree of producer 'lock-in', so that smallholders do not take those skills to other buyers. But can this be done without trapping producers in inflexible business models? Farmers often prefer to sell their produce to middlemen for cash rather than wait - in the case of Guatemala for 45 days to obtain payment for exports, or to suffer a rejection of products by the agroexporter or a penalty of 5-10 per cent imposed by the importer abroad. Policy has actually been instigated to defend investor interests from side-selling. In the province of South Cotabato in the Philippines (where Dole Philippines' pineapple production and processing plant is located) an ordinance has been implemented which criminalizes side-selling, or 'pole-vaulting' as it is known locally.

There is a range of strategies to reduce the risk of side-selling, from buying 100 per cent of the harvest, including $B$ and $C$ grades; to not contracting exclusively for 100 per cent of production (e.g. in the Philippines); to 'progressive pricing' in which producer prices are adjusted according to a transparent formula. But these strategies have much more to do with private business models than with public policy.

Apart from 'growership' contracts in which smallholders supply agribusiness companies with produce from their land, there are also contracts in which smallholders lease their land and take employment on the estate or plantation. In the case of banana production in the Philippines, a critical pre-condition normally set by buyer exporter groups for land rental agreements is that the landowner or land reform recipient should have a clear title to the land offered. The rental period is typically for 15-20 years, and during this period the landowner or a member of the family is employed with the firm. 


\subsection{SUMMARY OF KEY FINDINGS, SECTION 3}

Policies regulating agricultural investment include diverse policy levers that favour both smalland large-scale farming. Contexts are different, and some national policy frameworks are more conducive than others to small farm development, or to the steps taken by some countries to restrict foreign land ownership. But overall, prevailing trends in policy favour large-scale land acquisitions over small farm development.

Policies on investment promotion and on the tenure regime applicable to land, water, and natural resources are critical in this respect. Many countries have enacted policies that, if properly implemented, would support investment by small-scale farmers and create incentives for models of corporate investment that include small-scale producers. Measures that strengthen local rights to land and natural resources, legal requirements for local consultation and FPIC, as encouraged by the CFS Guidelines, effective regulation of commercial investment, and targeted government action to promote the equitable inclusion of small-scale producers in value chains would all tend to promote more inclusive forms of investment in agriculture. But even where these policy measures are in place, shortcomings in implementation have often resulted in outcomes that fall below expectations. Effective governance requires not only well thought out policy design, but also sustained investment in policy implementation including capacity strengthening in government regulators and among the groups that would stand to gain from proper implementation, namely small-scale producers.

From a gender perspective, the most critical types of investment-related policy are those pertaining to land rights, water rights, and investment regulation. With regard to land rights, some countries still retain gender-discriminatory clauses in national land laws and policies, and clearly these need to be repealed. However, on the whole many national policies are now fairly progressive in terms of policy intent, and the key challenge is the implementation of these policies. To address this, the capacity and influence of 'national machineries' responsible for promoting gender equality objectives need to be strengthened. Equally, there is a need to address the conflicts that frequently arise between progressive statutory law, on the one hand, and customary land laws that perpetuate patriarchal land allocation practices on the other. With regard to investment regulation, the research for this report identified no policies at all that addressed gender issues. Thus, in addition to strengthening general investment regulation policies in terms of their overall ability to protect the interests of local people (men and women), explicit gender equality objectives and criteria need to be incorporated.

Some may argue that tightening the policy frameworks regulating investment in agriculture may constrain investment flows to countries that badly need them. For host countries, however, attracting investment is arguably not an end in itself, but a means to an end. The ultimate goal is improving local livelihoods, while respecting the environment - in other words, promoting inclusive sustainable development. This goal is reflected in the wording of some international treaties and also national laws that aim to promote commercial investment. For example, the preamble of Mozambique's Investment Act of 1993 refers to the role of private investment in promoting 'progress and the improvement of well-being in the country'. ${ }^{92}$ But if investment is only a means to an end, then not all investment is good. The quality of the investment - that is, its ability to pursue the stated policy goals - is critical. Quality is determined by the inclusiveness of the investment, not by corporate philanthropy at the fringes. Tightening policy frameworks may result in some economic opportunities being missed, but will also maximize the benefits of those opportunities that are seized. Quality investors may also welcome policy reforms that, in favouring more inclusive investment models, create a level playing field vis-à-vis their less scrupulous competitors. And as resources become scarcer and commodities more expensive, companies under pressure to assure themselves of a secure supply may become even more willing to strengthen their commitment to those communities in which the commodity is produced.

The policy levers that can influence agricultural investment either in support of agro-industrial development or in support of smallholders and women are summarized in Table 3. 
Table 3: Agricultural investment

\begin{tabular}{|c|c|c|c|c|}
\hline \multirow[t]{2}{*}{ Policy lever } & \multicolumn{3}{|l|}{ Policy intent } & \multirow{2}{*}{$\begin{array}{l}\text { Implementation } \\
\text { Issues }\end{array}$} \\
\hline & $\begin{array}{l}\text { Policies that } \\
\text { favour large- } \\
\text { scale agriculture }\end{array}$ & $\begin{array}{l}\text { Policies that support } \\
\text { smallholders }\end{array}$ & $\begin{array}{l}\text { Policies that } \\
\text { support women }\end{array}$ & \\
\hline $\begin{array}{l}\text { Investment } \\
\text { policies }\end{array}$ & $\begin{array}{l}\text { Minimum size } \\
\text { requirements } \\
\text { for the } \\
\text { application of } \\
\text { investment } \\
\text { codes } \\
\text { - Structure of tax } \\
\text { incentives }\end{array}$ & $\begin{array}{l}\text { Scrutiny of } \\
\text { investment } \\
\text { proposals and } \\
\text { monitoring of } \\
\text { approved } \\
\text { investments to } \\
\text { protect smallholder } \\
\text { interests } \\
\text { - Tax incentives for } \\
\text { sourcing from or } \\
\text { working with } \\
\text { smallholders }\end{array}$ & $\begin{array}{l}\text { - Gender- } \\
\text { sensitive } \\
\text { screening and } \\
\text { monitoring }\end{array}$ & \\
\hline $\begin{array}{l}\text { Control over } \\
\text { land and } \\
\text { natural } \\
\text { resources }\end{array}$ & $\begin{array}{l}\text { - State control } \\
\text { over resource } \\
\text { and power of } \\
\text { eminent } \\
\text { domain } \\
\text { - Weak local } \\
\text { rights, e.g. for } \\
\text { 'non- } \\
\text { productive' } \\
\text { land } \\
\text { - Preference for } \\
\text { individual over } \\
\text { collective } \\
\text { rights } \\
\text { - Weak } \\
\text { enforcement } \\
\text { mechanisms } \\
\text { under } \\
\text { international } \\
\text { human rights } \\
\text { law }\end{array}$ & $\begin{array}{l}\text { - Measures that } \\
\text { strengthen local } \\
\text { rights to land and } \\
\text { natural resources } \\
\text { - } \text { Redistributive } \\
\text { reforms } \\
\text { - Protection of } \\
\text { customary rights } \\
\text { - Simple, low-cost, } \\
\text { accessible land } \\
\text { records/ } \\
\text { registration } \\
\text { - Requirements for } \\
\text { local consultation } \\
\text { and FPIC }\end{array}$ & $\begin{array}{l}\text { - Repeal of } \\
\text { gender- } \\
\text { discriminatory } \\
\text { clauses } \\
\text { - Address } \\
\text { conflict } \\
\text { between } \\
\text { statutory and } \\
\text { customary } \\
\text { land laws } \\
\text { - Guarantees } \\
\text { for women to } \\
\text { own, inherit, } \\
\text { buy/sell land } \\
\text { in their own } \\
\text { right } \\
\text { - Joint land } \\
\text { titling } \\
\text { - Gender } \\
\text { quotas }\end{array}$ & 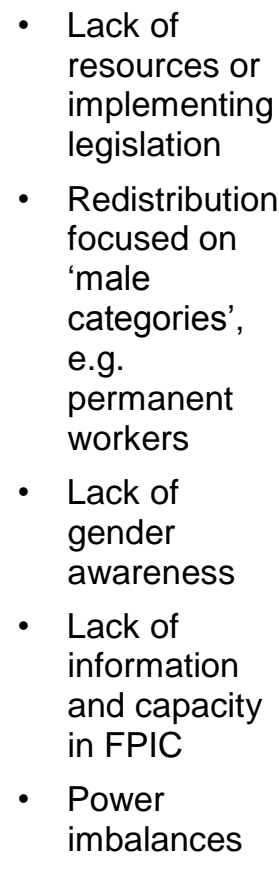 \\
\hline $\begin{array}{l}\text { Conditions } \\
\text { for investor } \\
\text { access to } \\
\text { land and } \\
\text { natural } \\
\text { resources }\end{array}$ & $\begin{array}{l}\text { - Low or no fees } \\
\text { for rights }\end{array}$ & $\begin{array}{l}\text { - Regulation of } \\
\text { commercial } \\
\text { investment } \\
\text { - Restrictions on } \\
\text { land ownership } \\
\text { - Charging adequate } \\
\text { prices for land }\end{array}$ & & \\
\hline $\begin{array}{l}\text { Contract } \\
\text { farming and } \\
\text { supply chain } \\
\text { relationships }\end{array}$ & & $\begin{array}{l}\text { - Access to } \\
\text { information on } \\
\text { technology and } \\
\text { markets } \\
\text { - Contract support, } \\
\text { regulation, } \\
\text { monitoring } \\
\text { - Dispute resolution } \\
\text { mechanisms }\end{array}$ & & \\
\hline
\end{tabular}




\section{POLICIES FOR INCLUSIVE MARKET GOVERNANCE}

Following on from analysis of policies that influence commercial investments in agricultural production, this section looks at the governance of markets in favour of or against smallholder production. By 'governance', this report means the determinants of the terms on which actors participate in a market. Governance for inclusive market development balances risk and reward between market actors, especially women and men in small-scale agriculture and the rest of the market, and thereby allows small-scale farming and women in smallholder agriculture to flourish.

Poor market governance manifests itself in exclusion or unfairness in the direct market linkages between investors and smallholders. This was covered from a policy perspective in section 3.3 above. Indeed, much policy attention to supporting smallholders in an era of heightened commercial investment in agriculture has focused on improving the inclusiveness and fairness of trade between investors and smallholders, often as outgrowers in contract farming schemes, across large imbalances of market power. The prescriptions are generally for inclusive business models, increased producer organization, and fairness in contracts.

But market governance is not all about small producers trading with big companies. Many of the policy levers that make markets work better for small-scale producers do not have much in common with the needs of investors or the demands of modern value chains. A wider understanding of the levers of market governance encompasses the performance of agricultural markets as a whole, rather than individual value chains. Rather than 'inclusion' being defined as bringing small-scale producers into the supply chain of an individual company, it is about the diversity of markets working for the majority of small-scale producers across a sector. In fact, the trend of privileging a value chain approach to smallholder development in markets can lead to a fragmented enabling environment for smallholders. Furthermore, value chain interventions are more likely to involve only the top 2-10 per cent of small-scale producers, and in terms of spend per farmer may well be un-replicable by governments and thus not sustainable in the longer term (Hellin et al., 2009).

The majority of smallholders, in most cases, are not formally organized in the market (as cooperatives or other forms of economic organization), and trade with the informal sector. These are markets of the poor that may link small-scale producers with low-income urban citizens, via informal institutions that are often distant from public policy and big business. And, as Robbins (2011) states, 'the majority of trades in a wide range of commodities ... will continue for the foreseeable future to be made deep in the countryside, and the market conditions that result in the deals are the only ones of relevance to small-scale producers and traders.' Here local traders can take advantage of the need for cash of small producers living in poverty, as without the ability to aggregate or store or process their product, they are price-takers. Poor enforcement on seed and other input supplies frequently results in crop or yield failure, compounded by limited R\&D or delivery of technology transfer through producer networks.

Under these circumstances, when the state has withdrawn from regulating the broad range of markets, together with low investment in infrastructure and services, and when small-scale producers are directly exposed to global market forces, smallholders experience poor market governance in a number of ways:

- High market volatility, competition from cheap imports, and arbitrary use of trade measures (see Box 14);

- Lack of access to government programmes or subsidized inputs (see Box 15); 
- Markets distorted by cartels, monopolies, and high degrees of concentration - for example, the concentration ratio in the Philippines agri-food sector is the highest in Asia, and the market share of the top four firms can be as high as 90 per cent (see Box 16);

- Major disincentives, including taxation, to organize production or to trade with the formal market;

- Criminality and rent seeking from officials at roads, borders, and marketplaces;

- Limited market options, with limited ability to delay for the right sale or to identify more profitable markets.

\section{Box 14: Consumer vs producer interests in the face of price spikes}

Under liberal trade regimes, increased urban spending power can suck in cheap imports rather than drive agricultural growth domestically. This conclusion is supported by data from intensive empirical research under the AFRINT study which researched the drivers of agricultural intensification in nine sub-Saharan countries; the authors note that in the latter half of the 1990s cheap imports may have undermined domestic production. Under trade agreements, there is usually considerable space to allow a government to use border measures (especially higher tariffs) to protect the domestic market in developmentally sensitive areas, to support rural livelihoods and food security. However, the use of border measures is usually implemented to maintain domestic food prices in favour of consumers rather than producers.

Faced with high food prices, in 2008 all four focus countries studied for this report removed tariffs or duties on the import of food staples: Tanzania removed import duty on cereals and introduced a ban on maize exports; Nigeria drastically reduced the import tax on rice (from 100 per cent to 2.7 per cent) and allocated a special fund for rice imports; Guatemala cancelled import taxes on wheat flour and eliminated tariffs on powdered milk, yellow corn, eggs, maize flour, vegetable oil, chicken, rice, and fertilizers; and the Philippines government removed quotas on imports of rice and maize and replaced import tariffs on rice, which had been designed to encourage local production, with a less substantial import service fee.

Export bans are another way of intervening in the market to manage domestic prices. According to the Tanzania study, export bans decreed by the Prime Minister for grains, as happened in 2011-12, affect smallholder farmers, as the bans are announced when farmers have harvested the crop and prices are higher in neighbouring countries. The whole commodity chain for a particular crop loses out, to the detriment of long-term food security.

High food prices can also drive rural dislocation, especially in Rural World 3. In Guatemala, according to a study of volatility in food prices, rising prices, especially of food, drive rural migration to urban areas in search of employment, leaving smallholdings in the hands of women or, in the worst case, abandoned.

Sources: Djurfeldt et al. (2000); FAO (2010); Oxfam International - IDS; 93 and country studies. 
Box 15: Poor targeting of subsidies and incentives

In Nigeria, a respondent in the Federal Capital Territory working with women farmers reported that, 'Until recently, ministries have not had records of farmers, so proper targeting of incentives has been difficult. Incentives have gone to unintended beneficiaries, sometimes with the connivance of project implementers. Besides, the government has records of large farmers and they can easily be contacted and invited for deliberations on agricultural policies, unlike smallholders.' Nigeria's Growth Enhancement Support (GES) policies, which commenced in 2011, included a shift from a flat fertilizer price subsidy to targeted support for small-scale farmers, through involving banks and telecoms companies to deliver support to registered farmers, and by paying 50 per cent of the cost of fertilizer, seeds, and agrochemicals directly.

Source: Nigeria country study.

\section{Box 16: Cartels and monopolies}

In most developing countries, it is cartels of dominant and politically connected firms and interest groups in more traditional wholesale and commodity markets that present the greatest threats to open and competitive markets. Cartels in markets for inputs and the processing of food staples, as well as control of wholesale markets, can reinforce the poverty of both producers and consumers. Brokers and traders may control access to wholesale markets, which prevents farmers from trading directly; this was reported for onion markets in Tanzania in one detailed study (Koenig et al., 2008). Cartels may be state-sanctioned, as with the Agricultural Produce Marketing Committee (AMPC) Act in India, which controls the supply of marketing services and infrastructure in market yards (mandis), with all the drawbacks and inefficiency associated with a monopoly.

Examples of anti-competitive practices in sub-Saharan and South Asia cited by Khemani (2007) that can affect the welfare of farmers (as well as low-income consumers) include the following:

- Malawi - cotton trading: There are very few buying companies, and they collude to exploit in the terms and prices offered to cotton growers;

- Ethiopia - fertilizers, seed: Alleged domestic and import cartels formed by 'partystatals' (firms owned mainly by the political party in power), with market-sharing agreements covering different farming regions, have exploited farmers and increased costs for them and the price of products;

- Bangladesh - staple foods (rice, potatoes) and sugar: Widespread allegations of uniform prices/cartels;

- India - staple products: Cartelization of the supply of sugar, food grains, and vegetable cooking oil.

Poor market governance is also experienced by agribusiness investors, through unreliable supplies, side-selling, and poor-quality produce. 


\subsection{WHAT ARE THE POLICY LEVERS TO SHAPE MARKETS?}

The policy levers of market governance for wider inclusiveness relate to supporting:

- Stronger organization and market power of small-scale producers;

- Greater diversity of market outlets;

- Improved price stability and producer share of market value;

- Market preferences for small- and family-scale producers;

- Space for small farmer development within trade and investment agreements.

These policy levers are summarized below.

\section{Policy support for producer organization: incentives for POs in the market}

Producer organizations are seen as a key way for producers to engage in markets. They offer potential for economies of scale, reduce transaction costs, reduce risk in financial transactions, and give voice to producers in the policy process. Due to the logistical challenges of working with a large number of individual smallholders, investors often prefer to engage with organized groups of smallholders. Thus, many companies choose to procure from pre-existing, formally registered producer co-operatives or other formal POs, including those initiated by private actors in the supply chain.

There has been a resurgence of interest in POs. Public policy has a big role to play in overcoming the documented or perceived shortcomings that POs may have relative to individual trade - such as poor governance, poor competitiveness in collective marketing, low levels of capitalization, political interference, disconnection from the membership, and barriers to women members. These limitations explain why the majority of producers in developing countries are not formally organized in the market - for example, only 10 per cent of small-scale farmers in Guatemala are organized in co-operatives and the figures for horticulture in Honduras and $\mathrm{El}$ Salvador are even lower (Hellin et al., 2009). They can also explain why some outgrower and contract farming schemes prefer individual contracts over trade with co-operatives and other producer groups.

Women farmers face particular constraints to joining co-operatives and POs, and in most developing countries female membership numbers lag considerably behind those of male membership. For example, in Ethiopia, only 2 per cent of women - as opposed to 13 per cent of men - are members of agricultural co-operatives (Chan, 2010). One of the key barriers to entry for women is the enforcement of inappropriate membership eligibility criteria. For example, many co-operatives require that members must own the land that they farm, a stipulation that excludes most rural women due to their weak land rights. Other groups will allow only one member of a household to become a co-operative member, which in effect limits membership to the male head of household and prevents married women from joining in their own right. Some groups also stipulate minimum production or harvest volumes, a requirement that many women may not be able to meet due to their poorer access to land and other productive resources compared with men (Chan, 2010).

In addition to inappropriate membership criteria, lower education and literacy levels can also discourage women from joining formal organizations or make it difficult for them to participate in group activities; likewise, domestic responsibilities and cultural barriers often prevent women 
from attending group meetings (Baden and Pionetti, 2011). Even where women are relatively well represented in the general membership of co-operatives, they tend to be poorly represented in their governance structures. In Kenya, for example, while women represent nearly a third (29 per cent) of overall membership, they comprise only 9 per cent of the management of agricultural co-operatives (Chan, 2010); and in Guatemala, while women make up nearly half (48 per cent) of co-operative membership, they are poorly represented in the leadership of Federural, the federation of co-operatives (only one of the five leaders is a woman). ${ }^{94}$ Key contributing factors to women's poor representation in governance are cultural beliefs (which perceive women to be unsuitable for leadership positions), women's lower education levels (since literacy and higher educational qualifications are often considered as prerequisites for becoming a co-operative board member), and women's greater burden of household responsibilities (which means that most women struggle to find time to attend committee meetings and to meet other responsibilities of office) (Chan, 2010). Thus, cooperatives often fail to act in the interests of their female membership, even if women comprise a significant part of the membership.

In general, there is a lack of rigorous and detailed investigation into the role of public policy in improving the social and economic performance of POs, with the majority of research papers looking at incentives for producer organization. However, there are some interesting research projects, particularly in the co-operative literature, and particular note must be made of the Cooperative Law and Regulation Initiative (CLARITY) project. ${ }^{95}$

The key policy levers in improving the position of POs in the market can be divided into a number of themes, as follows.

\section{Company and co-operative law}

This section addresses laws governing the establishment, registration, and operation of cooperatives, including those operating in the agricultural sector. Definitions of co-operatives, producer organizations, and producer companies are important, as they detail the governance structure, influence the organization's ability to raise finance, and define members' voting rights. Formalizing what a co-operative, a producer organization, a producer company, or a producer association looks like in law not only legitimizes the form itself, but also gives policy space for incentives to be offered.

There are important policy questions about 'traditional' co-operatives operating along International Co-operative Alliance (ICA) principles ${ }^{96}$ and the emergence of new hybrid models (Penrose-Buckley, 2007), particularly about which model(s) public policy should be defining and making space for, including the capacity to act on a commercial basis. 'New Generation Cooperatives', with closed membership, limited numbers of members, and profits and voting rights distributed according to members' share of the business, may improve commercial performance, but for non-members they may seem indistinguishable from private agribusinesses.

In China, where the rural economy is still made up of millions of small farmers and traders, a law on farmer professional co-operatives (FPCs) came into force in July 2007. It grants a clear legal status to FPCs 'as independent, voluntary and democratically administered organisations, which are registered under the State Administration for Industry and Commerce (SAIC) ${ }^{\prime}{ }^{97}$ Registration of co-operatives has grown at a considerable rate in China since the law, but coops are as yet present in only a small share of China's villages (Huang et al, 2012).

In India, the Companies Act (1956) was amended in 2002 to establish Primary Producer Companies (PPCs), to 'retain the desirable basic structure of cooperatives while at the same time enabling the primary producers to have the flexibility, freedom and efficiency of a private limited company' (NRAA, 2009: 4). Since then, growth in producer companies has been steady (but not dramatic). Like traditional co-operatives, PPCs face an institutional problem in their ability to raise working capital and credit. The NRAA paper asks for better treatment of PPCs in 
public policy to (a) put them on an equal footing with limited companies and allow them access to credit; and (b) allow them similar enabling provisions as co-operatives, perhaps extended to tax exemptions for the initial set-up period. The Indian government has also introduced a proposal for a new law which would improve access to finance for PPCs by enabling the National Cooperative Development Corporation (NCDC) to make loans to them directly. ${ }^{98}$

In South Africa, there has been resistance from the traditional co-operative movement to a draft bill which was to allow non-member investors into co-operatives as a way to get around the institutional problem of failing to raise enough working capital (Nganwa et al, 2010).

In Malawi, owing to overt government involvement in co-operatives (by law), the National Smallholder Farmers' Association of Malawi (NASFAM) chose to register as an association. But as one study points out, registering as an association has its drawbacks too; the structure is not really designed for business activities, and in many countries associations are treated as nonprofit organizations. To get around this, NASFAM has created a separate private company (Penrose-Buckley, 2007).

The autonomy of POs is repeatedly emphasized throughout the literature, particularly regarding co-operatives, owing to their frequent historical experience of becoming an extension of the state. There are numerous examples of state involvement in co-operatives. As such, best practice in co-operative law (e.g. ICA, CLARITY, International Labour Organization (ILO)) has at its heart the autonomy of co-operatives, particularly from state involvement, but also from others including financial institutions and non-member investors.

POs can be a way towards social development, and many governments and donors recognize this, so the natural inclination is to want to support and promote this role. But there is some push-back from the co-operative movement about the types of support given. As noted in the 'World Development Report' (2008), the challenge 'for governments and donors is how to assist without undermining the organisation's autonomy' (World Bank, 2008: 154). This has important implications for the types of incentive that should be offered to POs, particularly in light of the strong support for the principle of equal treatment advocated by the co-operative movement.

Government support structures for co-operatives, as well as co-operative laws, also carry important gender implications. Even laws and policies that are generally supportive of effective smallholder organization can have negative implications for women farmers. This is because, as noted above, while few co-operative laws directly discriminate against women, some include clauses that in effect exclude most female producers from becoming members and prevent female members from being elected to governance structures. Thus, certain co-operative laws give legal backing to the types of internal membership rule noted above (e.g. land ownership requirements) that contribute to the exclusion of women members (International Cooperative Alliance, 2010; FAO, 2007b).

On the positive side, some countries have introduced explicit anti-discrimination clauses into cooperative law. For example, the 1991 Cooperative Societies Act of Tanzania, as amended by the Cooperative Societies (Amendment) Act of 1997, explicitly prohibits gender discrimination in access to membership, states that both women and men can be elected as co-operative representatives, and affirms the principle of equality of all members in the activities of cooperatives (FAO, 2007b).

Nevertheless, given that it is the persistence of patriarchal socio-cultural attitudes and practices, combined with inappropriate internal rules of individual co-operatives which are the main contributing factors to persistent gender inequalities within co-operatives (rather than legal barriers), anti-discriminatory policy statements are rarely effective on their own. Some governments have recognized the need for affirmative action to increase women's participation in co-operatives, and have introduced such measures in co-operative law or related policy. For example, Namibia's Cooperatives Act of 1996 provides for women's representation in managing boards of co-operatives that have a minimum number of women members (FAO, 2007b) and 
Ethiopia's Plan for Accelerated and Sustained Development (PASDEP) pledged to raise the number of women participants in co-operatives from 13 per cent to 30 per cent (Baden and Pionetti, 2011).

A further potential policy area to encourage women's participation in, and benefits from, collective action is the provision of support for informal producer groups. Due to the barriers to entry to formal producer groups (including formal co-operatives) outlined above, the majority of women involved in collective action participate in informal rather than formal groups. Thus, if women are to benefit from government efforts to promote collective action in agricultural production and marketing more generally, relevant policies and their implementation need to ensure that informal as well as formal groups can benefit from incentives and other support measures provided. This applies not only to informal groups engaging in production, but also to informal labour sharing/pooling groups that help many poor women reduce their labour burden and free up more time for agricultural production and marketing activities. Labour-sharing groups have to date been completely ignored by policy initiatives (Baden and Pionetti, 2011).

\section{How to tax producer organizations - incentives and disincentives to organization}

The general consensus is that POs should be taxed on similar lines to companies. Best practice is recognizing the difference between transactions within a co-operative (not income, so should not be taxed) versus transactions between members and non-members (income-earning, so should be taxed). There is a history of policy makers misunderstanding the nature of cooperatives, and see the act of supplying produce to the co-op as an economic transaction rather than a means to generate enough produce to supply the market. Nyang et al. (2010) surveyed umbrella organizations for POs in Eastern Africa. While all of them believed that the policy environment was generally supportive, three of the organizations mentioned that double or even triple taxation by government at various levels was a serious barrier to PO development.

The Junta Nacional del Café (JNC) in Peru had to commit heavy resources to maintaining this principle of no taxation of intra-co-operative trade in shaping the new Cooperative Law. The law originally planned to tax internal transactions between members and the organization, which threatened to bankrupt a number of coffee co-operatives. However, advocacy work has meant that this plan has been overturned. ${ }^{99}$

Tax is often a barrier to formalization of POs in the market. For example, in the state of Maharastra in India, there has been growth in informal groups outside of traditional co-ops. Producers hesitate to become co-operative trading houses as they would then have to pay income tax. ${ }^{100}$

On the question of offering incentives to co-operatives, the ILO is quite forceful on the matter in asserting that co-operatives should not receive special treatment. When talking about historical state involvement in co-operatives, an ILO paper describes incentives as follows: 'Cooperatives were granted tax privileges, they had easy access to credit or state controlled support. In so far as these privileges violate the equal treatment principle or are granted because of the mere sake of the cooperatives being cooperatives, these privileges should not be granted anymore' (Develtere et al., 2008).

Examples of tax incentives for co-operatives include the following (Cooperatives Council of Australia, (1998):

- China: transactions of agricultural products and inputs between farmers and farmer professional co-operatives are free of VAT and stamp tax.

- Indonesia: Tax relief is applied only on transactions between co-operatives and their members.

- Malaysia: Co-operatives receive income tax exemption for the first five years. 
- Philippines: Member-only transactions are exempt. Transactions between members and non-members are taxed, but only if income is greater than PHP $10 \mathrm{~m}$, and only ten years after registration.

- Guatemala: Income tax law exempts the transactions of formal agricultural co-operatives with partners or with other co-operatives, with other earnings subject to income tax (though it also limits co-operatives' capacity to claim back VAT breaks on exports).

Where POs are not effective in aggregation and trading, government support for the formation of specialized intermediaries can fill the 'missing middle' between small-scale producers and markets. The Oxfam GB Enterprise Development Programme (EDP) has invested in 17 producer-owned intermediary organizations. These specialized intermediaries allow small-scale producers to connect with modern markets by offering aggregation combined with professional production, financial, and marketing management. Secondly, they increase market options, thus reducing producers' market risk and increasing their ability to identify profitable markets. So far, on average each intermediary has increased its producer base from 1,300 to 1,700 small producers, has increased the proportion of women members from 21 per cent to 37 per cent, and has increased the profits of these intermediaries by 50 per cent. The programme has highlighted the need for appropriate finance, mentoring, and business services for producer-led (and often female-led) enterprises connecting remote producers to modern markets.

\section{Maintaining a diversity of market outlets}

Because small-scale farmers sell predominantly into traditional wholesale and informal markets, and will struggle to find a place in modern chains dominated by supermarkets, an important area of public investment is in maintaining a diversity of market outlets - from street vendors to local wet markets to national wholesale markets and terminal markets - as a public good. ${ }^{101}$ The appropriate investment can help traditional markets to evolve and compete with the modern sector. This is an extension of investment in infrastructure (Section 2.2) but is worthy of more indepth analysis. It is also linked to policy attitudes to the informal sector, for which wholesale markets can be very important; states and municipalities can either declare war on informality, as untidy, un-modern, unhygienic, and tax-avoiding, or work with it, especially to improve food safety, through a process of inclusive formalization.

To talk about wholesale markets in the 21 st century, it is essential to understand the massive changes in retailing that have occurred in the past 50 years, and the rise of the supermarkets and restructuring of the wholesale sector. This has been summarized by Reardon et al. (2009), who observe a new emerging literature on restructuring of the wholesale sector, pointing to nascent consolidation and specialization in all areas of wholesale markets.

There might be a temptation to see this latest phase of market restructuring, and the growing dominance of supermarket chains that procure directly from large farmers, as spelling the end for wholesale markets. In Latin American countries, Berdegué and Fuentealba (2011) suggest that this is indeed the case. However, this shift is not complete and many forces still exist that support the survival of traditional retailing, while the wholesale sector that supports it will persist in many places. ${ }^{102}$ Haggblade (2011) describes this scenario in Africa and how it is essential for the public sector to support wholesale markets because they supply the traditional outdoor wet markets that continue to dominate urban retailing, even in large urban centres such as Nairobi. Citing the work of Abbot and Tschirley, Haggblade concludes:
IIn these cases, traditional wholesale markets typically continue to distribute the bulk of marketed fresh produce to urban retailers. But they quickly outgrow their physical infrastructure in the face of rapidly growing urban market demand. Although traditional horticultural wholesale markets remain accessible to smallholder farmers, many require significant support in coping with the rapidly expanding scale of market activity and consequent problems of market organization, food perishability, sanitation and traffic congestion. In most cases where traditional wholesale markets remain the primary 
market assembly points, public support becomes necessary to finance investments in upgraded wholesale market infrastructure, update city planning, zoning and sanitation systems and improve market management in order to ensure the equity and efficiency of growing fresh produce supply systems.'

The fact that 'private investment in modern integrated supply chains cannot be relied upon to solve the multitude of problems that increasingly plague these traditional production and marketing systems' has profound policy implications (Tschirley et al., 2010).

There are many reasons to support the wholesale sector, not least because it provides a diversity of outlets and facilitates the inclusion of smallholders in markets, therefore having a potentially positive developmental impact. Traditional markets can be a bridge for small-scale farmers to increase their capacity and eventually to link to modern markets (Vorley et al., 2009).

There is not much written on actual examples of current public sector support for wholesale markets, particularly in order to maintain a diversity of market channels for small-scale producers. The analysis divides broadly into three sets of levers, which: a) give the private sector space through the public sector withdrawing from market oversight i.e. more liberalization; b) support wholesale markets in terms of investment through PPPs; and c) protect wholesale and traditional retail from competition from modern retail systems. Some examples are detailed below.

\section{Freeing up competition}

Government involvement in wholesale markets is prevalent, such as in India through the ACMP Act, which seems to favour the middlemen (commission agents) in wholesale markets. In discussing the general state of the horticultural sector in sub-Saharan Africa, Tschirley et al. (2010: 14-15) briefly summarize the substantial but mostly indirect effects of government policy on the sector as follows:

- Legal frameworks for establishment and management of markets that often hinder active private sector engagement and contribute to the progressive decline of public marketplaces;

- Neglect of grades and standards that could raise quality over time and improve price predictability for farmers;

- Weak chemical regulations that allow internationally banned chemicals to be used by farmers, who are frequently unaware of their negative environmental or health effects; and

- Cumbersome procedures for the formalization of businesses, which contribute to the propagation of numerous small-scale informal food trading businesses.

However, several papers have cited the roll-back of government oversight of wholesale markets (Warner and Kahan, 2008; Vorley et al., 2008). In India, some states have amended their regulatory frameworks. Deregulation can enable participation of the private sector and cooperatives in the construction and operation of wholesale markets, and allows farmers to sell vegetables and fruits directly to the market or to a private company.

\section{Providing direct investment and support}

Tschirley et al. (2010) write of an accumulated hard infrastructure deficit in African horticultural marketing, and argue that the private sector needs to be actively engaged in overcoming this. Apart from the traditional sources of private capital, such as banks and financial institutions, traders and merchants can also be considered as sources of capital for facilities that they will directly use (such as stands and storage facilities). Government may need to make only ancillary contributions, e.g. through making publicly owned land available or undertaking related improvements in road access (Seidler, 2001). Decentralization has expanded the provision of local market infrastructure in many countries. More often, the approach will be in the form of PPPs, as proposed for new wholesale markets in Nairobi and Kigali. ${ }^{103}$ But for 'partnerships' to live up to their name, modifications to existing legal frameworks and accompanying attitudes will 
often be required. Simple methods of improving market systems for agricultural goods in local markets, such as the establishment of fixed marketplaces and the introduction of calibrated weighing scales, can be carried out at low cost and with local resources (Robbins, 2011).

\section{Box 17: The Iringa region main market in Tanzania}

Tanzania's National Strategy for Growth and Reduction of Poverty 2010-2015 (MKUKUTA II) includes a strategy for strengthening physical infrastructure to support the growth of employment-generating and profitable agriculture, including physical market infrastructure. The quality of most market infrastructure in Tanzania is poor. The main market for the Iringa region, in Iringa town, stands out as an exception, in the context of ensuring that smallholder farmers' produce reaches end users. The market building, where agricultural produce is sold both retail and wholesale, was renovated in 2011 through a PPP between Iringa Municipal Council (IMC) and the market traders. The traders agreed to contribute 100 per cent of the cost of doing this, on agreement that they will operate in the market for a given number of years without paying rent. The market is governed by a board constituting the IMC administration and traders. It is operated by a private company, which is responsible for opening and closing times, security, revenue collection, and sanitation. Bylaws on the governance and operation of the market exist and are enforced.

Source: Tanzania country study

Rather than being a supplier to traditional retail markets, some significant public investments have been made to support a role for wholesale as an intermediary between small-scale farmers and the modern retail sector, facilitating linkages between the two. Shepherd gives examples of Thailand, where the Bureau of Agricultural Economics has opened a supply chain unit and a government-sponsored distribution centre for local retailers, and the Federal Agricultural Marketing Authority in Malaysia, which has had an active programme of promoting farmer-supermarket linkages and is also working to improve distribution channels for produce (Shepherd, 2005: 15).

These public investments to support market linkages between small-scale farmers and modern food chains have not always been successful. In the case of Swaziland, a large investment in wholesale markets by the government and the International Fund for Agricultural Development (IFAD) in the 1980s/1990s had only a limited impact on smallholders, who instead preferred to sell their produce off the field for cash. In fact, government efforts effectively created a subsidized wholesale market that benefited imports of fruit and vegetables. ${ }^{104}$ There was a similar experience in Kenya with Japanese-funded Horticultural Crops Development Authority (HCDA) procurement hubs for the horticulture cold chain, which were bypassed by smallholders and traders, who continued to use their informal networks. ${ }^{105}$

\section{Protecting wholesale and traditional retail from competition with modern retail}

Governments may legislate to protect wholesale and traditional retail from competition from modern retail. The emphasis has been on protecting the smaller retailers and traders first, with knock-on effects for their suppliers, comprising:

- Zoning restrictions: These are primarily aimed at protecting local retailers and small traders, but can also affect their suppliers indirectly. In Southeast Asia, Indonesia has imposed zoning restrictions on supermarkets larger than 200 sq metres, which must be located at least 500 metres from traditional markets, while Thailand prohibits retail stores larger than 1,000 sq metres within $15 \mathrm{~km}$ of commercial town centres. In Viet Nam, small retailers have exerted considerable political pressure due to fears of further liberalization of retail FDI.

- Restrictions on retail FDI: FDI in Indian retail had been limited to the wholesale and cashand-carry sectors in order to protect the multitude of small neighbourhood kirana stores, and 
also allegedly to protect small farmers. This regulation was repealed in September 2012, and an amendment is currently being debated. If passed, it will allow 51 per cent foreign investment in retail, although the ultimate decision will lie with state governments. An example given by Shepherd (2005: 13) is of Malaysia, 'where foreign investment in distributive trades is subject to approval of the Committee on Wholesale and Retail Trade, with the aim of encouraging the "fair and orderly development of the industry"'.

- Local content regulation that requires the purchase or use by processors or retailers of products of domestic origin.

While noting that diversity is key for smallholders' access to markets, that very diversity may have a negative impact on smallholder loyalty in contract farming arrangements. A lack of alternative markets can more tightly 'lock in' smallholders to contractual relationships. A comparative survey of oil palm investments in Indonesia and Cameroon noted that one reason why Cameroonian investments performed less well was because there is a local market for palm oil, giving rise to more side-selling. In other words, the 'leakage' of product to the local market undermined an investment based on small-scale producers rather than on large-scale plantations selling to mills. ${ }^{106}$ The overall implication is that healthy competition between domestic informal markets and modern contract farming for farm produce should improve the governance of both types of market.

\section{The importance of market diversity from a gender perspective}

Policies to maintain market diversity are also important from a gender perspective. Female smallscale farmers face particular barriers to entry into formal markets, and so rely even more heavily than men on informal markets to sell their agricultural produce (World Bank et al., 2009). This is because women, compared with men, have poorer access to land and other assets, agricultural inputs, technical knowledge, market information, finance, and time. As a result, they tend to produce smaller quantities than men, and may also be less able to consistently meet specified quality standards. Moreover, given that women often have primary responsibility for providing food for the family, they are often able to sell only a small proportion of their total output for cash. Thus, since formal traders/buyers typically demand larger volumes and higher quality standards, women are usually excluded from formal market outlets. A further constraint faced by women is that of limited mobility (a result of both cultural constraints and women's household responsibilities). As a result, women are often restricted to street vending, selling directly in local markets, or relying on traders to come to them (Baden and Pionetti, 2011; World Bank et al., 2009).

Thus, government policies that are hostile to informal markets are likely to have a negative impact on small-scale women farmers. Conversely, policies that seek to strengthen informal markets, in particular local markets, street vending, and wet markets, can contribute significantly to maintaining or improving market access for women producers. However, in many cases it is also important to have in place policies that are targeted at addressing women's specific market access constraints; otherwise, women may not benefit or may benefit less than men. This applies to transport infrastructure, as well as to infrastructure improvements at the marketplace. For example, in India, improvements in basic sanitation facilities, including toilets and drinking water provision at marketplaces - facilities of particular concern for women - were found to have helped increase market participation by women traders by 18 per cent. Other specific measures that have been shown to help increase women's market access are the allocation of reserved shops/areas for women traders in wholesale markets and the promotion of women's membership in market vendor associations (World Bank et al. (2009).

\section{Market co-ordination for improved price stability and producer share of value}

For small farmers to invest in production, price stability is key; low and volatile prices deter farmers from investing in higher quantities and quality of production. The market liberalization imposed in the late 1980 s and early 1990 s swept away parastatal marketing boards, ${ }^{107}$ which 
were felt to be cumbersome, inefficient, riddled with corruption, and poorly managed (Robbins, 2011), with the notable exception of Ghana's Cocoa Board. These reforms handed marketing functions back to the private sector, though without the ancillary investments promised to achieve market price transparency, competition in trading, and producer organization in the market (Robbins, 2011).

There is now, however, renewed interest in state intervention in markets, as the winds of liberalization have failed to usher in a new age of agricultural prosperity and food security and there is a general realization that the private sector has not filled the gap of co-ordinating markets. ${ }^{108}$ Effective market regulation can allow greater risk-taking, particularly by women and small-scale producers, and can also reduce the impact of remoteness from markets, thus ensuring greater resilience for relatively vulnerable small-scale producers. Some donors and governments are turning their eyes back towards such state involvement (albeit in a limited manner), especially commodity exchanges but also futures contract commodity exchanges, to help improve productivity and food security by co-ordinating markets and managing producer risk through:

- Facilitating competitive and efficient trade in agricultural commodities;

- Providing reliable and timely marketing information and intelligence;

- Providing transparent and competitive market price discovery mechanism and applying information and communication technologies (ICTs) to facilitate trade information access and use.

Peter Robbins (2011) reviewed five commodity exchanges that were set up with a very similar blueprint of local depots using a warehouse receipts system, linked to large warehouses at district level, and a commodity exchange at the apex, in Zambia, Kenya, Uganda, Malawi, and Ethiopia. The report suggests that a major problem of sustainability of funding for commodity exchanges exists, and that in the cases of Kenya and Malawi the exchanges have achieved so few of their original goals that they are not more than 'rudimentary market information services' (Robbins, 2011: 5-6). It is also important to note that the heavy regulation of certain commodities in Kenya (e.g. coffee and tea) affects the ability of the exchange to work in the marketing of these crops (UNCTAD/SFOA, 2006).

With the exception of Ethiopia, Robbins concludes that too much focus has been placed on the commodity exchange as a donor-driven 'silver bullet' intervention, with little or no time spent on addressing other market failures, especially agricultural extension services, market information services, producer organization, and storage and packaging facilities. 'It seems likely that so much faith was invested in the new top-down, commodity exchange-based system to deliver country-wide reforms, that funding for the nuts and bolts of a basic agricultural market system has been crowded out' (Robbins, 2011: 5-6). This supports the assertion of Rashid et al. (2010) who, after reviewing the purpose and potential of commodity exchanges in Africa, concluded that such exchanges might not be most suitable for reducing risk and transaction costs, and that investment in market fundamentals might be a better solution.

This analysis is borne out in the Nigeria country case study. Nigeria has a functioning commodity exchange - the Abuja Securities and Commodity Exchange (ASCE) - which provides a platform for trading contracts on agricultural commodities and solid mineral products. It was expected to help farmers, processors, and traders in agricultural commodities to manage production and marketing risks in the farm sector and therefore to catalyze commercialization and growth in agriculture. However, this expectation is yet to be fulfilled, as the ASCE has struggled to attract significant volumes of trade in agricultural and non-agricultural commodities.

The Ethiopia programme of commodity exchange-based reforms, by contrast, is reported to be providing benefits, at least for coffee. This is attributed to strong state backing - the government has taken over the exchange - but is also said to be because it has outlawed any other means of selling commodities covered by the exchange to the export market. Thus the new system has much in common with the former Coffee Marketing Board. The exchange is claimed to have had 
significant impacts at the farmer level, at least for coffee. ${ }^{109}$ Since it opened in 2008 , there have been over $£ 1$ bn worth of trades and 16 warehouses have been installed across the country. This means that farmers no longer need to transport coffee to Addis Ababa, and so reduces transport costs. Most significantly, there has been an increase in farmers' share of the final coffee price from around one-third to approximately two-thirds.

From the Tanzania country case study comes a warning about state market intervention within a liberalized trade environment (see Box 18).

\section{Box 18: Smallholder cashew farmers and market regulation in Tanzania}

The cashew sector in Tanzania is huge, representing 5 per cent of GDP and involving over 730,000 households. Cashew nut farmers have been forced by the government to sell their produce through the Warehouse Receipt System (WRS) in order to raise the quality of raw and processed products and to reduce the number of middlemen. A new policy has also denied processors the option of buying direct from farmers. The industry regulator, the Cashew Board of Tanzania, sets an indicative minimum price, at a higher level relative to the price that buyers are willing to pay and at which farmers are willing to sell. Because farmers and processors have been forced to trade through the WRS, and also because of declining cashew nut prices in the world market, buyers have gone elsewhere, leaving a large quantity of cashew nuts unsold both on arms and in the warehouses, and exposing farmers to very high levels of risk. Although the WRS has worked well for some crops, such as rice in Chimala in Mbeya, it is not a solution for the cashew nut crop.

Sources: Tanzania country study; UNIDO (2011)

Alternative models could include a tax or other fee levied on the production of a commodity, with funds raised directly invested to raise the economic and social performance of the sector, particularly small-scale producers. ${ }^{110}$

The problem with the former parastatal marketing boards was that they centralized power and control, and this could be a target for abuse and exploitation. The key to success is, then, to avoid moving towards a position where the board is incentivized to exploit its position in the market at the expense of efficiency. This is likely to be different for each country and commodity, but political autonomy and professionalization can definitely help. These have been features of one survivor of the former marketing boards - Ghana's cocoa marketing system, even though it is government-run (Williams, 2009). It proves that marketing boards can play a vital role in market co-ordination, especially when smallholders dominate. But there are also structural characteristics of commodities that make them particularly poorly or well suited to marketing board co-ordination. In the case of cocoa, the long time horizon, export dominance, the importance of quality, the dominance of smallholders, and volatile world prices make it well suited to this form of regulation. The success of the Ghana Cocoa Board can be seen in six dimensions:

- High levels of cocoa production;

- Generous revenue sharing with farmers (the share has been increasing compared with Ghana's liberalized neighbour, Côte d'Ivoire);

- Consistently high cocoa quality;

- Professional and efficient management of cocoa exports (the marketing board is lean and efficient and has a longstanding reputation for fulfilling contractual obligations);

- Lack of corruption;

- A strong credit record. 
Marketing boards for cereals have also had mixed results. A study by Mather and Jayne (2011) using data for the period 1997-2007 showed that the National Cereals and Produce Board of Kenya (NCPB) is succeeding in its quite narrow aim of increasing maize prices and production, so contributing to agricultural growth. Higher producer prices allow for greater investment in inputs. The report seems to corroborate the widely held belief that the NCPB is a powerful force in Kenya and there is also evidence that it has helped to reduce volatility and to stabilize prices. Even so, the majority of Kenyan smallholder households are net purchasers of maize. It seems that even with increased income and productivity, higher prices of maize counteract the gains.

A similar study by Mason and Myers (2011) of the Food Reserve Agency (FRA) in Zambia, which is currently the country's dominant buyer of smallholder maize, showed that the buy price consistently exceeded average wholesale prices. The above-market buy price makes it difficult for the FRA to export maize, unless Treasury funds are available to subsidize exports. FRA activities also stabilized maize market prices throughout the July 1996-December 2008 study period but, as in Kenya, the price effects are regressive, with higher maize prices harming urban consumers and the nearly 50 per cent of smallholders who are net buyers of maize. Higher maize prices are claimed in the study to be helping large-scale farmers and a small number of relatively better-off smallholders (Mason and Myers, 2011: 6).

In Nigeria, the Federal Government has established three Commodity Development and Marketing Companies for arable crops, tree crops, and livestock/fisheries, to be owned and managed by farmers. By promoting production, processing, storage, and marketing, the companies were intended to stabilize prices of agricultural products and ensure remunerative producer prices to farmers. However, they have not been able to deliver on their mandates due to under-capitalization - more than 60 per cent of their call-up share capital is still not paid up.

The commodity exchange in South Africa is considered to be a success, and it plays a major role in price discovery between buyers and sellers - the price is also used as a reference point throughout southern Africa. However, an area of concern is the exchange's perceived lack of penetration and lack of participation by smallholders; it is mostly used by larger commercial farmers (UNCTAD/SFOA, 2006: 50).

\section{Open and competitive markets: competition policy}

Competition policy is needed to prevent potential abuses of market power, especially in increasingly liberalized markets. Its use is not especially prevalent in developing countries Guatemala, for example, has no competition law - although it is definitely growing. There has been a trend towards harmonization of competition policy worldwide, around the US/EU model, which emphasizes the importance of competition for economic efficiency (Farquhar, 2011). Much of this harmonization is achieved thanks to the development of model laws, although 'model laws' is a bit of a misnomer, as in competition policy there is no 'one size fits all' policy (DFID, 2001) and it should be adapted according to the stage of a country's development.

The primary focus of competition law has been on protecting consumers from monopolies or oligopolies (i.e. cartels) in production, manufacturing, and distribution, to compel producers to offer lower prices, better quality, and more choice. One example is the bread value chain in South Africa, where the country's four biggest bread makers were recently convicted of running a cartel at the expense of consumers. But it is notable that the analysis of mergers within South Africa's Competition Act is not just about lessening competition, but also about 'creating opportunities for employment, broadening the basis of ownership and advancing the prospects of small medium and micro enterprises (SMMEs)'. ${ }^{111}$

Consumer-focused competition policy can be a barrier to producer collaboration. Often agriculture has special dispensation under competition policy that allows producer organizations to not count it as price fixing. 
Competition law has generally not been directed at producer welfare, despite evidence that serious competition problems caused by buyer power can occur at a much lower level of market share than seller power on the seller's side. Buyer power needs to be examined on its own terms; traditional seller power analysis may not be appropriate (Vorley, 2003). This discussion about the role of market concentration on incomes, particularly those of smallholders, has even reached the World Bank (Porto et al., 2011).

Competition is much harder to regulate closer to farmers, where informal alliances of buyers create monopsonies ${ }^{112}$ that leave farmers with no alternative buyers. Mobile phone availability and the presence of more traders in the countryside are helping to introduce more competition in many regions.

There are a number of competition-related laws in the Philippines, as identified by Santos (undated). ${ }^{113}$ And while the Philippines Constitution of 1987 prohibits anti-competitive behaviour, penalties for violating competition laws are negligible. The paper by Santos (2010) proposes a comprehensive anti-trust law based on the experience of other countries that have successfully implemented competition policy, but designed to take account of the peculiarities of the Philippine setting. It also advocates for the creation of an anti-trust commission to administer the law and ensure compliance with it. At the time of writing, there were bills pending in Congress (e.g. Senate Bill 3098, Consolidated House Bill) that included these features. Penalties imposed for violations would be quite substantial, ranging from PHP $10-50 \mathrm{~m}$ for individuals and PHP 250-750m for corporations. Proposed penalties for violations involving basic agricultural commodities are three times higher. These policies protect farmers, including from market power such as that represented by cartels, price fixing, and under-pricing of buyers of agricultural produce and processed food products.

Another role of competition authorities specific to supporting small-scale producers and suppliers relates to conditions of approval attached to mergers and acquisitions in the modern retail and manufacturing sector. A highly innovative example recently enacted by competition authorities in South Africa attached conditions of approval to the acquisition of a stake in retailer Massmart by Walmart, in the form of a supplier development fund to empower local suppliers to respond to the challenges posed by the merger. ${ }^{114}$

There are also fair trading legislation or codes such as the 'supermarket ombudsman', which will potentially provide suppliers with real power to act against abuses of buyer power by large UK supermarkets, ${ }^{115}$ and codes of conduct on trading relationships such as the Best Commercial Practices Code (BCPC) in Argentina. ${ }^{116}$

\section{Quotas and other market preferences for small-scale and family farmers}

Another way that public policy can shape markets in support of small- and family-scale farming is through quotas and other market preferences, especially in public procurement. There are many interesting examples around the world - especially in Brazil - some of which are summarized below.

\section{Brazil National Programme for the Production and use of Biodiesel (PNPB)}

The Brazil National Programme for the Production and Use of Biodiesel has an explicit focus on incorporating small farmers into the value chain. This has taken the form of also looking to encourage castor bean production, as this crop can be grown on small farms in conjunction with subsistence farming. The central policy instrument used to include small-scale farmers has been the 'social label' scheme. If companies meet targets for procurement from small farms, they are guaranteed purchases and they are also exempt from certain taxes (Zapata et al., 2010). However, while social inclusion and poverty reduction have been the main objectives of the PNPB, participation (particularly in the poor Northeast region) has been very low and some of those who have participated have faced economic losses owing to price fluctuations in the 
fuel market. A particular challenge of the programme has been to combine the production of both small- and large-scale farmers. The familiar shortfall in farmers' voice in programme design (Section 2.4) also applies here. One study points out: 'A chief source of disincentives is small farmers' lack of engagement in the programme design and dominance of institutional and cultural arrangements that exclude small farmers from mechanisms that would link them to external agencies. This suggests the need for policy intervention based on repeated interactions and community governance mechanisms, building trust and common understanding about potential course of action' (Zapata et al., 2010: 21).

\section{Brazil Food Acquisition Programme (PAA)}

The Food Acquisition Programme is an important part of Brazil's food security policy framework, Zero Hunger (Fome Zero). Like the biodiesel programme, it is also explicitly designed to include family farmers and contribute to economic development, but it appears to have succeeded in being more inclusive (Chmielewska and Souza, 2010). A case study in northeast Brazil shows that the PAA offers benefits both to farmers (secure markets with guaranteed prices, which encourage reinvestment in production, plus improvements in organizational capacity) and lowincome consumers (in terms of food security). Tangible benefits are seen for those who participate, thanks to higher prices, stable purchasing that allows increased investment (not funded on credit), and increases in quality. Between 2003 and 2008, the Brazilian government spent $\$ 1$ bn to buy $2 \mathrm{~m}$ tonnes of food through the PAA. In 2008, about 120,000 farmers were selling products within the programme. There is a thorny question of dependency: 'if the programme ends, its beneficiary farmers will return to conditions similar to those they experienced before their participation in the programme' (Chmielewska and Souza, 2010).

\section{World Food Programme Purchase for Progress (P4P)}

Although not strictly national government policy, the P4P programme is a very large test case of linking public procurement and smallholder development. It is aimed at 500,000 smallholder farmers in 21 countries, over five years from September 2008 to September 2013, with a full evaluation to be released in 2014. P4P is testing innovative ways to buy staple foods and to promote marketing opportunities for smallholder farmers. It is designed to link WFP's demand with the expertise and resources of partners who support farmers to achieve better yields, reduce their losses after harvest, and improve the quality of their staple crops. It is also linked to the commodity exchanges described above; indeed, P4P is providing a rationale for those exchanges.

In progress to date, more than 1,000 farmers' organizations (FOs) representing more than 1.1 million farmers (500,000 of whom are in Ethiopia) have been identified to participate in P4P. So far, over 200 of those FOs have contracted to sell food commodities to WFP. Over 116,000 farmers, warehouse operators, and small and medium traders have been trained in skills including organizational management, farming techniques, quality control, and post-harvest handling. Over 207,000 tonnes of food in 20 countries have been contracted through P4P.

On the negative side, a mid-term evaluation undertaken by the Overseas Development Institute (ODI) for WFP pointed to insufficient analysis in the design of the programme of the key problems facing smallholders, particularly women, in the value chain. ${ }^{117}$ Risks to farmers, such as harvest failures and price crashes, have been insufficiently recognized, while P4P purchases have generally been less cost-efficient than regular local purchases. The rate of defaults is significant, mostly because P4P is quality-conscious and also because farmers side-sell, suggesting that prices might not be that attractive to them given the extra costs of dealing with P4P, especially protracted price negotiations, late payments, and payments through FOs.

P4P beneficiaries tend to be among the more productive smallholder farmers. Preliminary evidence shows that the gross income gains that farmers are making from the programme are about half the target of $\$ 50$, because the price premium is modest and volumes are low. However, supply-side partnerships and capacity development projects are showing some signs 
of increasing productivity, and commercial banks are starting to offer credit to FOs against security of forward contracts or warehouse receipts. Procurement through new market institutions compared with direct engagement with FOs seems to be less costly and more sustainable, as they introduce resources and institutions which incentivize local market actors, but the benefits may be less traceable and attributable.

Another form of market modality to protect the position of small-scale producers in markets is through restricted access to export quotas. Research done in the fisheries sector, with relevance to agriculture, shows how the government of Belize is providing preferential access to export markets, by building, since the 1960s, a system of co-operatives and giving them an exclusive monopoly on exporting lobsters (Monnereau and Helmsing, 2011). Another example comes from the case study portfolio of the Regoverning Markets programme, in which phytosanitary export standards in Mexico were controlled by small- and family-scale avocado producers. ${ }^{118}$

Market preferences allow a more careful targeting of market interventions than, say, subsidies on inputs such as fertilizer. However, the high costs of the Brazilian models, representing considerable financial transfers to the small farm sector, raise questions as to whether least developed countries (LDCs) can afford this approach. But even the ambitious Brazilian programmes are dwarfed by public financing to export-oriented agriculture; the public budget in Brazil for the 2009-10 agricultural year allocated over six times more resources to the agribusiness sector than to family farming (Chmielewska and Souza, 2010: 25).

\section{Public policy and private standards}

Markets for agri-food products covered by private 'voluntary' standards and multi-stakeholder sustainable commodity initiatives are growing rapidly. ${ }^{119}$ Supermarkets and food manufacturers and their financiers impose increasingly stringent food safety, quality, and traceability requirements, partly as a response to consumer concerns about the safety of the produce they buy and also due to their legal requirements under food safety laws. Industry regulations that drive traceability and standards are also at play; for example, in 2001 the US Chocolate Manufacturers Association adopted the Harkin-Engel Protocol to end the 'worst forms of child labour' in cocoa farming. Private sustainability standards are usually associated with high-value products, especially fruits and vegetables and established consumer niches, but they will be increasingly common features of mainstream trade in commodities, and are a defining factor of globalization. ${ }^{120}$ Investors in agriculture aiming for export markets are likely to require compliance with at least one private standard.

These standards and requirements apply to suppliers whether they farm their own plantations or source produce from small-scale producers. But it is easier for companies to trace produce and demonstrate compliance if they control the value chain. Setting up traceability systems in ventures that source produce from thousands of farmers is possible, but it requires more work; there are considerable economies of scale.

Although these standards are private institutions, they are part of the intense competition between nations for export markets. Thus policy makers are often drawn into the battle to grow or defend markets through private standards. They may be lobbied to subsidize certification or farmer training. They may be asked to invest in infrastructure, such as laboratories and standards bureaux. Donors and NGOs may also be advocating a strategy of export-led growth in high-value (and high-standard) agri-food products, with promises that these markets will 'work for the poor'. There is also the implicit threat that, by doing nothing, countries risk losing markets to other exporting nations, or even risk a national boycott by leading agri-food traders, processors, and retailers. Last but not least, CSOs may be mounting campaigns against standards and initiatives, as has been seen with Round Table for Responsible Soy (RTRS) certification in Latin America. 
Private standards for food safety are closely attuned to regulatory requirements in importing countries (Henson and Humphrey, 2009). In principle, private standards can benefit exporting countries as well as value chain businesses. These standards can offer developing country policy makers an opportunity to use the power of the market to support national policies to improve the safety and sustainability of agricultural production. But 'sustainability' standards operate on much more contested ground, where CSOs and businesses are each defining 'sustainability' and where production standards are being set far ahead of public regulation. Sustainability standards, if designed to reassure consumers in destination countries, may be very much at odds with national goals and priorities for sustainable development in exporting countries. These standards present particular challenges for small-scale producers. There is clearly a role for public policy to level the playing field for smaller-scale producers.

The kind of interventions that policy makers can support to help do this include:

- Training and support services: there may already be schemes associated with private standards that tailor training and support to certification for smallholders. An example is the Soy Producer Support Initiative led by Solidaridad, WWF, and the Round Table on Responsible Soy (RTRS); ${ }^{121}$

- Assistance for group formation;

- Subsidized audits and certification;

- Preferential access to inputs and services, especially finance, for certified producers;

- Public procurement, stipulating certified foodstuffs from small-scale suppliers within public procurement contracts;

- Supporting the participation and voice of marginalized groups such as smallholders in the standard-setting process;

- Promoting smallholder-specific elements with regards to standards and certification, with group certification being the most obvious adaptation. Smallholder-specific elements have been built into FLO and Utz Certified systems; ${ }^{122}$

- Direct engagement with, and influence over, the standard-setting process to achieve some alignment with national policies for sustainability and poverty reduction;

- Supporting the establishment of nationally adapted standards, which can be benchmarked against a global private standard (UNCTAD, 2007);

- Investment in a local certifier, such as Africert. ${ }^{123}$

- Each policy instrument needs to be costed, and weighed against alternative scenarios, including alternatives to high-standards markets.

In order to ensure that women producers will benefit from such policies and support programmes, gender-specific policy measures are likely to be required. For example, training services need to be structured to ensure that women farmers benefit, for example by recruiting a given proportion of female trainers and ensuring that training techniques used are accessible to illiterate farmers. Similarly, assistance for group formation needs to take into account constraints for female participation in producer groups; policy makers should, for example, ensure that any new groups adopt membership criteria that are inclusive of women (International Trade Centre 2012). Finally, if lobbying private certification schemes to include smallholder elements, specific efforts should be made to promote the inclusion of gender criteria in these elements - along the lines of those adopted by Utz and Fairtrade standards. ${ }^{124}$

\section{Space for small farmer development within trade policy}

Despite the tendency to use trade measures on behalf of consumers rather than producers (see Box 14), measures - especially protective tariffs - have been introduced, following the collapse of the Doha Round of trade talks, from 2007 onwards that have improved commercial incentives for domestic producers. The AFRINT authors recorded 'positive effects on domestic staple food 
production'. This is potentially a very important observation, and echoes justifications for treating small-scale farming in trade policy terms as an infant industry to create incentives for domestic production and investment. It also suggests that the lessons from Asian development are about phasing in opening markets: knowing what part of the economy to open up to competition, and when.

In the four focus countries, Tanzania included in its tax reform proposals in the 2010/11 budget an element of protecting agricultural products against highly subsidized imported products.

Nigeria too has announced a policy whereby revenue derived from increased levies on agricultural commodity imports (starch, sugar, wheat, and rice) should be used to support domestic production. If this policy is effectively implemented, it is likely to be an incentive for small-scale farmers to increase production of the commodities involved, especially rice, maize, and wheat.

The topic of policy space for small farmer development within trade policy agreements needs more analysis, including the appropriate sequencing of trade liberalization for building local markets.

\subsection{SUMMARY OF KEY FINDINGS, SECTION 4}

This section has described how, although market governance is important in ensuring fair and transparent trade between corporate investors and small-scale producers, many of the policy levers that make markets work better for small-scale producers do not have much in common with the needs of investors or the demands of modern value chains. For those producers, who are rarely formally organized in the market, it has looked at the policy levers that can support their position in markets. Policy levers are used to strengthen organization and market power of small-scale producers, provide a greater diversity of market outlets, make standards and certification work better for small farmers, improve price stability and producer share of market value, and/or provide market preferences for small- and family-scale producers, for instance in export quotas or public procurement, or through protecting small farm sectors from import competition.

Each set of levers has its own set of opportunities and risks. Getting the legal and tax status of producer organization right for them to be able to compete effectively in markets is an obvious policy lever. However, formal POs and co-operatives are not always the best or even most accessible way for producers with few assets or for women to co-operate to compete. Investment in diversity of market channels, and supporting or upgrading the informal sector which still feeds the majority of low-income consumers in developing countries - should under many circumstances be a top priority for policy makers. The same goes for heavy investment in market regulation, when simpler upgrading of local market infrastructure and the break-up of cartels may already get markets working much more effectively for smallholders.

Key policy areas related to market governance that are important from a gender perspective are laws and policies governing co-operatives and POs, policies relating to market diversity, policies supporting more equal intra-household power relations, and policies relating to private standards. With regard to co-operative laws, few directly discriminate against women; however, some include stipulations that indirectly discriminate against women's membership. Obviously, where they exist, these clauses need to be repealed; however, in most countries the root causes of women's unequal participation in co-operatives and other POs are socio-cultural, so policy efforts are best focused on effective implementation of affirmative actions and policies that challenge these norms. In addition, policy initiatives to channel support for informal groups are important, given women's predominance in these organizations.

As for market diversity, informal markets are particularly important for women, so policies to strengthen rather than undermine these markets are needed. In addition, specific measures to address women's specific constraints to market access are necessary. In order to ensure that 
women benefit from initiatives to improve the producer share of market prices, policies to promote more equal intra-household distribution of resources are critical. Finally, policies that aim to increase smallholder participation in private certification schemes need to ensure that relevant support services provided are gender-sensitive, and that efforts to encourage private certification schemes to incorporate smallholder standards/elements also incorporate gendersensitive criteria.

The policy levers that can influence market governance either in support of agro-industrial development or in support of smallholders and women are summarized in Table 4. 
Table 4: Market governance

\begin{tabular}{|c|c|c|c|}
\hline \multirow[t]{2}{*}{ Policy lever } & \multicolumn{2}{|l|}{ Policy intent } & \multirow{2}{*}{$\begin{array}{l}\text { Implementation } \\
\text { issues }\end{array}$} \\
\hline & $\begin{array}{l}\text { Policies that support } \\
\text { smallholders }\end{array}$ & $\begin{array}{l}\text { Policies that support } \\
\text { women }\end{array}$ & \\
\hline $\begin{array}{l}\text { Producer } \\
\text { organizations }\end{array}$ & $\begin{array}{l}\text { - Laws and taxes to support } \\
\text { smallholders to compete } \\
\text { - Protection of autonomy of } \\
\text { co-operatives } \\
\text { - No taxation of intra-co- } \\
\text { operative trade }\end{array}$ & $\begin{array}{l}\text { - Remove clauses that } \\
\text { (indirectly) } \\
\text { discriminate against } \\
\text { women } \\
\text { - Affirmative actions } \\
\text { - Support informal } \\
\text { groups }\end{array}$ & \\
\hline $\begin{array}{l}\text { Diversity of } \\
\text { market outlets }\end{array}$ & $\begin{array}{l}\text { Public support to upgrade } \\
\text { traditional wholesale } \\
\text { markets and informal } \\
\text { sector } \\
\text { - Enable participation of } \\
\text { private sector and co- } \\
\text { operatives } \\
\text { - Simple infrastructure } \\
\text { improvements, e.g. } \\
\text { calibrated scales } \\
\text { - Protection of traditional } \\
\text { markets e.g. zoning } \\
\text { modern retail }\end{array}$ & $\begin{array}{l}\text { Support or upgrade } \\
\text { informal sector, } \\
\text { especially local } \\
\text { markets, street } \\
\text { vendors, wet } \\
\text { markets } \\
\text { - Address women's } \\
\text { market access } \\
\text { constraints }\end{array}$ & $\begin{array}{l}\text { Negative } \\
\text { attitudes to the } \\
\text { informal sector }\end{array}$ \\
\hline $\begin{array}{l}\text { Market co- } \\
\text { ordination }\end{array}$ & $\begin{array}{l}\text { Investment in market } \\
\text { fundamentals e.g. } \\
\text { warehousing and storage, } \\
\text { market information, } \\
\text { transparent commodity } \\
\text { exchanges } \\
\text { - Effective market regulation } \\
\text { to co-ordinate markets and } \\
\text { manage producer risk, e.g. } \\
\text { marketing boards }\end{array}$ & & $\begin{array}{l}\text { Focus on } \\
\text { commodity } \\
\text { exchange } \\
\text { market } \\
\text { fundamentals }\end{array}$ \\
\hline $\begin{array}{l}\text { Competition } \\
\text { policy }\end{array}$ & $\begin{array}{l}\text { - Break-up of cartels } \\
\text { - Conditions of approval for } \\
\text { M\&As } \\
\text { - Fair trading laws or codes }\end{array}$ & & $\begin{array}{l}\text { - Prioritizing } \\
\text { urban } \\
\text { consumers over } \\
\text { producers in } \\
\text { policy }\end{array}$ \\
\hline $\begin{array}{l}\text { Quotas and } \\
\text { market } \\
\text { preference }\end{array}$ & $\begin{array}{l}\text { - Incentives for procurement } \\
\text { from smallholders } \\
\text { - Public procurement } \\
\text { policies } \\
\text { - Smallholder access to } \\
\text { export quotas }\end{array}$ & & \\
\hline $\begin{array}{l}\text { Public } \\
\text { policies and } \\
\text { private } \\
\text { standards }\end{array}$ & $\begin{array}{l}\text { Create a level playing field } \\
\text { for smallholders, e.g. } \\
\text { training, subsidies }\end{array}$ & $\begin{array}{l}\text { - Gender-sensitive } \\
\text { support criteria and } \\
\text { services }\end{array}$ & \\
\hline Trade policy & $\begin{array}{l}\text { Treat small-scale sectors } \\
\text { as an infant industry, } \\
\text { phasing in market opening }\end{array}$ & & \\
\hline
\end{tabular}




\section{CONCLUSIONS: POLICY AND ADVOCACY PRIORITIES FOR INCLUSIVE AGRICULTURAL INVESTMENTS AND MARKET DEVELOPMENT}

More investment is required for agriculture to meet the growing list of expectations of the sector. Despite the Maputo Declaration, public agricultural investment and institutions have been allowed to weaken in response to the decline in agriculture's relative contribution to GDP. Much attention has instead been paid to the facilitating environment for private investment in agriculture, encouraged by international organizations and donors. Many organizations, from the FAO to the WEF, have made very similar calls to embrace the private sector as the main engine for global food production. Donors have provided investment advice and technical support aimed at supporting developing country governments to maximize commercial investment. Bilateral and multilateral trade and investment treaties have promoted investment liberalization while protecting foreign investment. Policies in investors' home countries have provided financial and other incentives and support for companies operating overseas. Investment is now indeed flowing back into agriculture, much of it from commercial investors rather than governments. The focus of that investment is on agricultural land and industrialscale agricultural production. In an era of a global squeeze on natural resources, high commodity prices, and insecurity of supply, land has become king.

In view of this new era, this report has taken a new look at policies and their leverage over agricultural investment and the working of markets to support national strategies for inclusive agricultural development. Its focus has been on commercial investment, but its conclusions can also help to guide policy around other forms of investment. The conclusions and recommendations are mainly high-level, framing the policy landscape and summarizing the key issues. The framework of this analysis can, however, be picked up by groups to apply to specific examples of policies at the local level.

\section{WHOSE INVESTMENT?}

Despite the attention given to commercial investment, the bulk of investment in agricultural production is still made by small-scale farmers themselves (CFS, 2011), who invest their own savings as well as small loans from the informal financial sector. The investment climate that supports smallholder investment and the investment climate that supports corporate investments in agriculture, while having much in common, are not the same.

In general, commercial investors only see large returns on investments from large-scale agriculture. They will usually opt for plantation and estate scales, which may include smallholders as outgrowers. However, this is a narrow definition of inclusive agricultural investment. A broader-based definition of inclusive agriculture is needed, in which the policy environment to support smallholder investment in agriculture is more about domestic markets, including the informal sector. When domestic markets and trade are reliable, smallholders will invest in their land and productivity to supply the market. What is especially important for smallholders is private investment in first-level processing, such as in oilseed crushing, that generates a stable market and local value addition.

Policy makers have been rather oblivious to this difference between investment in agriculture and investment for agriculture; the Tanzania country report, for example, states that farmers are not even considered as investors within the investment policy framework. It elaborates, 'Among 
the specific policy measures that Tanzania has used to attract and retain investors [is the] offering of various investment incentives as stipulated in the Tanzania Investment Act 1997. Generally, these incentives are in favour of corporate investors. Smallholder farmers do not qualify for these rather lucrative incentives. Partly, these farmers are not considered as investors. Even if they were, they do not qualify for investment incentives.' In an investorfriendly climate, small-scale producers have, as described in this case study, 'less of what it takes to deal with the market forces of supply and demand, and less voice to influence policies in their favour'.

\section{POLICY MATTERS}

This report shows that policy matters. The policy environment can shape investments and markets in ways that affect the structure of agriculture and smallholders as a productive sector, and women in smallholder agriculture in particular. It can drive agricultural investment that is dominated by large commercial interests, so that agriculture will follow a two-tier development path, with plantations or estates (perhaps with some outgrower schemes tagged on) as outposts of global agribusiness. Or it can support a mixed structure with strong linkages between large- and small-scale production and strong economic multipliers in the domestic economy.

This report has treated the policy levers controlling investment and market governance as two separate elements that can make or break inclusive and resilient growth in the agricultural and food sectors. It also shows that, in drawing conclusions and recommendations, it is time to knock down the walls between these two areas, because they form an interlinked policy environment. Policies that are effective in attracting investment in agricultural production will create outposts of global agribusiness operating in isolation from the majority of smallholdings and from domestic markets, unless those domestic markets are themselves subjects of investment and good governance (as set out in Section 4). And if the conditions are right in domestic markets for smallholders and other entrepreneurs to invest in production, then states no longer need to feel so reliant on commercial investment at all costs to kick-start agricultural development.

Despite much diversity in contexts and policies, prevailing policy frameworks are skewed against small-scale farmers, and against women in smallholder agriculture. Features of land tenure regimes in many countries receiving investment, coupled with tax incentives and other devices aimed at promoting investment, favour large land deals over models of agricultural investment that are inclusive of small-scale producers. Unless the policy framework is rebalanced, there are real risks that the renewed interest in agricultural investment will foster exclusion. In order to promote inclusive agricultural development, this situation needs to be reversed.

The four country case studies undertaken for this report have provided practical examples of innovations in policy design and implementation that have improved the inclusiveness of agricultural development, although it can be difficult to draw firm causal links between policies and their impacts. Examples of innovations include giving voice to local producer interests, such as decentralization of land management responsibilities in Tanzania and free, prior, and informed consent in the Philippines. The challenge in many of the examples identified in the research is to properly implement progressive policies in the face of major power imbalances between beneficiaries and vested interests seeking to maintain the status quo.

There are also policy levers that could promote more inclusive models of agricultural investment but that remain untested by governments. Examples might include reversing current fiscal incentives favouring land acquisition by developing incentives for more inclusive investment models and policies that attach conditionalities to investments to link with small-scale farmers and women, in order to ensure wider economic benefits. There is an important research agenda to expose and test these levers. 
From a gender equality perspective, the report shows that policy also matters - but in a slightly different way. The research demonstrates that patriarchal socio-cultural norms and practices, rather than gender-discriminatory policies, are usually the root cause of gender-unequal outcomes from agricultural investments and markets. Crucially, however, the right types of policy, as outlined in Section 2.3, are both necessary and potentially effective in challenging and ultimately changing these underlying socio-cultural norms, and hence improving the gender impacts of investments and markets.

What is also clear from the report is that 'pro-smallholder' policies are in themselves not enough to ensure gender-equal outcomes; nor are policies that target only isolated aspects of women's lives. Instead, what is needed is the adoption of a gender-sensitive approach to both the design and implementation of all relevant policies; i.e all policies must take into account the different needs and constraints faced by women and men, and respond to these different needs by incorporating appropriate policy measures. This includes the support of targeted measures to tackle the specific constraints that women face (e.g. their time constraints resulting from their domestic responsibilities), and the adoption of affirmative measures to reduce existing gender inequalities in access to critical services and decision-making forums, e.g. the establishment of gender quotas to ensure a minimum level of female representation on co-operative boards.

\section{ADAPTING POLICY TO DIFFERENT ‘RURAL WORLDS'}

This report has pointed out the dangers of 'one size fits all' policies that ignore the diversity of smallholder households and livelihoods, and frame smallholders as scaled-down versions of large farmers. While policy can support connections between commercial investors and smallscale producers, such as through oversight of contracts, incentives for producer organization, and oversight of trading relationships between producers and buyers, these value chain linkages are more likely to work best for Rural World 1, which involves only the top 2-10 per cent of small-scale producers, who have the assets and access to capital, organization, information, and infrastructure to 'step up' to formal and co-ordinated markets (see Box 5). The report also notes that public policy is not necessary for much of what makes contract farming and outgrower schemes fair and inclusive; that is contingent on a firm's private actions and business model. However, these instruments of policy may be poorly attuned to the realities of most small farm agriculture and may therefore create a big gap between intent and reality.

The Tanzania country report exemplifies that gap; in many areas, such as on the slopes of Mount Kilimanjaro, farmers' assets of land and equipment are far less than what is needed for a successful transition to commercial agriculture. Also, they cannot meet minimum requirements which include business licences, tax documents, business plans (or funds to pay an expert to write them), collateral, audited accounts, membership of a co-operative, or an outgrower contract with a large farm - for accessing the more attractive rates offered by commercial or development project finance. Many of the country reports show how financial products can be very exclusionary in their collateral requirements.

Improving the institutions and governance of the 'traditional' and informal trade that dominates Rural World 2 requires a different set of approaches than those applied to the governance of vertical value chains. The majority of farmers in Rural World 2 are not formally organized in the market. This is a more horizontal sector-wide approach and the sort of basic policy preference for agriculture and women outlined in Section 2. Much can also be achieved with simple investments in physical infrastructure, such as local market spaces and investment in local processing, though warehousing and storage, market information, or transparent commodity exchanges. But governance is also important to regulate markets and reduce producer risk. These investments and governance help ensure greater resilience for relatively vulnerable small-scale producers and allow greater scope for risk-taking, particularly by women and smallscale producers. 
For people in Rural World 3, who have few land or other assets, wage labour is important, and there are issues of poor working conditions in plantations and packing houses that also need to be addressed through policy and business practice. 'Soft' infrastructure is important, such as education and health care, as well as social protection. Integrated social protection mechanisms, such as India's labour laws, can reduce vulnerability to shocks and can also build infrastructure such as irrigation systems, which in turn can build climate resilience.

Redistributive reforms are also needed to increase access to land and other natural resources.

Policies also need to reflect the different realities of rural women compared with those of rural men. Thus, a household may have Rural World 1 characteristics by virtue of the land and assets belonging to the male head of household, but his wife may herself have Rural World 3 characteristics (few land or other assets in her own name), and hence her main employment activity is as unpaid labour on her husband's farm - typically receiving little reward for her efforts. Thus, policies that might help increase the incomes of mostly male Rural World 1 smallholders are unlikely to yield much benefit to their wives, unless specific policies are implemented to promote more equal intra-household distribution of wealth.

And because rural women as individuals tend to have few land or other assets, they also share the characteristics of Rural World 3 smallholders in that wage labour is a potentially important source of income. As noted earlier, due to their poor access to land and other productive resources, for most women participating as a smallholder in outgrower schemes is unrealizable; yet waged labour opportunities - especially in packhouses and processing units - can and do present a more easily accessible form of income-earning activity. The implication is that what counts as an 'inclusive' model of agricultural investment looks very different from the perspectives of women and men.

Policy priorities for the three 'rural worlds' are illustrated in Figure 2.

Figure 2: Examples of adapting policy priorities to the three 'rural worlds'

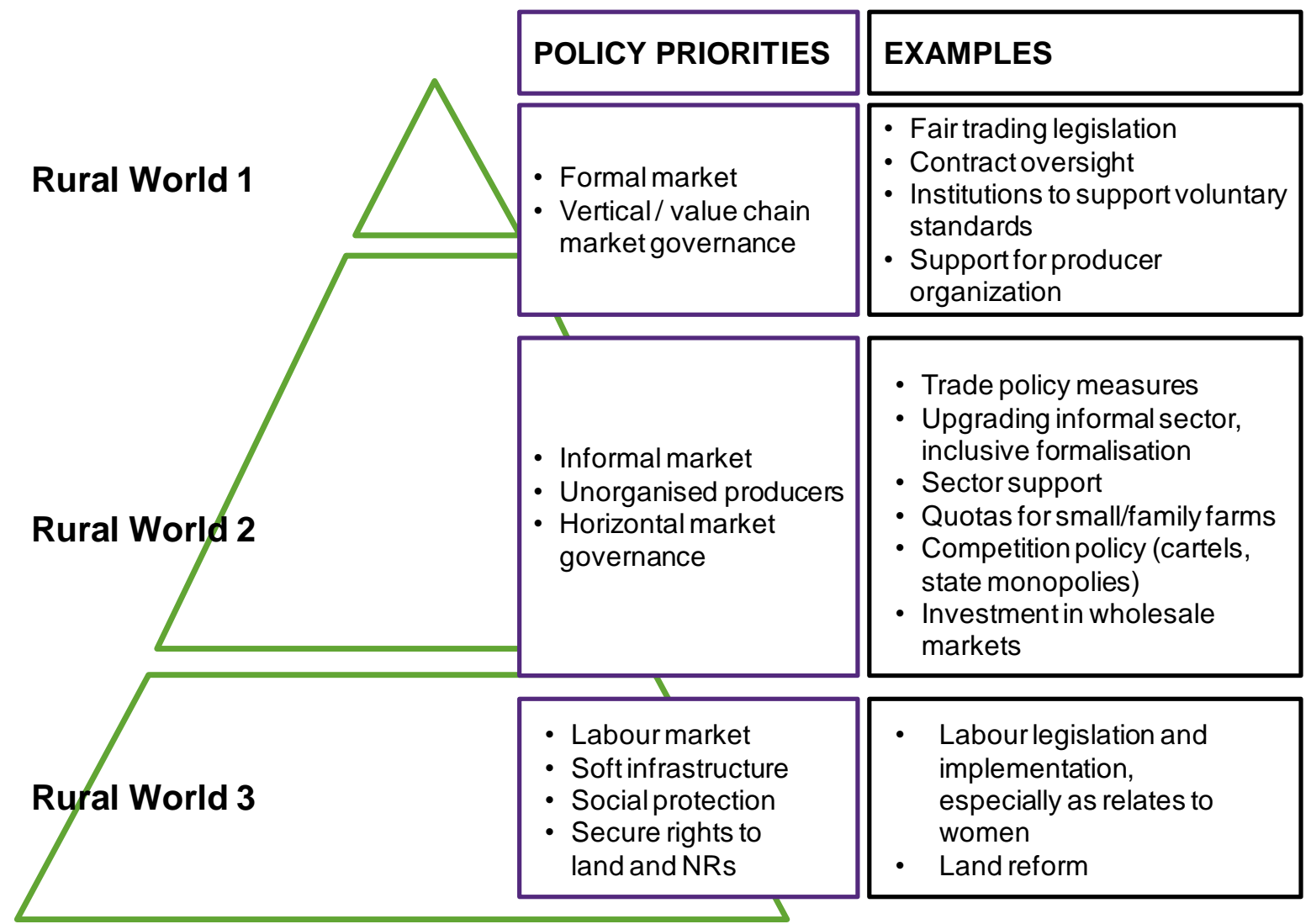




\section{THE GAPS BETWEEN INTENT, DESIGN, AND IMPLEMENTATION}

What comes across strongly in all the country reports is the gap between good intentions and what is happening on the ground. There are many good policies on the statute books - such as Tanzania's Agricultural and Livestock policy and the Kilimo Kwanza initiative - that recognize that agriculture will continue to play a central role in national economies, and that seem to discriminate in favour of smallholder farmers in general and women in particular. However, what matters most is not only recognizing small-scale producers and women in agriculture but also implementing the policy in a way that removes the challenges faced by smallholder farmers and by women. The country reports and other literature, including Oxfam reports, give some positive examples of innovation in policy programming, such as the space created for small farmer voice - supported by capacity building - in influential policy institutions such as the Sisal Board in Tanzania or the national forum for investment in small-scale agriculture in Ethiopia (section 2.4).

The Guatemala and Tanzania country studies in particular show how the situation in the field is completely different from the stated intent of the policies (sections 2.2 and 2.4). Furthermore, incentives for smallholders may be siphoned off through rent seeking - this is reported in the Nigeria study, where non-genuine 'farmers' have been hijacking incentives provided for smallholders. The Ogun state government is to manage the sum of N1bn (US $\$ 6.3 \mathrm{~m}$ ) for onlending to small-scale farmers, but until now no money has been disbursed, and the state has been busy trying to identify genuine farmers.

Effective policy requires not only well thought out policy design, but also sustained investment in implementation including capacity strengthening of government agencies and regulators, mechanisms for dispute resolution and budget allocations that reflect policy intent.

The gap between policy intent and implementation is perhaps most clear-cut in relation to gender equality. As already noted, gender-blind policy implementation results in gender-unequal outcomes. This phenomenon is widespread across all areas of policy, but one pertinent example has been the tendency of land titling programmes to grant sole title to (usually male) heads of household, resulting in many wives losing their secondary land rights, which were previously recognized under customary law. The capacity and influence of 'national machineries' responsible for promoting gender equality objectives need to be strengthened and there is a need to address the conflicts that frequently arise between progressive statutory law, on the one hand, and customary norms that perpetuate gender inequality, such as patriarchal land allocation, on the other.

\section{POLICY ANALYSIS AND POWER}

Addressing policy implementation gaps leads inevitably to the issue of power. Without a political analysis, there is a risk of assuming that politicians choose policy in a socially optimal way. There is also a risk of constructing a normative analysis that focuses on technical solutions to the challenges of economic liberalization. In addition, there is a risk of tacitly endorsing the macro-economic and political roots of poverty and thereby reducing the policy aims of sustainable development to defensive strategies to alleviate poverty and reduce environmental degradation (Vorley, 2002).

Vested interests undermine socially optimal outcomes. The majority of governments in subSaharan Africa have retained ownership in agricultural land, which has allowed them to make large areas available to commercial investors and which makes policy so loaded with conflicts of interest. With markets, governments have in general stepped out of big interventions in their operation during structural adjustment, though with some major exceptions and some reverses of this trend, as noted in section 4.1. The deregulation of the ACMP Act in India is moving very 
slowly, as the market yards (mandis) are an important source of income for municipal governments and politicians. Market fees have become important for city budgets and also the focus of rent seeking by some officials (Tschirley et al., 2010).

These examples show that lobbying and advocacy must not stop at the point of new policy introduction, but must continue to ensure delivery on the policy and dedicated interventions in support of smallholders and women, and prevent unintended consequences, such as the risk of the land pillar of Kilimo Kwanza actually favouring corporate investors. Rather than risking more policy inflation without implementation, the Philippines report describes a proposal to improve implementation of the current policies that relate to agricultural investments (e.g. agricultural venture agreements) by reviewing existing bottlenecks and through the passage of the National Land Use Act and the review, updating, and alignment of land use plans and policies by various local government units.

Effective implementation is central to the success of specific gender laws and policies. Since these policies usually focus on influencing and supporting other government departments to mainstream gender issues into their day-to-day activities, a key policy lever is therefore to ensure that the national machinery dedicated to promoting these policies is given sufficient status, power, and resources to really influence the actions of other government departments. Thus, in relation to agricultural investments, gender policies must not only include appropriate objectives and targets (i.e. policy intent); the machinery responsible for implementing these objectives must have sufficient political clout and resources to bring about attitudinal and behavioural changes in relevant government departments, including ministries of agriculture and co-operatives, land reform and land administration bodies, and agencies involved in regulating agricultural investments. Policies may not necessarily be anti-women, but because they are gender-blind they may reinforce pre-existing inequalities and may not achieve changes in attitudes. Or with land, policies that recognize customary tenure may again reinforce inequalities. Long-term interventions may be required to build capacity and change attitudes.

Thus it is important to not just look at the policies, but at the conditions under which those policies have been made to work. Policy infrastructure is as important as market infrastructure. The final question then arises as to the investments that are required for inclusive policy. That has much to do with transparency and accountability, to allow citizen oversight. But it also has to recognize that the world of smallholder agriculture and its associated trade is largely informal, and out of reach of most instruments and institutions of public policy.

\section{WHAT ROLE FOR PRODUCER ORGANIZATIONS?}

It is widely stated that the commercial and political interests of small-scale producers are best bridged by producer organizations, including co-operatives, and their federations. As well as 'co-operating to compete' with commercial investors, expectations of a policy role for POs are also high; for instance, to advocate for public investment in domestic markets. It is right to acknowledge the exclusion of smallholders and women from the policy debate, and the importance of producer organization and federations as a wider interpretation of 'inclusiveness'.

However, this report has presented a mixed picture of formal POs in policy. Firstly, commercial and policy activity require different skill-sets, while the reality of POs is that they tend to have low human and financial capacity to fulfil a complex and highly demanding mandate.

Recommendations for producer organization can also be just another box to tick, and may be based on a misunderstanding of smallholder agency and the way that formal POs can reinforce rather than break down pre-existing disparities of gender and wealth. Places where public policy is formulated are often viewed by smallholders as being distant from, and even irrelevant or hostile to, their day-to-day realities. ${ }^{125}$ 
We must, however, not overlook the instances where dynamic POs, such as in West Africa, have been able to coalesce their political influence, especially against large-scale land acquisition. And women's collective action can be a powerful force for change, as Oxfam's recent research has shown (Baden and Pionetti, 2011). Government policy can play an important role in supporting women's organization, both by promoting affirmative measures to increase women's representation in formal, mixed-gender producer groups, and also by ensuring that informal groups (where the vast majority of organized women are found) can access key services and be included in policy design.

\section{CLOSING COMMENTS}

Some commercial investments in agriculture are undesirable under any circumstances, for example if investments lead to large-scale clearances; or have no connection to or multipliers with the domestic economy; or privilege just a small group of the rural population; or make no contribution to domestic food security.

But there is a strong economic rationale for a disaggregated approach to investment that caters for the three rural worlds, to bring better market opportunities, technology, and - of particular importance to the landless and women - jobs, as well as reforms that increase their access to and control of natural resources. The nature and relative importance of policy levers will vary in different contexts - such as the extent of landlessness. But if agriculture is to support investment in the smallholder sector, then policy will need to do more than attract corporate investment. It will need to recognize smallholders themselves as the main investors in agriculture. Policy biases and structural exclusion of smallholders and of women will have to be tackled with less tokenism and more vigour, going beyond policy formulation to implementation.

As we head into an uncertain era of extremes in commodity prices, climate change, and generation change, with disillusionment with farming livelihoods deterring young people from going into farming, getting this policy environment right for investments and markets is more important than ever. 


\section{BIBLIOGRAPHY}

Research was carried out for this report in four countries, and the resulting country case studies are listed below.

\section{Guatemala country report}

'Opciones de política para las inversiones agrícolas y la gobernanza de los mercados en apoyo de la agricultura a pequeña escala' by Guillermo Díaz, Instituto de Investigaciones Económicas y Sociales (IDIES), Guatemala, (unpublished).

\section{Nigeria country report}

'Policy Options for Agricultural Investments and Governance of Markets in Support of SmallScale Agriculture in Nigeria' by Prof. Aderibigbe S. Olomola, (forthcoming 2013).

\section{Philippines country report}

'Policy Options for Agricultural Investments and Governance of Markets in Support of SmallScale Agriculture in the Philippines' by Larry Digal, School of Management, University of the Philippines, Mindanao (unpublished).

\section{Tanzania country report}

'Policy Options for Agricultural Investments and Governance of Markets in Support of SmallScale Agriculture: Tanzania Country Report' by Honest Prosper Ngowi (forthcoming).

\section{References}

Adenew, B., and F. Abdi (2005) 'Land Registration in Amhara Region, Ethiopia', London, IIED.

Anseeuw, W., L. Alden Wily, L. Cotula, and M. Taylor (2012) 'Land Rights and the Rush for Land: Findings of the Global Commercial Pressures on Land Research Project', Rome, International Land Coalition. http://www.landcoalition.org/cpl/CPL-synthesis-report (Accessed 26 November 2012)

Asian Development Bank, Canadian International Development Agency, European Commission, National Commission on the Role of Filipino Women, United Nations Children's Fund, United Nations Development Fund for Women and United Nations Population Fund (2008) 'Paradox and Promise in the Philippines: A Joint Country Gender Assessment'.

Baden, S. and C. Pionettia (2011) 'Women's Collective Action in Agricultural Markets: Synthesis of preliminary findings from Ethiopia, Mali and Tanzania', Oxfam GB, available at http://policy-practice.oxfam.org.uk/publications/womens-collective-action-in-agricultural-marketssynthesis-of-preliminary-findi-245931 (accessed 28 November 2012).

Baumann, P. (2000) 'Equity and Efficiency in Contract Farming Schemes: The Experience of Agricultural Tree Crops', ODI Working Paper 139, October 2000. http://www.odi.org.uk/resources/docs/2730.pdf

Behrman, J., R. Meinzen-Dick, and A. Quisumbing (2011) 'The Gender Implications of LargeScale Land Deals', IFPRI Discussion Paper 01056, International Food Policy Research Institute (IFPRI).

Berdegué, J.A. and G. Escobar (2002) 'Rural Diversity, Agricultural Innovation Policies and Poverty Reduction', AgREN Network Paper 122, ODI, London, UK.

Berry, A.R. and W.R. Cline (1979) Agrarian Structure and Productivity in Developing Countries, Baltimore and London: Johns Hopkins University Press.

Bezemer, D., and D.D. Headey (2008) 'Agriculture, development, and urban bias', World Development 34, 1342-1364. 
Bugri, J., and R. King (forthcoming) 'Gender Dimensions of Agricultural Investments: Case studies from Ghana', IIED, London.

Byres, T.J. (2004) 'Neo-classical neo-populism 25 years on: déjà vu and déjà passé. Towards a critique', 4(1-2) Journal of Agrarian Change, 17-44.

Cariño, J. (2005) 'Indigenous Peoples' Right to Free, Prior, Informed Consent: Reflections on Concepts and Practice', talk delivered at the AALS Annual Conference, available at http://www.ajicl.org/AJICL2005/vol221/Carino\%20Formatted.pdf.

CEMIRIDE (Centre for Minority Rights Development) and Minority Rights Group International on behalf of Endorois Welfare Council v. Kenya, African Commission on Human and Peoples' Rights, Communication No. 276/2003.

Chan, M-K. (2010) 'Improving Opportunities for Women in Smallholder-Based Supply Chains: Business case and practical guidance for international food companies', prepared for the Bill \& Melinda Gates Foundation.

Chan, M-K. (2011) 'Review of Value Chain Analyses in the Commodities and Horticulture Sectors: Roles, constraints and opportunities for informal workers', prepared for Women in Informal Employment: Globalizing and Organizing (WIEGO).

Chang, H.J. (2009) 'Rethinking public policy in agriculture: lessons from history, distant and recent', Journal of Peasant Studies, 36:3, July 2009, pp.477-515.

Chauveau, J.-P. (2004) 'Rural Land Plans: Establishing relevant systems for identifying and recording customary rights', London, IIED. http://www.iied.org/pubs/display.php?o=9297IIED

Cheyns, E. and S. Rafflegeau (2007) 'Family agriculture and the sustainable development issue: possible approaches from the African oil palm sector. The example of Ivory Coast and Cameroon', OCL 12(2).

Chmielewska, D. and D. Souza (2010) 'Market Alternatives for Smallholder Farmers in Food Security Initiatives: Lessons from the Brazilian Food Acquisition Programme', Working Paper Number 64, International Policy Centre for Inclusive Growth, United Nations Development Programme.

Co, R.R. (2008) 'Free, Prior and Informed Consent (FPIC): Does it give indigenous peoples more control over development of their lands in the Philippines?'.

http://dspace.mit.edu/handle/1721.1/44353

Colchester, M., N. Jiwan, Andiko, M. Sirait, A.Y. Firdaus, A. Surambo, and H. Pane (2006)

'Promised Land: Palm Oil and Land Acquisition in Indonesia - Implications for Local Communities and Indigenous Peoples', Moreton-in-Marsh, Forest Peoples Programme, Perkumpulan Sawit Watch, HuMA, and the World Agroforestry Centre.

Collier, P. (2008) 'The politics of hunger. How illusion and greed fan the food crisis', 87 Foreign Affairs, 67-79.

Comité Technique Foncier et Développement (2010) 'Les Appropriations de Terres à Grande Echelle: Analyse du Phénomène et Propositions d'Orientations', Paris, MAEE/AFD. http://www.foncier-developpement.fr/wp-content/uploads/appropriation_finale1.pdf

Committee on World Food Security (2011) 'Policy Roundtable on Increasing Food Security through Smallholder-Sensitive Investment in Agriculture', CFS, Thirty-seventh Session, Rome, 17-20 October 2011. http://www.fao.org/docrep/meeting/023/mc066E.pdf 
Cooperatives Council of Australia (1998) 'Australians Extending their own Business.

Submission to the Review of Business Taxation'.

http://www.rbt.treasury.gov.au/submissions/subsdownload/sub056.pdf

Corpuz, J.T. (2010) 'Indigenous Perspectives on FPIC', presentation made at the Second Regional Consultation between Indigenous Peoples Organizations from Asia and the Pacific and the UN-REDD Programme: Free, Prior and Informed Consent Processes and Recourse Mechanisms, 16-18 July 2010, Hanoi, Viet Nam. Available at http://vietnamredd.org/Upload/CMS/Content/News\%20and\%20Events/2nd\%20Regional\%20FPIC\%20WS/4. \%20Indigenous\%20Perspectives\%20on\%20FPIC.pdf.

Cotula, L. (2008) 'International Law and Negotiating Power in Foreign Investment Projects: Comparing Property Rights Protection under Human Rights and Investment Law in Africa', 33 South African Yearbook of International Law 62-111.

Cotula, L. (2011) 'Land Deals in Africa - What is in the Contracts?', London, International Institute for Environment and Development (IIED). http://pubs.iied.org/12568/IED.html

Cotula, L. (2012) Human Rights, Natural Resource and Investment Law in a Globalised World: Shades of Grey in the Shadow of the Law, London and New York, Routledge.

Cotula, L., S. Vermeulen, R. Leonard, and J. Keeley (2009) 'Land Grab or Development Opportunity? Agricultural Investment and International Land Deals in Africa', Rome/London, Food and Agriculture Organization of the UN (FAO)/International Fund for Agricultural Development (IFAD)/International Institute for Environment and Development (IIED). http://www.iied.org/pubs/display.php?o=12561IIED

Daley, E. (2011) 'Gendered Impacts of Commercial Pressures on Land', International Land Coalition.

De Schutter, O. (2009) 'Report of the Special Rapporteur on the Right to Food - Addendum, "Large-Scale Land Acquisitions and Leases: A Set of Minimum Principles and Measures to Address the Human Rights Challenge"', 28 December 2009, UN Doc. A/HRC//13/33/Add.2.

Deininger, K. (2003) 'Land Policies for Growth and Poverty Reduction', Washington DC, World Bank.

Deininger, K. and D. Byerlee, D. (2012) 'The rise of large farms in land abundant countries: do they have a future?', 40(4) World Development 701-714.

Deininger, K. and D. Byerlee, with J. Lindsay, A. Norton, H. Selod, and M. Stickler (2011)

'Rising Global Interest in Farmland: Can it Yield Sustainable and Equitable Benefits?', Washington DC, World Bank.

http://econ.worldbank.org/external/default/main?pagePK=64165259\&theSitePK=469382\&piPK= 64165421\&menuPK=64166322\&entityID=000334955_20110208033706

Develtere, P., I. Pollet, and F.O. Wanyama (2008) 'Cooperating Out of Poverty. The renaissance of the African cooperative movement', Geneva: International Labour Organization http://www.oit.org/public/english/employment/ent/coop/africa/download/coop_out_of_poverty.pdf

DFID (2001) 'Competition Policy, Law and Developing Countries', Background Briefing,

September 2001. Available at:

http://webarchive.nationalarchives.gov.uk/+/http:/www.dfid.gov.uk/Documents/publications/itdco mpetitionbrief.pdf

Djiré, M. (2007) 'Land Registration in Mali - No land ownership for farmers? Observations from peri-urban Bamako', London, IIED, Drylands Issue Paper No. 144.

http://www.iied.org/pubs/display.php?o=12538IIED 
Djiré, M., with A. Diawara and A. Keita (forthcoming) 'Agricultural Investment in Mali: Context, Trends and Case Studies', IIED, London.

Djurfeldt, G., E. Aryeetey, and A. Isinika (2000) 'African Smallholders: Food Crops, Markets and Policy', CABI. http://bookshop.cabi.org/?page=2633\&pid=2221\&site=191

Dorward, A., S. Anderson, and Y. Nava, J. Pattison, R. Paz, J. Rushton, and E. Sanchez Vera (2009) 'Hanging in, stepping up and stepping out: livelihood aspirations and strategies of the poor', Development in Practice, 19 (2). pp.240-247.

Dürr, J., M. Zander, and S. Rosales (2010) 'Cadenas productivas, dinámicas agrarias y cuentas territoriales de base agropecuaria: el sur de Petén', Guatemala: Instituto de estudios agrarios y rurales.

Dyer, G. (1998) 'Farm size and productivity. A new look at the old debate revisited', 33(26) Economic and Political Weekly Review of Agriculture A113-A116.

Eaton, C. and A. Shepherd (2001) 'Contract Farming: Partnerships for Growth', Rome, Food and Agriculture Organization of the UN, Agricultural Services Bulletin 145.

Farmer Focus (2010) 'Qualitative Farmer Research Overview', presentation to Gates Foundation Advisory Panel, 25-26 January 2010.

Farquhar, I. (2011) 'Competition Law and the New Slavery'.

http://www.makefruitfair.org.uk/sites/default/files/competition_law_and_slavery_from_blnationalc oordinatorpc.pdf

Federico, G. (2005) Feeding the World: An Economic History of Agriculture, 1800-2000, Princeton and Oxford: Princeton University Press.

Food and Agriculture Organization (2007a) 'Gender and Food Security: Facts and Figures', FAO, Rome.

Food and Agriculture Organization (2007b) 'Gender and Law: Women's Rights in Agriculture', FAO Legislative Study 76, Revision 1.

Food and Agriculture Organization (2010) 'Technical Compendium: Description of Agricultural Trade Policies in Peru, Tanzania and Thailand', Environment and Natural Resources Management Working Paper No. 36, Bioenergy and Food Security Project, FAO, Rome.

Ghana Statistical Service (2008) 'Ghana Living Standard Survey: Report of the fifth round (GLSS 5)', as cited in: FAO (2012) 'Gender Inequalities in Rural Employment in Ghana: An Overview', draft version, March 2012.

Görgen, M., B. Rudloff, J. Simons, A. Üllenberg, S. Väth, and L. Wimmer (2009) 'Foreign Direct Investment (FDI) in Land in Developing Countries', Eschborn, Deutsche Gesellschaft für Technische Zusammenarbeit (GTZ).

http://www2.gtz.de/urbanet/library/detail1.asp?number=7529

Griffin, K. (1979) The Political Economy of Agrarian Change, 2nd Edition, London, Macmillan.

Grobakken, I.A. (2005) 'Land Reform, Poverty and Empowerment of Women in Guatemala', master's thesis in political science, Department of Political Science, University of Oslo.

Gauster, S. and J. Ozaeta (2011) 'Producción de cultivos de exportación no tradicional en Chichoy Alto: el rol de las mujeres', Guatemala: Instituto de estudios agrarios y rurales. 
Haggblade, S. (2011) 'Modernizing African agribusiness: reflections for the future', Journal of Agribusiness in Developing and Emerging Economies, Vol. 1:1 10-30.

Haile, M., W. Witten, K. Abraha, S. Flssha, A. Kebede, G. Kassa, and G. Reda (2005) 'Land Registration in Tigray, Northern Ethiopia', London, IIED.

Hazell P., C. Poulton, S. Wiggins, and A. Dorward (2010) 'The future of small farms: trajectories and policy priorities', World Development 38(10): 1349-1361.

Hellin, J., M. Lundy, and M. Meijer (2009) 'Farmer organization, collective action and market access in Meso-America', Food Policy 34 (1), 16-22.

Henson, S. and J. Humphrey (2009) 'The Impacts of Private Food Safety Standards on the Food Chain and on Public Standard-Setting Processes', paper prepared for FAO/WHO, May 2009. www.fao.org/docrep/012/i1132e/i1132e00.pdf

Huang, J., X. Wang, and H. Qiu (2012) 'Small-scale Farmers in China in the Face of Modernisation and Globalisation,' publication of the Knowledge Programme Small Producer Agency in the Globalised Market, IIED and Hivos. https://www.hivos.nl/dut../content/download/80109/693792/file/china\%20paper.pdf

Human Rights Watch (2012a) "Waiting Here for Death": Forced Displacement and "Villagization" in Ethiopia's Gambella Region'.

http://www.hrw.org/sites/default/files/reports/ethiopia0112webwcover_0.pdf

Human Rights Watch (2012b" 'What Will Happen if Hunger Comes?": Abuses against the Indigenous Peoples of Ethiopia's Lower Omo Valley'.

http://www.hrw.org/sites/default/files/reports/ethiopia0612webwcover.pdf

Inter-American Court of Human Rights (2001) Mayagna (Sumo) Awas Tingni Community v. Nicaragua, Judgement, 31 August 2001.

http://www1.umn.edu/humanrts/iachr/AwasTingnicase.html

Inter-American Court on Human Rights (2007) Saramaka People v. Suriname, Judgement, 28 November 2007.

www.forestpeoples.org/.../suriname_iachr_saramaka_judgment_nov07_eng.pdf

International Co-operative Alliance (2001) 'Survey on agricultural cooperatives in Kenya'. Quoted in: Majurin, E. (2010) 'Promising Practices: How co-operatives work for working women in Africa', International Labour Organization.

International Fund for Agricultural Development (2010) 'Study Report of the International Fund for Agricultural Development on Gender and Youth in the Tea and Coffee Value Chains', IFAD Report No. 2295-RW.

International Trade Centre (ITC) and the Economic Community of West African States (ECOWAS) (2011) 'Strategic Orientation Document for Mango Value Chain in the Economic Community of West African States (ECOWAS)'.

Jayne, T.S., T. Yamano, M. Weber, D. Tschirley, R. Benfica, D. Neven, A. Chapoto, and B. Zulu (2002) 'Smallholder Income and Land Distribution in Africa: Implications for Poverty Reduction Strategies'. Selected Paper presented at the Annual Meeting of the American Agricultural Economics Association Long Beach, California, 28-31 July 2002.

Jayne, T.S., with S. Haggblade, N. Minot, and S. Rashid (2011) 'Agricultural Commercialization, Rural Transformation and Poverty Reduction: What Have We Learned about How to Achieve This?'. Synthesis report prepared for the African Agricultural Markets 
Programme Policy Symposium, Alliance for Commodity Trade in Eastern and Southern Africa, 20-22 April 2011, Kigali, Rwanda.

Koenig T., J. Blatt., K. Brakel, K. Kloss, T. Nilges, and F. Woellert (2008) 'Market-Driven Development and Poverty Reduction: A value chain analysis of fresh vegetables in Kenya and Tanzania', Humbolt University Seminar für Ländliche Entwicklung. http://edoc.huberlin.de/series/sle/228/PDF/228.pdf

Knight, R. (2011) 'Statutory Recognition of Customary Land Rights in Africa: An Investigation into Best Practices for Law-Making and Implementation', Rome, Food and Agriculture Organization of the UN (FAO), Legislative Study No. 105. http://www.fao.org/docrep/013/i1945e/i1945e00.htm

Lahiff, E., N. Davis, and T. Manenzhe (2012) 'Joint Ventures in Agriculture: Lessons from Land Reform Projects in South Africa', London, International Institute for Environment and Development, available at http://pubs.iied.org/12569IIED.html

Lastarria-Cornhiel, S. (2008) 'Feminisation of Agriculture: trends and driving forces', background paper for the World Development Report 2008

Le Meur, P.-Y. (2006) 'Governing land, translating rights. The rural land plan in Benin', in Mosse, D. and D. Lewis (eds) Development Brokers and Translators: The Ethnography of Aid and Agencies, Bloomfield, USA, Kumarian Press.

Lipton, M. (1977) Why Poor People Stay Poor. A Study of Urban Bias in World Development, London, Temple Smith.

Lipton, M. (2010) Land Reform in Developing Countries: Property Rights and Property Wrongs, London and New York, Routledge.

Little, P.D. and M.J. Watts (eds) (1994) Living under Contract: Contract Farming and Agrarian Transformation in Sub-Saharan Africa, Madison, University of Wisconsin Press.

Lowder, S.K. and B. Carisma (2011) 'Financial Resource Flows to Agriculture: A review of data on government spending, official development assistance and foreign direct investment', ESA Working Paper No. 11, 19 December 2011, Agricultural Development Economics Division, Food and Agriculture Organization of the United Nations.

http://www.fao.org/docrep/015/an108e/an108e00.pdf

Maertens, M. and J.F.M. Swinnen (2009) 'Trade, standards, and poverty: evidence from Senegal', 37(1) World Development 161-178

Majid Cooke, F., S.M. Toh, and J. Vaz (2011) 'Community-Investor Business Models: Lessons from the oil palm sector in East Malaysia', London, IIED. http://pubs.iied.org/12570IIED.html

Makhathini, M. (2010), 'Mondi's "Sale and Leaseback" Model in South Africa', in Cotula, L. and R. Leonard (eds) Alternatives to Land Acquisitions: Agricultural Investment and Collaborative Business Models, London/Bern/Rome/Maputo, International Institute for Environment and Development/Swiss Agency for Development and Cooperation/International Fund for Agricultural Development/Centro Terra Viva, pp. 9-32.

Makutsa, P. (2010) 'Land Grab in Kenya: Implications for Smallholder Farmers', Nairobi: Eastern Africa Farmers' Federation.

http://www.sfoap.net/fileadmin/user_upload/sfoap/KB/docs/Report\%20of\%20Land\%20Grab\%20 in\%20Kenya.pdf

Mason, N.M. and R.J. Myers (2011) 'The Effects of the Food Reserve Agency on Maize Market Prices in Zambia'. Available at: http://www.aec.msu.edu/fs2/zambia/ps_50.pdf 
Mather, D. and T.S. Jayne (2011) 'The Impact of State Marketing Board Operations on Smallholder Behavior and Incomes: The Case of Kenya', MSU International Development Working Paper No. 119. Available at:

http://ageconsearch.umn.edu/bitstream/120742/2/idwp119.pdf

Mercopress (2011) 'Brazilian president promises land reform and distribution for family settlers', 12 May 2011. http://en.mercopress.com/2011/05/12/brazilian-president-promises-landreform-and-distribution-for-family-settlers

Monnereau, I. and B. Helmsing (2011) 'Local embedding and economic crisis: comparing lobster chains in Belize, Jamaica and Nicaragua', in A.J.H. (Bert) Helmsing and Sietze Vellema (eds) Value Chains, Inclusion and Endogenous Development Contrasting Theories and Realities, Routledge.

Mujenja, F., and C. Wonani (forthcoming) 'Long-Term Outcomes of Agricultural Investments: Lessons from Zambia', London, International Institute for Environment and Development.

Nguiffo, S. and B. Schwartz (2012) 'Herakles' 13th Labour? A Study of SGSOC's Land Concession in South-West Cameroon', Yanoudé, Centre pour l'Environnement et le Développement/RELUFA. http://www.forestpeoples.org/topics/palm-oilrspo/publication/2012/ced-publication-herakles-13th-labour-study-sgsoc-s-land-conces

Nhantumbo, I. and A. Salomão (2010) 'Biofuels, Land Access and Rural Livelihoods in Mozambique', London, IIED. http://pubs.iied.org/12563IIED.html

Nganwa, P., P.M. Lyne, and S. Ferrer (2010). 'What will South Africa's new Cooperatives Act do for small producers? An analysis of three case studies in KwaZulu-Natal', Agrekon 49(1), 39-55

Norfolk, S. and C. Tanner (2007) 'Improving Security for the Rural Poor: Mozambique Country Case Study', Rome: Food and Agriculture Organization of the UN, FAO LEP Working Paper No. 5, available at ftp://ftp.fao.org/sd/SDA/SDAR/sard/Mozambiquecase.pdf

Oakland Institute (2010) '(Mis)Investment in Agriculture: The Role of the International Finance Corporation in the Global Land Grab', Oakland, Oakland Institute. http://www.oaklandinstitute.org/node/2622

Oakland Institute (2011a) 'Understanding Land Investment Deals in Africa - Country Report: Mozambique', Oakland, Oakland Institute. http://media.oaklandinstitute.org/specialinvestigation-understanding-land-investment-deals-africa

Oakland Institute (2011b) 'Understanding Land Investment Deals in Africa - Country Report: Tanzania', Oakland, Oakland Institute. http://media.oaklandinstitute.org/special-investigationunderstanding-land-investment-deals-africa

Oakland Institute (2011c) 'Understanding Land Investment Deals in Africa - Country Report: Mali', Oakland, Oakland Institute. http://media.oaklandinstitute.org/special-investigationunderstanding-land-investment-deals-africa

Oakland Institute (2011d) 'Understanding Land Investment Deals in Africa - Country Report: Ethiopia', Oakland, Oakland Institute. http://media.oaklandinstitute.org/special-investigationunderstanding-land-investment-deals-africa

Observatorio Ambiental (2011). 'Dinámicas agrarias y rurales en la Guatemala del siglo XXI'. Available at http://www.oag.org.gt

Orden, D., M. Torero, and A. Gulati (2004)) 'Agricultural Markets and the Rural Poor', background paper for workshop of the Poverty Reduction Network (POVNET), 5 March 2004. 
http://dfid-agriculture-

consultation.nri.org/theme4/keypapers/povnet_agricultural_markets_and_the_rural_poor.pdf

Oxfam (2011) 'Land and Power: The Growing Scandal Surrounding the New Wave of Investments in Land', Oxford, Oxfam. http://www.oxfam.org/sites/www.oxfam.org/files/bp151. land-power-rights-acquisitions-220911-en.pdf

Oxfam (2012) 'Our Land, Our Lives: Time out on the global land rush'. http://policypractice.oxfam.org.uk/publications/our-land-our-lives-time-out-on-the-global-land-rush-246731

Penrose-Buckley, C. (2007) Producer Organisations: A Guide to Developing Collective Rural Enterprises, Oxfam Publishing.

Porto G., N.D. Chauvin, and M. Olarreaga (2011) 'Supply Chains in Export Agriculture, Competition, and Poverty in Sub-Saharan Africa', Washington DC: World Bank. http://siteresources.worldbank.org/INTRANETTRADE/Resources/Supply_Chains.pdf

Potts, J., J. van der Meer and J. Daitchman (2010) The State of Sustainability Initiatives Review 2010: Sustainability and Transparency, IIED and IIED,

http://www.iisd.org/publications/pub.aspx?pno=1363

Reardon, T., C. Barrett, J.A. Berdegué, and J.F.M. Swinnen (2009) 'Agri-food industry transformation and small farmers in developing countries', 37(11) World Development 1717-1727.

Robbins, P. (2011) 'Commodity Exchanges and Smallholders in Africa', New Business Models for Sustainable Trading Relationships project, IIED and Sustainable Food Lab. http://pubs.iied.org/16028IIED.html

Santos, J.M. (2010) 'Safeguarding Fair Competition: Considerations for Crafting a Responsive Philippine Antitrust Policy', Small Enterprises Research and Development Foundation. www.serdef.org and http://xa.yimg.com/kq/groups/19588445/1764359715/name/SAFEGUARDING

Schoneveld, G.C., L.A. German, and E. Nutakor (2011) 'Land-based investments for rural development? A grounded analysis of the local impacts of biofuel feedstock plantations in Ghana', 16(4) Ecology and Society 10.

Shepherd. A.W. (2005) 'The Implications of Supermarket Development for Horticultural Farmers and Traditional Marketing Systems in Asia', paper first presented to the FAO/AFMA/FAMA Regional Workshop on the Growth of Supermarkets as Retailers of Fresh Produce, Kuala Lumpur, 4-7 October 2004. http://valuechains4poor.org/file/asia_supermarkets.pdf

Seidler, E. (2001) 'Wholesale Market Development - FAO's Experience', paper prepared for the 22nd Congress of the World Union of Wholesale Markets, Durban, South Africa, September 2001. FAO: Rome.

Skinner, J. and L. Cotula (2011) 'Are Land Deals Driving “Water Grabs”?', London, IIED. http://pubs.iied.org/17102IIED.html

Social Institutions and Gender Index (SIGI) (2012a) 'Gender Equality and Social Institutions in Guatemala'. Available at http://genderindex.org/country/guatemala, accessed 15 September 2012

Social Institutions and Gender Index (SIGI) (2012b) 'Gender Equality and Social institutions in Nigeria'. Available at http://genderindex.org/country/nigeria, accessed 15 September 2012 
Social Institutions and Gender Index (SIGI) (2012c) 'Gender Equality and Social Institutions in Philippines'. Available at http://genderindex.org/country/philippines, accessed 15 September 2012

Social Institutions and Gender Index (SIGI) (2012d) 'Gender Equality and Social Institutions in Tanzania'. Available at http://genderindex.org/country/tanzania, accessed 15 September 2012

Songwe, V. and K. Deininger (2009) 'Foreign Investment in Agricultural Production: Opportunities and Challenges', World Bank. http://siteresources.worldbank.org/INTARD/Resources/3358071229025334908/ARDNote45a.pdf

Sulle, E. and F. Nelson (2009) 'Biofuels, Land Access and Rural Livelihoods in Tanzania', London, IIED. www.iied.org/pubs/pdfs/12560lIED.pdf

Teyssier, A. (2010) ‘Décentraliser la Gestion Foncière? L'expérience de Madagascar', Paris, CIRAD, Perspectives,

www.cirad.fr/content/.../4/.../Persp04_Teyssier_foncier_madagascar_fr.pdf

Tienhaara, K. (2012) 'The potential perils of forest carbon contracts for developing countries: cases from Africa', 39(2) Journal of Peasant Studies 551-572.

Tiffen, M. and M. Mortimore (1990) Theory and Practice in Plantation Agriculture: An Economic Review, London, ODI.

TNRF (2012) 'Understanding Land and Investments in Tanzania', Arusha, Tanzania Natural Resource Forum.

Torero, M. (2011) 'A Framework for Linking Small Farmers to Markets', paper presented at the IFAD Conference on New Directions for Smallholder Agriculture, 24-25 January 2011.

Tschirley, D., M. Ayieko, M. Hichaambwa, J. Goeb, and W. Loescher (2010) 'Modernizing Africa's Fresh Produce Supply Chains without Rapid Supermarket Takeover: Towards a Definition of Research and Investment Priorities', MSU International Development Working Paper 106, June 2010. Michigan State University.

UNAIDS (2008) 'HIV, Gender and Food Security. Gender and HIV/AIDS Factsheet No 14'. Quoted in Mehra, R. and M. Hill Rojas, Women, Food Security and Agriculture in a Global Market Place, International Center for Research on Women.

UNCTAD (2007) 'Challenges and Opportunities Arising from Private Standards on Food Safety and Environment for Exporters of Fresh Fruit and Vegetables in Asia: Experiences of Malaysia, Thailand and Viet Nam'.

UNCTAD (2012) World Investment Report 2012: Towards a New Generation of Investment Policies, Geneva, United Nations Conference on Trade and Development.

UNCTAD/Swiss Futures and Options Association (2006) 'The World's Commodity Exchanges past-present-future'.

UNIDO (2011) 'Tanzania's Cashew Value Chain: A diagnostic', United Nations Industrial Development Organization (UNIDO), Vienna.

Vermeulen, S. and L. Cotula (2010) 'Making the Most of Agricultural Investment: A survey of business models that provide opportunities for smallholders', Rome/London/Bern,

FAO/IFAD/IIED/SDC. http://www.iied.org/pubs/display.php?o=12566IIED 
Vorley, B. (2002) 'Sustaining Agriculture: Policy, Governance, and the Future of Family-based Farming'. A Synthesis of the Collaborative Research Project 'Policies that Work for Sustainable Agriculture and Regenerating Rural Livelihoods', IIED, London.

Vorley, B., M. Lundy, and J. MacGregor (2009) 'Business models that are inclusive of small farmers', Chapter 6 in Carlos A. da Silva et al. (eds) Agro-Industries for Development, FAO, UNIDO, IFAD, and CAB International.

Vorley, B., del Pozo-Vergnes, E., Barnett, A. (2012) Small producer agency in the globalised market: Making choices in a changing world. IIED, London; HIVOS, The Hague.

Wiggins, S., J. Kirsten, and L. Llambí (2010) 'The future of small farms', 38(10) World Development 1341-1348.

Williams, T. (2009) 'An African Success Story: Ghana's Cocoa Marketing System'. Available at: http://www2.ids.ac.uk/gdr/cfs/pdfs/Wp318.pdf

Wonani, C., W. Mbuta and A. Mkandawire (2012) 'Gender and Equity Implications of LandRelated Investments on Labour and Income Generating Opportunities: Zambia Country Study', draft report June 2012.

World Bank, Food and Agriculture Organization (FAO) of the United Nations, and International Fund for Agricultural Development (IFAD) (2009) Gender in Agriculture Sourcebook, Washington, DC: World Bank.

World Economic Forum (2012) 'WEF New Vision for Agriculture'. http://www.weforum.org/issues/agriculture-and-food-security 


\section{NOTES}

1 Tanzania country study.

${ }^{2}$ Eighty per cent of hungry people live in rural areas, and most work as small-scale producers. R. Bailey (2011) 'Growing a Better Future: Food justice in a resource-constrained world', Oxfam, p.56. http://www.oxfam.org/sites/www.oxfam.org/files/growing-a-better-future-010611-en.pdf

${ }^{3} \mathrm{FAO}$ (2009) 'How to Feed the World in 2050'. http://www.fao.org/wsfs/forum2050/wsfs-backgrounddocuments/hlef-issues-briefs/en. Further, smallholder production has been shown to be economically more efficient than plantations operated by wage labour. Smallholder production has a massive employment effect that is not seen in the case of large mechanized farming. Songwe and Deininger (2009).

${ }^{4}$ http://www.nepad.org/nepad/knowledge/doc/1787/maputo-declaration

${ }^{5}$ Cotula et al. (2009); Deininger et al. (2011); Oxfam (2011); Anseeuw et al. (2012).

${ }^{6}$ Between 2001 and 2010, 203 million hectares were reported to be under consideration or negotiation worldwide. Anseeuw et al. (2011).

${ }^{7}$ Cotula et al. (2009); Sulle and Nelson (2009); Nhantumbo and Salomão (2010); Comité Technique Foncier et Développement (2010); Oakland Institute (2011a, b, c, and d); Oxfam (2011); Deininger et al. (2011); Anseeuw et al. (2012).

${ }^{8}$ AP (2012) 'Honduran land seizures raise fear of wider clashes of class and ideology', The Guardian, 15 July 2012. http://www.guardian.co.uk/world/2012/jul/15/honduras-land-seizures-la-confianza

${ }^{9}$ Ibid.

${ }^{10}$ Human Rights Watch, 2012a and b.

${ }^{11}$ Sulle and Nelson (2009 and forthcoming); Nhantumbo and Salomão (2010); Bugri and King (forthcoming).

${ }^{12}$ Cotula (2011); Tienhaara (2012); Nguiffo and Schwartz (2012); Djiré et al. (forthcoming).

${ }^{13}$ Cotula (2011); Skinner and Cotula (2011); Djiré et al. (forthcoming).

${ }^{14}$ Colchester et al., (2006); Oxfam, (2011).

${ }^{15}$ Anseeuw et al. (2012). See also Makutsa (2010).

${ }^{16}$ Growth originating in agriculture, in particular the smallholder sector, is at least twice as effective in benefiting the poorest people as growth from non-agricultural sectors. FAO (2010) 'How to Feed the World', op. cit., p.2. See also Chang (2009).

${ }^{17}$ Lipton (1977); Berry and Cline (1979); Dyer (1998); Byres (2004); Collier (2008).

${ }^{18}$ http://www.fao.org/docrep/013/i2050e/i2050e00.htm

${ }^{19}$ Guatemala case study report.

${ }^{20}$ Nigeria case study report.

${ }^{21}$ See, for example, Baden and Pionetti (2011).

${ }^{22}$ Personal communication, Celeste Molina, Oxfam Great Britain.

${ }^{23}$ Behrman et al. (2011); Daley (2011); Bugri and King (forthcoming); Wonani et al. (2012).

${ }^{24}$ Farmer Focus initiative for Bill \& Melinda Gates Foundation.

25 'Rights-based versus Market-based Development: A false dichotomy for small-scale farmers?', report of Provocation Seminar Series, Stockholm, 3 March 2011. http://www.iied.org/provocation-seminarseries-rights-based-versus-market-based-development

${ }^{26}$ Segeplan (2012) 'Orientaciones estratégicas de política 2012-2014'.

${ }^{27}$ Guatemala country study.

${ }^{28}$ Cotula et al. (2009); Görgen et al. (2009); Oakland Institute (2011); Djiré et al. (forthcoming).

${ }^{29}$ Rural 21, 'How Brazilian agricultural policy is promoting family farms'. http://www.rural21.com/uploads/media/rural_2011_4_36-39_01.pdf

${ }^{30}$ See, for example, the Policy Framework for Investment developed by the OECD. http://www.oecd.org/investment/investmentpolicy/36671400.pdf.

${ }^{31}$ Oakland Institute (2010).

${ }^{32}$ At p.45. The Investment Blueprint is available at http://www.sagcot.com/uploads/media/Invest-BlueprintSAGCOT_High_res.pdf. 
${ }^{33}$ A good database of relevant legislation can be found at http://ppp.worldbank.org/public-privatepartnership/legislation-regulation/laws.

${ }^{34}$ For more information see, Oxfam (2009) 'The Missing Middle in Agricultural Finance', and Dalberg (2012) 'Catalysing smallholder agricultural finance'.

${ }^{35}$ Guatemala case study report.

${ }^{36}$ Nigerian case study report.

${ }^{37}$ Personal communication., Ana Iris Martinez Diaz, Oxfam America

${ }^{38}$ For example, Baden and Pionetti (2011).

${ }^{39}$ Guatemala case study report.

40 Tanzania case study report

${ }^{41}$ http://policy-practice.oxfam.org.uk/our-work/food-livelihoods/gem

${ }^{42}$ Guatemala case study report.

43 'Innovating to Compete: Small holder farmers' agency and markets in East Africa', report by the Eastern African members of the Learning Network, 'Small Producer Agency in the Globalized Market', convened by IIED. Hivos and Mainumby.

${ }^{44}$ Articles $44-46$ of the law.

${ }^{45}$ Article 9 of the Law on Investment of the Kingdom of Cambodia, Article 6 of Guatemala's Foreign Investment Act of 1998, and Article 22 of the Tanzania Investment Act of 1997.

${ }^{46}$ These laws are available at: http://www.rree.gob.pe/portal/economia2.nsf/0/a0e3d3d20c0a35d005256c0d005976c0?OpenDocumen t

${ }^{47}$ See, for example, Article 23 of the Tanzania Investment Act of 1997, and also Article 11 of Guatemala's Foreign Investment Act of 1998.

${ }^{48} \mathrm{http}: / /$ unctad.org/Sections/dite_pcbb/docs/bits_tanzania.pdf

49 http://unctad.org/Sections/dite_pcbb/docs/dtt_Tanzania.PDF

${ }^{50}$ For example, under Mali's Investment Code 1991, as amended in 2005; Mozambique's Investment Act 1993; and the Nigerian Investment Promotion Commission Act 1995.

51 Article 2.

52 Article 21 of the Investment Act of 1993.

${ }^{53}$ Article 6 of Decree No. 14/93 of 1993, as amended by Decree No. 36/95 of 1995.

${ }^{54}$ Cotula (2011); Skinner and Cotula (2012); Djiré (forthcoming).

55 In 'willing seller, willing buyer' land reform programmes, redistributed land is voluntarily sold at market prices by landowners to government agencies or directly to reform beneficiaries receiving government grants.

${ }^{56}$ According to a speech by the President of Brazil, Dilma Rousseff, a million people have received plots through the agrarian reform over a period of 40 years, 614,000 of them within the past decade (quoted by Mercopress 2011).

${ }^{57}$ See Gerson Teixeira (Brazilian Association for Land Reform) at: http://www.mst.org.br/Gerson-Teixeiraagravamento-da-concentracao-das-terras

${ }^{58}$ Article 3.

${ }^{59}$ Articles 43-48 of the Land Code of 2000-02.

${ }^{60}$ Articles 12(a) and (b), 13(2), and 14(2) of the Land Act of 1997.

${ }^{61}$ Article 18 of the Village Land Act of 1999.

62 Article 237 of the Constitution of 1995, and Sections 2 and 3 of the Land Act of 1998.

${ }^{63}$ Article 18 of Tanzania's Village Land Act of 1999 and Article 12 of Mozambique's Land Act of 1997. See Knight (2011).

${ }^{64}$ Adenew and Abdi (2005) and Haile et al. (2005) respectively.

${ }^{65}$ Under Niger's Rural Code and its implementing regulations.

${ }^{66}$ Under Mali's Pastoral Charter of 2001.

${ }^{67}$ Article 13(3) of the Land Act of 1997. 
${ }^{68}$ Article 12. The Guidelines are available at http://www.fao.org/fileadmin/user_upload/newsroom/docs/VG_en_Final_March_2012.pdf.

${ }^{69}$ Article 12.6.

${ }^{70}$ Roundtable on Sustainable Biofuels (RSB), 'Use of Terms'. http://rsb.epfl.ch/files/content/sites/rsb2/files/Biofuels/Certification/RSB\%20EU\%20RED\%20Standards/ RSB-DOC-11-001-01-001_RSB_EU_RED_Use_of_terms.pdf

${ }^{71}$ From Oxfam Australia (2010) 'Guide to Free, Prior and Informed Consent'. http://www.culturalsurvival.org/files/guidetofreepriorinformedconsent_0.pdf

72 See, for example, Criterion 12.b of the Roundtable on Sustainable Biofuels, a third-party certification system for biofuels sustainability standards.

${ }^{73}$ Norfolk and Tanner (2007); Nhantumbo and Salomão (2010); Oakland Institute (2011a).

${ }^{74}$ Articles 7(c) and 59.

${ }^{75}$ Article 3(g).

${ }^{76}$ Article 56

77 Co (2008); Cariño (2005); Corpuz (2010).

${ }^{78}$ Testimonies of families in Sayaxché, Oxfam research visit, September 2012.

${ }^{79}$ See, for example, the cases Mayagna (Sumo) Awas Tingni Community v. Nicaragua, Maya Indigenous Communities of the Toledo District v. Belize, Sawhoyamaxa Indigenous Community v. Paraguay, and Saramaka People v. Suriname.

${ }^{80}$ CEMIRIDE v. Kenya.

${ }^{81}$ Article 12.6 .

${ }^{82}$ Article 266 of the 1992 Constitution.

83 Section 40 of the Land Act 1998.

${ }^{84}$ Articles 16 and 21 of Law No. 11/022 of 2011.

${ }^{85}$ Agence France Presse (2012) 'Le Cambodge suspend l'attribution de nouvelles concessions', 7 May 2012. http://farmlandgrab.org/post/view/20456. Whether the pause will be used for genuine reforms to support community land tenure is, however, in doubt, as the draft Agricultural Land Law contains provisions to imprison farmers who oppose government-led decisions on land demarcation. Newspapers in Cambodia have reported new land concessions being granted despite the freeze: www.phnompenhpost.com/index.php/2012070557236/National-news/not-all-elc-listed.html

${ }^{86}$ In Mozambique, for example: see Article 16 of the Environment Act of 1997 and Article 26 of the Investment Act of 1993.

87 In Mozambique, Decree No. 45/2004 of 2004, Article 14

${ }^{88}$ See, for example, Schoneveld et al. (2011); Nhantumbo and Salomão (2010); and Oakland Institute (2011a).

${ }^{89}$ Article 12.2.

90 Tiffen and Mortimore (1990). Alternatively, these factors may push investors towards more capitalintensive plantations.

${ }^{91}$ For example, Bezemer and Headey (2008).

92 Unofficial translation.

${ }^{93}$ Oxfam International/Institute of Development Studies, 'Life in a Time of Food Price Volatility', Guatemala case. http://policy-practice.oxfam.org.uk/our-work/food-livelihoods/food-price-volatility-research

${ }^{94}$ Guatemala case study report.

${ }^{95}$ http://www.clarity.coop/

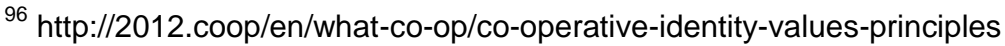

${ }^{97}$ Rural cooperatives let Chinese farmers thrive together. China View 16 December 2009 http://news.xinhuanet.com/english/2009-12/16/content_12658517.htm

${ }^{98} \mathrm{http}: / /$ www.thenews.coop/article/ncdc-amendment-bill-2012-tabled-parliament

99 http://www.esfim.org/collaborative-research/peru

${ }^{100}$ Malini Shankar, presentation to Agriconnect, 2011.

${ }^{101}$ For example, see Seidler (2001). 
102 For example, see Haggblade (2011); Tschirley et al. (2010).

${ }^{103} \mathrm{http}: / /$ www.kilimotrust.org/enhancing-market-support-infrastructure.html

104 http://www.ifad.org/evaluation/public_html/eksyst/doc/prj/r121szbe.html

${ }^{105}$ Accord Associates (2007) 'Opportunities for Sub-Saharan African Small-Farmers to supply the UK Fresh Fruit and Vegetable Markets', unpublished report for IIED, Accord Associates LLP, May 2007.

${ }^{106}$ Cheyns and Rafflegeau (2007). http://www.jle.com/e-docs/00/04/10/66/vers_alt/VersionPDF.pdf

107 At the same time as demise of International Commodity Agreements (ICAs).

${ }^{108}$ For example, see De Schutter (2011).

${ }^{109}$ DFID case study on the Ethiopian Commodity Exchange. Available at: http://www.dfid.gov.uk/stories/case-studies/2011/coffee-and-commodities/

${ }^{110}$ See http://www.odi.org.uk/sites/odi.org.uk/files/odi-assets/publications-opinion-files/5126.pdf for an example of how this has worked in the Colombia coffee sector.

111 http://www.info.gov.za/speech/DynamicAction ?pageid $=461 \&$ sid $=25746 \&$ tid $=59788$

${ }^{112}$ A monopsony exists where only one buyer faces many sellers. As the only purchaser of a good or service, the monopsonist may dictate terms to its suppliers in the same manner that a monopolist controls the market for its buyers

113 'Safeguarding Fair Competition: An Examination of Philippine Antitrust Policy', IDEALS, Inc. http://xa.yimg.com/kq/groups/19588445/1764359715/name/SAFEGUARDING

114 http://www.africacncl.org/Whats_New/downloads/Press_Release-Supplier_Development.pdf

${ }^{115}$ See ActionAid (2010a) on the importance of the UK supermarket ombudsman being able to receive complaints from 'indirect suppliers' i.e. farmers, many of whom can be presumed to be from developing countries.

http://www.actionaid.org.uk/doc_lib/why_large_suppliers_must_have_access_to_the_ombudsman_26-03-10.pdf

116

http://www.regoverningmarkets.org/en/resources/latin_america/innovative_policy_argentina_argentina best_commercial_practicecode_2000_2006_as_an_efficient_policy_inno

${ }^{117}$ WFP Office of Evaluation (2011) 'Mid-Term Evaluation - Notes on Results'.

118

www.regoverningmarkets.org/en/resources/latin_america/innovative_policy_mexico_mexico_strategy_f or_the_inclusion_of_small_and_medium_sized_avocado_producers_

119 Potts et al., (2010).

${ }^{120}$ UNIDO (2009) 'Round Table: Sustainability Standards in International Trade: Hurdles or Opportunities?', briefing note, 9 December 2009.

${ }^{121} \mathrm{http}: / /$ solidaridadnetwork.org/soy-producer-support-initiative

122 Potts et al., (2010)

${ }^{123}$ www.africert.co.ke

${ }^{124}$ The Utz Certified Good Inside Code of Conduct for cocoa specifies that certified producer groups must be 'inclusive to all producers' and that 'women and men receive equal access to training and equal opportunities for promotion'. Fairtrade standards for smallholder POs specify that they are expected to encourage disadvantaged groups to participate actively, with special attention to the participation of female members.

${ }^{125}$ Vorley et al., (2012). 
This research report has been written to share research results, to contribute to public debate and to invite feedback on development and humanitarian policy and practice. It does not necessarily reflect the policy positions of Oxfam and IIED. The views expressed are those of the authors and not necessarily those of Oxfam or IIED.

For more information, or to comment on this report, email jthorpe@oxfam.org.uk

(C) Oxfam International December 2012

This publication is copyright but the text may be used free of charge for the purposes of advocacy, campaigning, education, and research, provided that the source is acknowledged in full. The copyright holder requests that all such use be registered with them for impact assessment purposes. For copying in any other circumstances, or for re-use in other publications, or for translation or adaptation, permission must be secured and a fee may be charged. E-mail policyandpractice@oxfam.org.uk.

The information in this publication is correct at the time of going to press.

Published by Oxfam GB for Oxfam International under ISBN 978-1-78077-228-8 in December 2012. Oxfam GB, Oxfam House, John Smith Drive, Cowley, Oxford, OX4 2JY, UK.

\section{OXFAM}

Oxfam is an international confederation of 17 organizations networked together in 94 countries, as part of a global movement for change, to build a future free from the injustice of poverty. Please write to any of the agencies for further information, or visit www.oxfam.org.

\section{WwW.oxfam.org}

\section{IIED}

The International Institute for Environment and Development is one of the world's top policy research organisations working in the field of sustainable development. With its broad-based network of partners, IIED is helping to tackle the biggest issues of our times - from climate change and cities to the pressures on natural resources and the forces shaping global markets.

Shaping Sustainable Markets is the flagship research project for the Sustainable Markets Group at the International Institute for Environment and Development (IIED).

Can markets be 'governed' to better benefit people and planet? This project explores the individual and combined impact of market governance mechanisms on sustainable development to find out what works where and why. Some of these mechanisms are well established. Others are innovative ideas yet to be tested in the real world.

We want to improve and broaden understanding of how market governance mechanisms can be designed and used to secure livelihoods and protect environments. Find out more about our work at http://shapingsustainablemarkets.iied.org

\section{www.iied.org}
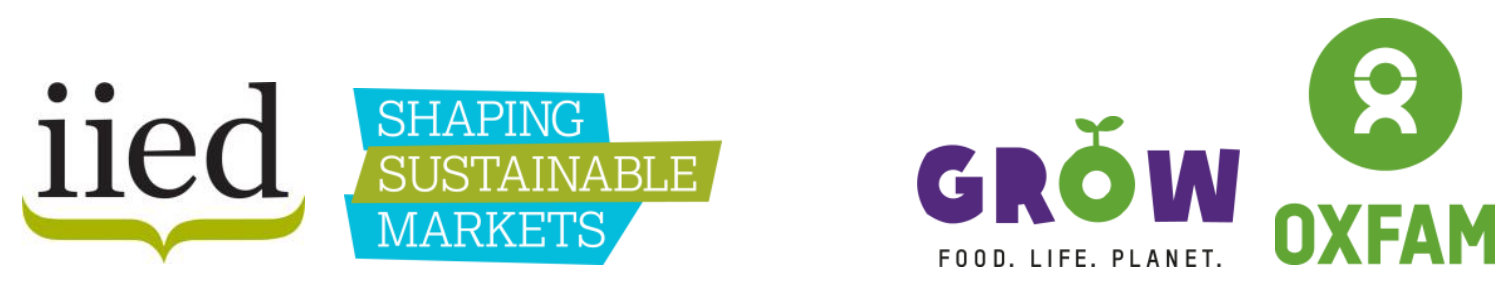